
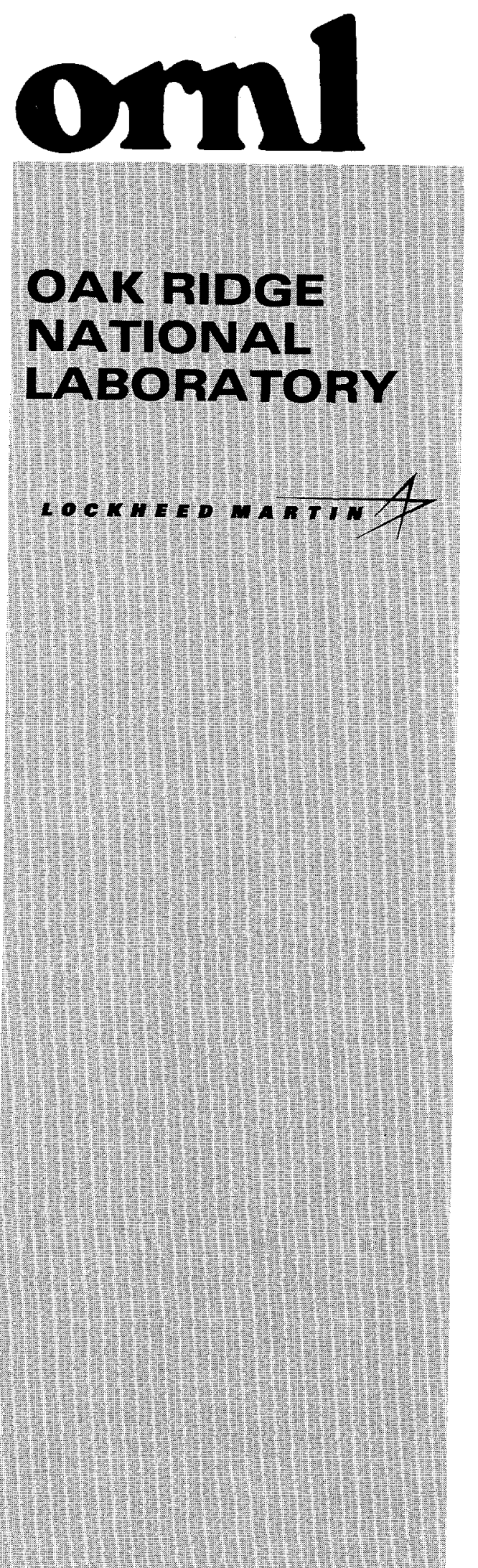

MANAGED AND OPERATED BY

LOCKHEED WARMN ENERGY RESEARCH CORPORATION FOA THE UNTEOSTATES

DEPARTMENT OF IUERGY
EXECUTIVE ORDER 12941 IMPLEMENTATION AT THE OAK RIDGE NATIONAL LABORATORY

K. E. Shaffer

R. J. Kroon

R. J. Hunt

RECEIVED

MAR O 31999

OSTI

August 1998

Prepared by the Center for Natural Phenomena Engineering Oak Ridge Y-12 Plant Oak Ridge, Tennessee 37831-8218

Prepared for the Oak Ridge National Laboratory managed by LOCKHEED MARTIN ENERGY RESEARCH, INC. Oak Ridge, Tennessee 37831-6285 for the U.S. DEPARTMENT OF ENERGY under contract DE-AC05-96OR22464 


\section{DISCLAIMER}

This report was prepared as an account of work sponsored by an agency of the United States Government. Neither the United States Government nor any agency thereof, nor any of their employees, make any warranty, express or implied, or assumes any legal liability or responsibility for the accuracy, completeness, or usefulness of any information, apparatus, product, or process disclosed, or represents that its use would not infringe privately owned rights. Reference herein to any specific commercial product, process, or service by trade name, trademark, manufacturer, or otherwise does not necessarily constitute or imply its endorsement, recommendation, or favoring by the United States Government or any agency thereof. The views and opinions of authors expressed herein do not necessarily state or reflect those of the United States Government or any agency thereof. 


\section{DISCLAIMER}

Portions of this document may be illegible in electronic image products. Images are produced from the best available original document. 


\title{
EXECUTIVE ORDER 12941 IMPLEMENTATION AT THE OAK RIDGE NATIONAL LABORATORY
}

\author{
K. E. Shaffer \\ R. J. Kroon \\ R. J. Hunt
}

August 1998

Prepared by the

Center for Natural Phenomena Engineering

Oak Ridge Y-12 Plant

Oak Ridge, Tennessee 37831-8218

\author{
Prepared for the \\ Oak Ridge National Laboratory \\ managed by \\ LOCKHEED MARTIN ENERGY RESEARCH, INC. \\ Oak Ridge, Tennessee 37831-6285 \\ for the \\ U.S. DEPARTMENT OF ENERGY \\ under contract DE-AC05-96OR22464
}




\section{CONTENTS}

LIST OF APPENDICES $\ldots \ldots \ldots \ldots \ldots \ldots \ldots \ldots \ldots \ldots \ldots$

LIST OF TABLES $\ldots \ldots \ldots \ldots \ldots \ldots \ldots \ldots \ldots \ldots \ldots \ldots \ldots$

EXECUTIVE SUMMARY $\ldots \ldots \ldots \ldots \ldots \ldots \ldots \ldots \ldots \ldots$

REFERENCES ........................ ix

ACRONYMS $\ldots \ldots \ldots \ldots \ldots \ldots \ldots \ldots \ldots \ldots \ldots \ldots \ldots \ldots \ldots \ldots \ldots$

1. SCREENING PROCESS $\ldots \ldots \ldots \ldots \ldots \ldots \ldots \ldots \ldots \ldots \ldots \ldots \ldots \ldots$

1.1 SCREENING OF LEASED AND OWNED BUILDINGS $\ldots \ldots \ldots \ldots \ldots \ldots$

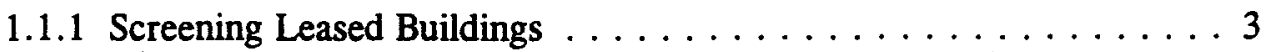

1.1.1.1 Exempt Leased Buildings . . . . . . . . . . . 3

1.1.1.2 Non-Exempt Leased Buildings . . . . . . . . . 3

1.1.2 Screening Owned Buildings . . . . . . . . . . . 4

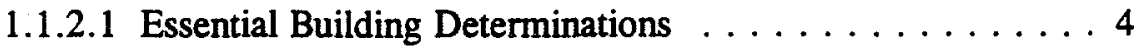

1.1.2.1.1 Non-Essential Buildings $\ldots \ldots \ldots \ldots \ldots$

1.1.2.1.2 Essential Buildings $\ldots \ldots \ldots \ldots \ldots \ldots$

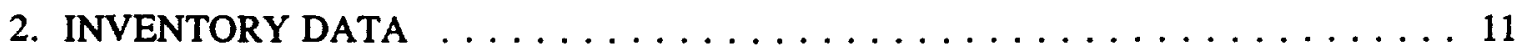

2.1 SEISMICITY ASSIGNMENT $\ldots \ldots \ldots \ldots \ldots \ldots \ldots \ldots \ldots \ldots \ldots$

2.2 BUILDINGS OUTSIDE OF THE MODEL BUILDING TYPES $\ldots \ldots \ldots \ldots 11$

2.3 FOUNDATION TYPE DISCUSSION $\ldots \ldots \ldots \ldots \ldots \ldots \ldots$

3. SELECTION OF BUILDINGS TO BE EVALUATED $\ldots \ldots \ldots \ldots \ldots \ldots$

3.1 DNR BUILDING IDENTIFICATION $\ldots \ldots \ldots \ldots \ldots \ldots \ldots$



3.2.1 Building Ranking . . . . . . . . . . . . . . . . . . . 13

3.2.1.1 EHR Determination for Individual Building . . . . . . 16

3.3 REPRESENTATIVE SAMPLE OF BUILDING TYPE $\ldots \ldots \ldots \ldots \ldots$

3.4 BUILDINGS SELECTED FOR EVALUATION $\ldots \ldots \ldots \ldots \ldots \ldots$

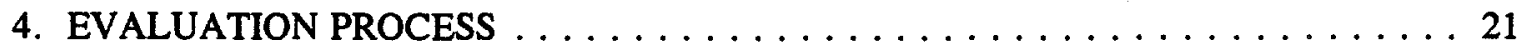

4.1 EVALUATION METHODS $\ldots \ldots \ldots \ldots \ldots \ldots \ldots \ldots \ldots \ldots \ldots \ldots \ldots$

4.2 EVALUATION RESULTS $\ldots \ldots \ldots \ldots \ldots \ldots \ldots \ldots \ldots \ldots \ldots \ldots$

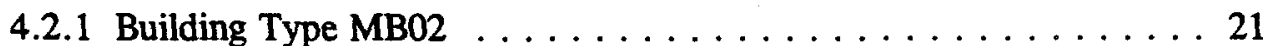

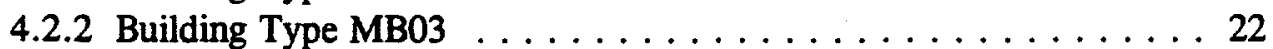

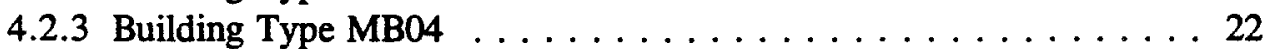



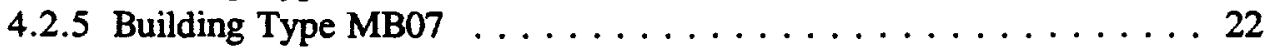

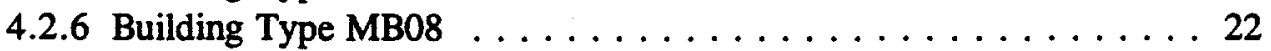

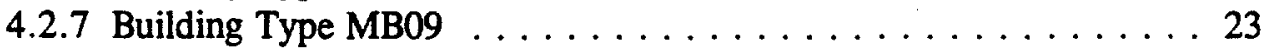

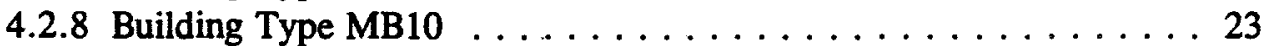




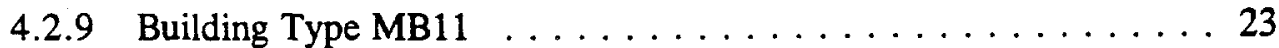



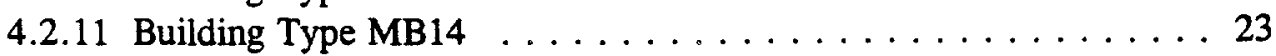

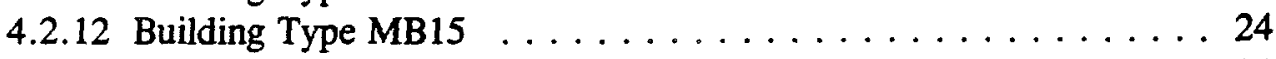

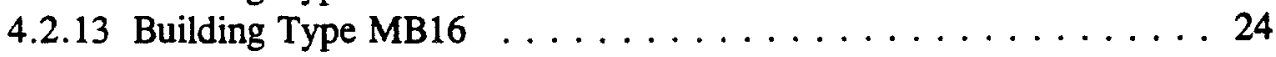

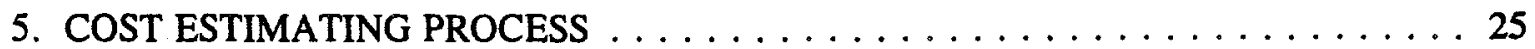

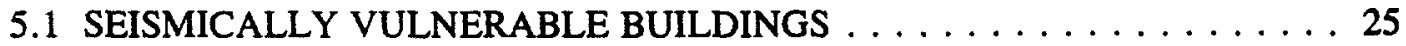

5.2 SEISMICALLY VULNERABLE, NON-EVALUATED BUILDINGS $\ldots \ldots 25$

6. COSTS OF REHABILITATING NON-EVALUATED BUILDINGS . . . . . . . . 27

6.1 ESTIMATED COSTS OF ESSENTIAL, NON-EVALUATED BUILDINGS . 27

6.2 ESTIMATED COSTS OF NON-ESSENTIAL, NON-EVALUATED BUILDINGS

7. COSTS OF REHABILITATING LEASED BUILDINGS $\ldots \ldots \ldots \ldots \ldots$

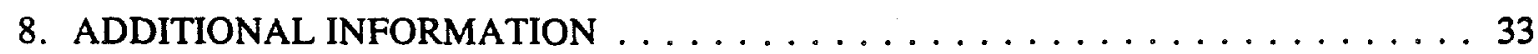

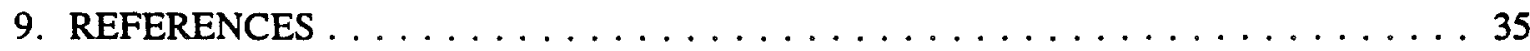




\title{
LIST OF APPENDICES
}

\author{
APPENDIX A. \\ ORNL LEASED BUILDINGS \\ APPENDIX B. \\ INITIAL BUILDING LIST - ORNL \\ APPENDIX C. \\ ORNL EXEMPT BUILDINGS \\ APPENDIX D. \\ ORNL NON-EXEMPT, NON-EVALUATED BUILDINGS \\ APPENDIX E. \\ ORNL EVALUATED, NON-EXEMPT BUILDINGS
}

\section{LIST OF TABLES}

Table 1-1. DOE Classifications of Building Category $\ldots \ldots \ldots \ldots \ldots$

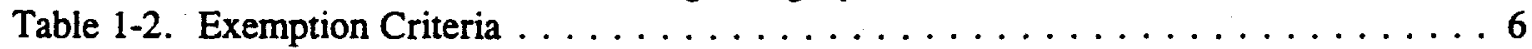

Table 1-3. Number of Exempt ORNL Owned Buildings by Exemption Code $\ldots \ldots \ldots$. . 7

Table 1-4. Model Building Types . . . . . . . . . . . . . . . . 8

Table 1-5. Number of Non-Exempt ORNL Owned Buildings by Model Building Code, Excluding DNR Model Building Type

Table 3-1. Hazard Category Definitions and Scores . . . . . . . . . . . . . 15

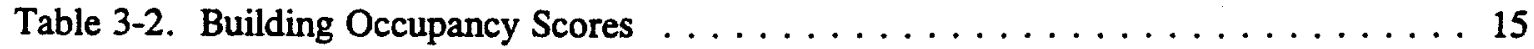

Table 3-3. Building Vulnerability Definitions $\ldots \ldots \ldots \ldots \ldots \ldots \ldots$

Table 3-4. Risk Ranking Determination $(\mathrm{RK}=\mathrm{FC} \times \mathrm{BV}) \ldots \ldots \ldots \ldots \ldots$

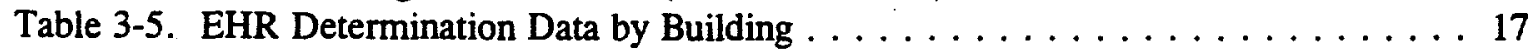

Table 3-6. Evaluation Strategy for ORNL Non-Exempt Model Building Type . . . . . . . 19

Table 6-1. Estimated Costs for Essential, Non-Evaluated Buildings . . . . . . . . . . 28

Table 6-2. Estimated Costs for Non-Essential, Non-Evaluated Buildings . . . . . . . 30 
This page intentionally left blank. 


\section{EXECUTIVE SUMMARY}

Congress enacted the Earthquake Hazards Reduction Act of 1977 (Public Law 95-124, as amended) to reduce risks to life and property from future earthquakes in the United States. To implement the provisions of the Act, the Interagency Committee on Seismic Safety in Construction (ICSSC) was chartered. Approximately thirty Federal agencies, including the Department of Energy (DOE), participate in the ICSSC. The ICSSC is chaired by the National Institute of Standards (NIST) which also provides the technical secretariat.

Executive Order (EO) 12699, Seismic Safety of Federal and Federally Assisted or Regulated New Building Construction, and EO 12941, Seismic Safety of Existing Federally Owned or Leased Buildings, were prepared and issued by the ICSSC to reduce the vulnerability to buildings owned or leased by agencies or departments for Federal use. EO 12699 and EO 12941 were signed January 5, 1990 and December 1, 1994, respectively (ICSSC 1990 and ICSSC 1994a). As stipulated in the Orders, the Federal Emergency Management Agency (FEMA) is responsible for the implementation of EO 12699 and EO 12941. NIST, via the ICSSC, provides technical assistance to Federal agencies or departments for the implementation of the requirements of EO 12699 and EO 12941. The ICSSC also prepared ICSSC RP 5/NISTR 5374, ICSSC Guidance on Implementing Executive Order 12941 on Seismic Safety of Existing Federally Owned or Leased Buildings and ICSSC TR-17/NISTR 5770, How-To Suggestions for Implementing Executive Order 12941 on Seismic Safety of Existing Federal Buildings, A Handbook to facilitate the implementation of EO 12941 (ICSSC 1995a and ICSSC 1995b).

The goals of EO 12941 are to develop inventories of Federally owned buildings, identify vulnerable buildings within the inventories, and prepare cost estimates for rehabilitating these buildings. The inventory and cost estimate information collected will be used to develop reliable information for developing future national public policy for mitigating seismic risk of vulnerable buildings within the Federal inventory.

Inventory and cost estimate data collected across the DOE complex will be compiled, consolidated, and forwarded to FEMA in December 1998. By December 2000, FEMA will have submitted to Congress a complete Federal inventory and cost estimate. For purposes of EO 12941, a building is defined as any structure, fully or partially enclosed, located within the United States, used or intended for sheltering persons or property. Exceptions to the definition of a building are described in ICSSC RP 4/NISTR 5382, Standards of Seismic Safety for Existing Federally Owned or Leased Buildings and Commentary (ICSSC 1994b).

To expedite the implementation of EO 12941 across the DOE complex, the Seismic Safety Working Group (SSWG) was established and the Management Plan for the Implementation of Executive Order 12941 was prepared and issued (DOE 1996). The DOE management plan incorporates and considers guidance in RP 4, RP 5, and TR-17 and provides additional DOEspecific guidance for implementing EO 12941 at it's sites.

This report documents the implementation of EO 12941 at the Oak Ridge National Laboratory (ORNL) in Oak Ridge, Tennessee. ORNL is managed and operated by Lockheed Martin Energy 
Research, Inc. (LMER) for the DOE-Oak Ridge Operations Office (DOE-ORO). The ORNL building inventory includes buildings that are physically located at ORNL, East Tennessee Technology Park (ETTP), and the Oak Ridge Y-12 Plant. This report addresses buildings physically located at the ORNL plant site. ORNL buildings located at ETTP and Y-12 plant sites will be included in the EO 12941 implementation reports for those sites. The scope of this effort included revising the building inventory for ORNL that was prepared prior to the development of the DOE management plan, evaluating owned buildings not exempt from the requirements of EO 12941, estimating the costs associated with the rehabilitation of vulnerable non-exempt buildings, and preparing this report in the TR-17 prescribed format (CNPE 1996). These activities were performed in accordance with the DOE management plan and as applicable, Phase I - Screening Guidelines To Determine The Structures Exempt From Executive Order 12941 (CNPE 1995).

At ORNL, there are six contractor (LMER) leased buildings and 528 DOE owned buildings. By direction from DOE, contractor leased buildings are discussed in this report but no evaluations were performed. One of the contractor leased buildings were determined to be exempt from the requirements of EO 12941. The balance of the leased buildings, five, are considered non-exempt. Appendix A fulfills the inventory requirements for the leased buildings. Of the 528 owned buildings, 367 were determined, through a screening process, to be exempt from the requirements of EO 12941. One hundred sixty-one owned buildings were found to be non-exempt. Appendices $\mathrm{C}, \mathrm{D}$, and $\mathrm{E}$ to the report fulfill the inventory requirements for owned buildings at the ORNL site.

The 161 non-exempt buildings, were evaluated to determine if there were any Exceptionally High Risk (EHR) or Definitely Needing Rehabilitation (DNR) buildings at ORNL. To identify EHR buildings, seismicity, structural system, building function, number of occupants, and criticality to mission are some of the factors that are considered. Buildings identified as EHR are representative of a higher priority action to be considered in the public policy development activities for mitigating seismic risk after the year 2000. In areas of Moderate seismicity such as Oak Ridge, it is expected that 0.5 to $1.0 \%$ of the total building inventory will fall in the EHR category. DNR is defined as those buildings that are so obviously in need of rehabilitation that they do not need further evaluation to determine that rehabilitation efforts are needed. Buildings identified as DNR do not require further evaluation while EHR buildings are required to be fully evaluated. There is one DNR building at ORNL, building 1506, and two EHR buildings, $4500 \mathrm{~N}$ and 4500 S.

A representative sample of each building type of the non-exempt buildings were evaluated. At ORNL, there are 13 different building types including the building types representative of the DNR (1506) and EHR (4500N and 4500S) buildings. One evaluation was performed during this effort. Building 1506 was evaluated to confirm the DNR classification. To minimize the cost of the evaluations, previous seismic analyses for the same building type were used whenever possible. Previous evaluations used to support the this effort include the Turnpike Building in Oak Ridge, TN, buildings K-601, K-731, K-1001, K-1004-A, K-1037, K-1401, K-1423, K-1435-C, K-1650, and K-1654-A at ETTP, building 3025E at ORNL, and buildings $\mathrm{C}-300$ and $\mathrm{C}-720-\mathrm{K}$ at the Paducah Gaseous Diffusion Plant, Paducah, KY. Ongoing evaluations of 3019A, 3019B, and 7920 at ORNL were also considered to fulfill the requirements of the evaluation phase.

Of the buildings evaluated or reviewed, the following twenty-nine buildings were found to be 
seismically vulnerable.

$\begin{array}{llll}1000 & 3038 & 5000 & 7569 \\ 1504 & 3105 & 5500 & 7830 \\ 1506(\text { DNR) } & 3500 & 5506 & 7834 \\ 2010 & 4500 \mathrm{~N}(\text { EHR) } & 6000 \mathrm{~B} & 7852 \\ 2026 & 4500 \text { S (EHR) } & 6003 & 7931 \\ 2537 & 4501 & 6010 & \\ 3009 & 4508 & 6025 & \\ 3037 & 4515 & 7567 & \end{array}$

The buildings identified in this report as being vulnerable to seismic events do not pose any greater risk to building occupants or to the general public than any other building population of similar size in the eastern United States. Seismic rehabilitation of buildings at this time is not required unless the function of the building has changed which increases the level of use, importance, or occupancy, the useful life of the building is extended more than $50 \%$ of it's replacement value through modifications or alterations, or the building has been damaged by events such as earthquakes, fire, wind, or other cause. Programs to fully mitigate the identified vulnerable buildings will be developed by FEMA and Congress after December 2000.

Rehabilitation cost estimates were prepared using FEMA-156, Second Edition, Typical Costs for Seismic Rehabilitation of Existing Buildings, Volume 1-Summary, and FEMA-157, Second Edition, Typical Costs for Seismic Rehabilitation of Buildings, Volume II - Supporting Documentation, and DOE specific guidance issued after this report was issued in November 1997 (FEMA 1994 and 1995, DOE 1998a and DOE 1998b). Chapter 5, Cost Estimating Process, describes the process to derive rehabilitation cost estimates. The cost estimates for evaluated and non-evaluated buildings are summarized in Appendix $E$ and Tables 6-1 and 6-2, respectively. The total estimated cost for rehabilitating ORNL is $\$ 34,777,300$ in 1998 dollars. The estimated rehabilitation cost of the DNR building, 1506, has been estimated in 1998 dollars as approximately $\$ 302,800$. The estimated rehabilitation costs in 1998 dollars for the EHR buildings, $4500 \mathrm{~N}$ and $4500 S$ are $\$ 11,890,300$ and $\$ 9,563,100$, respectively.

This revision incorporates revised cost estimates in accordance with current DOE cost estimating. 
This page intentionally left blank. 


\section{REFERENCES}

Center for Natural Phenomena Engineering. September 1995. Phase I-Screening Guidelines To Determine The Structures Exempt From Executive Order 12941, ES/CNPE-95/4, Lockheed Martin Energy Systems, Inc., Oak Ridge, TN.

Center for Natural Phenomena Engineering. April 1996. Phase I-Screening to Determine Structures Exempt from Executive Order 12941 at the Oak Ridge National Laboratory, ES/CNPE96/2, Lockheed Martin Energy Systems, Inc., Oak Ridge, TN.

Federal Emergency Management Agency. December 1994. Second Edition, Typical Costs for Seismic Rehabilitation of Existing Buildings, Volume 1 - Summary, FEMA-156, Washington, D.C.

Federal Emergency Management Agency. June 1995. Second Edition, Typical Costs for Seismic Rehabilitation of Buildings, Volume II - Supporting Documentation, FEMA-157, Washington, D.C.

Interagency Committee on Seismic Safety. January 1990. Seismic Safety of Federal and Federally Assisted or Regulated New Building Construction, Executive Order 12699, National Institute of Standards and Technology, Gaithersburg, MD.

Interagency Committee on Seismic Safety. January 1994a. Seismic Safety of Existing Federally Owned or Leased Buildings, Executive Order 12941, National Institute of Standards and Technology, Gaithersburg, MD.

Interagency Committee on Seismic Safety. February 1994b. Standards of Seismic Safety for Existing Federally Owned or Leased Buildings and Commentary, ICSSC RP 4/NISTR 5382, National Institute of Standards and Technology, Gaithersburg, MD.

Interagency Committee on Seismic Safety. October 1995a. ICSSC Guidance on Implementing Executive Order 12941 on Seismic Safety of Existing Federally Owned or Leased Buildings, ICSSC RP 5/NISTR 5734, National Institute of Standards and Technology, Gaithersburg, MD.

Interagency Committee on Seismic Safety. November 1995b. How-To Suggestions for Implementing Executive Order 12941 on Seismic Safety of Existing Federal Buildings, A Handbook, ICSSC TR-17/NISTR 5770, National Institute of Standards and Technology, Gaithersburg, MD.

Office of Nuclear Safety Policy and Standards. November 1996. Management Plan for the Implementation of Executive Order 12941, Department of Energy, Washington, D.C.

Office of Nuclear Safety Policy and Standards. July 1998a. Implementation of Executive Order (E.O.) 12941 for Seismic Safety of Existing Buildings and Update on NPH Issues, Department of Energy, Washington, D.C. 
Office of Nuclear Safety Policy and Standards. July 1998b. Implementation of Executive Order (E.O.) 12941 for Seismic Safety of Existing Buildings, Department of Energy, Washington, D.C. 


\section{ACRONYMS}

$\begin{array}{ll}\text { BO } & \text { Building Occupancy } \\ \text { BV } & \text { Building Vulnerability } \\ \text { CAS } & \text { Condition Assessment Survey } \\ \text { DOE } & \text { Department of Energy } \\ \text { DOE-ORO } & \text { Department of Energy-Oak Ridge Operations } \\ \text { DNR } & \text { Definitely Needing Rehabilitation } \\ \text { EO } & \text { Executive Order } \\ \text { EHR } & \text { Exceptionally High Risk } \\ \text { ETTP } & \text { East Tennessee Technology Park } \\ \text { FC } & \text { Failure Consequence } \\ \text { FEMA } & \text { Federal Emergency Management Agency } \\ \text { FIMS } & \text { Facilities Information Management System (U. S. Department of Energy) } \\ \text { GSA } & \text { General Services Administration } \\ \text { HC } & \text { Hazard Category } \\ \text { HH } & \text { High Hazard } \\ \text { ICSSC } & \text { Interagency Committee on Safety in Seismic Construction } \\ \text { LMER } & \text { Lockheed Martin Energy Research, Inc. } \\ \text { LH } & \text { Low Hazard } \\ \text { MH } & \text { Moderate Hazard } \\ \text { NEHRP } & \text { National Earthquake Hazards Reduction Program } \\ \text { NPH } & \text { National Phenomena Hazards } \\ \text { ORNL } & \text { Oak Ridge National Laboratory } \\ \text { PC } & \text { Performance Category } \\ \text { PGDP } & \text { Paducah Gaseous Diffusion Plant } \\ \text { RK } & \text { Risk Ranking } \\ \text { RP } & \text { Recommended Practice } \\ \text { SAR } & \text { Safety Analysis Report } \\ \text { SSWG } & \text { Seismic Safety Working Group } \\ & \end{array}$




\section{SCREENING PROCESS}

As stated in Executive Order (EO) 12941, any agency that owns or leases buildings for Federal use is required to develop by December 1, 1998 seismic inventories of their owned and leased buildings and cost estimates for mitigating unacceptable seismic risks to those inventories (ICSSC 1994a). To ensure that all agencies consistently evaluate and mitigate seismic hazards for their building inventories, the Interagency Committee on Safety in Seismic Construction (ICSSC) prepared and issued ICSSC RP 4/NISTR 5382, Standards of Seismic Safety for Existing Federally Owned or Leased Buildings and Commentary (ICSSC 1994b). RP 4 was adopted by EO 12941 as the standard for assessing seismic safety. Substantial life-safety is the minimum acceptable performance objective as defined in RP 4. The ICSSC also prepared ICSSC RP 5/NISTR 5374, ICSSC Guidance on Implementing Executive Order 12941 on Seismic Safety of Existing Federally Owned or Leased Buildings and ICSSC TR-17/NISTR 5770, How-To Suggestions for Implementing Executive Order 12941 on Seismic Safety of Existing Federal Buildings, A Handbook, to facilitate the implementation of EO 12941 (ICSSC 1995a and ICSSC 1995b).

For purposes of EO 12941, a building is defined as any structure, fully or partially enclosed, located within the United States, used or intended for sheltering persons or property, except for the exclusions described in RP 4.

Each agency owning or leasing buildings are required by EO 12941 to submit to the Federal Emergency Management Agency (FEMA) their inventories, cost estimates, and supporting documentation by December 1, 1998. RP 5 and TR-17 provide the reporting and inventory formats to be used. The inventories (databases) are also to be submitted electronically to FEMA by this date. Agencies that own and lease buildings will develop two separate inventories, one for owned buildings and one for leased buildings.

The Department of Energy (DOE) is a Federal agency that both leases and owns buildings. To expedite the implementation of EO 12941 across the Department of Energy (DOE) complex, the Seismic Safety Working Group (SSWG) was established and the Management Plan for the Implementation of Executive Order 12941 was prepared and issued (DOE 1996c). The DOE management plan incorporates and considers guidance in RP 4, RP 5, and TR-17 and provides additional DOE-specific guidance for implementing EO 12941 at it's sites.

\subsection{SCREENING OF LEASED AND OWNED BUILDINGS}

The flowchart illustrated in Fig. 1-1 depicts the DOE screening process for leased and owned buildings. From the figure, the starting point for the screening activities is an initial building inventory for the site. To develop the initial building inventory, the agency may elect to use any property inventory strategy in place for a complete listing of their buildings. For DOE locations, the Facilities Information Management System (FIMS) and the Condition Assessment Survey (CAS) program are good starting points for developing a comprehensive inventory for a particular site. 


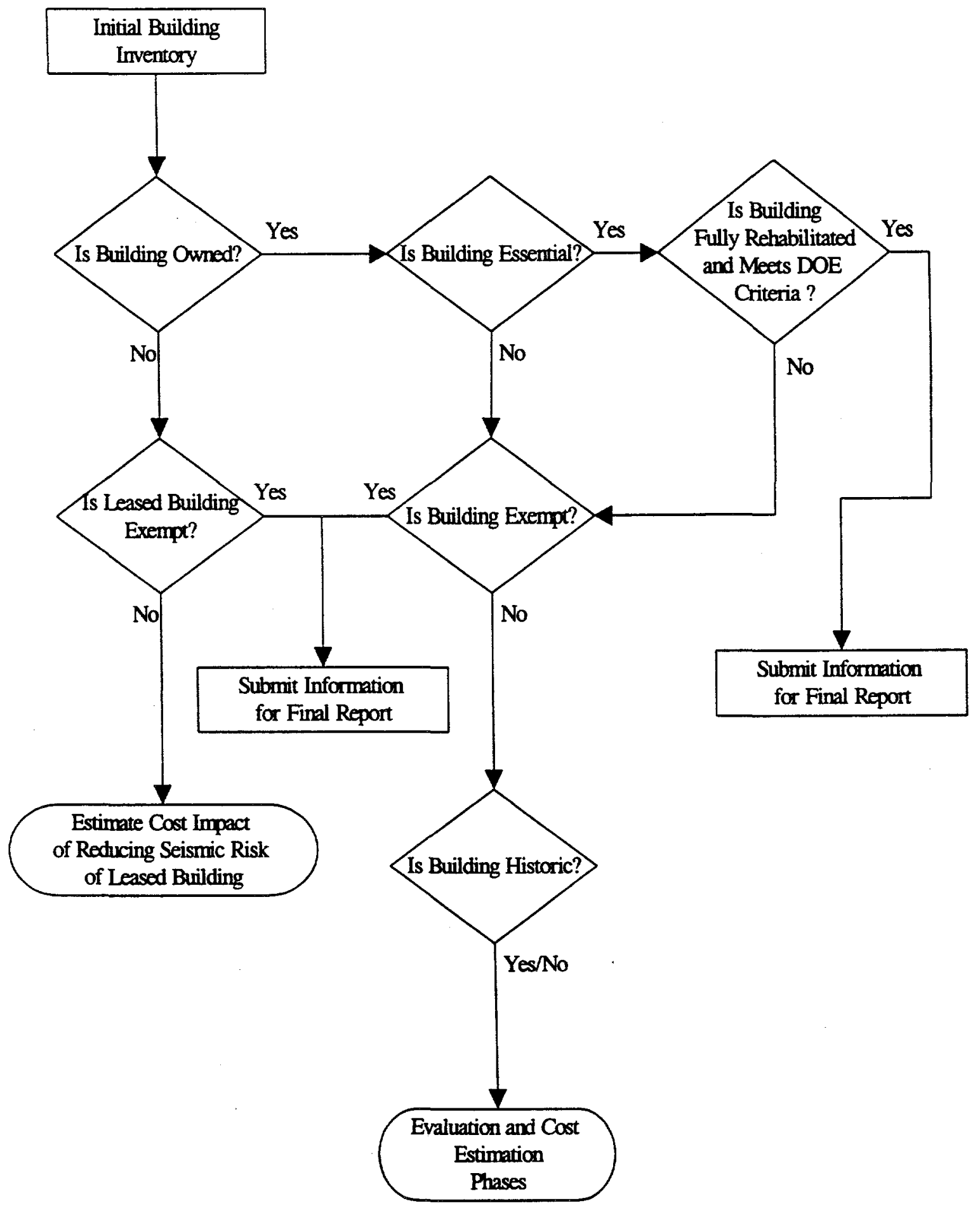

Fig. 1-1. Screening Flowchart for DOE Leased and Owned Buildings 
Once leased versus owned determinations have been made, additional screening activities are to be applied to help identify high risk, high priority owned buildings. The decision boxes shown in Fig. 1-1 represent the screens to be applied to the leased and owned inventories and the actions to be undertaken pending the outcome of the screen. The terminator boxes at the bottom of the Fig. 1-1 indicate the next phases of the implementation of EO 12941.

The leased and owned buildings at the Oak Ridge National Laboratory (ORNL) in Oak Ridge, Tennessee were screened applying the logic shown in Fig. 1-1. ORNL is managed and operated by Lockheed Martin Energy Research, Inc. (LMER) for the DOE-Oak Ridge Operations Office (DOE-ORO). An initial building inventory for ORNL was previously prepared which utilized FIMS data for the site and a site-specific building directory (CNPE 1996). Six leased and 527 owned buildings were identified and are listed in Appendix A and B, respectively.

\subsubsection{Screening Leased Buildings}

Per RP 4, leased buildings are exempt from the requirements of EO 12941 if the leased space is less than $10,000 \mathrm{ft}^{2}\left(930 \mathrm{~m}^{2}\right)$ and DOE leases less that $50 \%$ of the total building square footage. Conversely, if the leased space is greater than $10,000 \mathrm{ft}^{2}$ and DOE leases more than $50 \%$ of the total building square footage, then the building is considered non-exempt. If the non-exempt building does not meet DOE seismic safety standards then the lease on the building is not to be renewed. Existing leases may be held without mitigative action until the lease expires.

To fulfill the inventory requirements of EO 12941 for leased buildings, the ICSSC recommends submitting existing DOE lease inventory data to FEMA if the space is not leased from the General Services Administration (GSA) or another Federal agency. DOE is also required to estimate the cost impact of reducing seismic risk in leased buildings and report the findings in supporting documentation.

Currently, there are six buildings leased by LMER for DOE which support the ORNL mission. One contractor leased building, 1060 COMM, was found to be exempt while the balance of the contractor leased buildings, five, were determined to be non-exempt. All leased buildings at ORNL are leased from non-Federal agencies.

\subsubsection{Exempt Leased Buildings}

Building 1060 COMM was found to be exempt because LMER leases less than $10,000 \mathrm{ft}^{2}$ and less than $50 \%$ of the total square footage of the building. No further evaluation of this building is required.

\subsubsection{Non-Exempt Leased Buildings}

There are five non-exempt contractor leased buildings included in the ORNL inventory. Located within the Oak Ridge, TN area are FEDC, 78 MITCHELL, and 101 MID. These buildings comprise more than $50 \%$ of the total square footage of the building and therefore were determined to be non-exempt. There are two buildings, GERMANTOWN, MD and CAPITAL 
GALLERY that are classified as non-exempt due to the lack of information regarding these buildings. An assessment to determine if these five contractor leased buildings meet DOE seismic safety standards has not been performed. Guidance has been provided to the DOE field offices that if the leased buildings do not meet DOE standards then the leases are not to be renewed.

Appendix A to this report satisfies the inventory requirements for the leased buildings at ORNL.

\subsubsection{Screening Owned Buildings}

It is estimated that the Federal government owns close to a half-million buildings. It would be prohibitively costly to collect detailed seismic vulnerability information and rehabilitation cost estimates on the entire Federal government building population. RP 4 defines exemption criteria (screens) to be applied to the owned building inventory to identify those buildings that present an extremely low threat to life-safety (exempt) in the event of an earthquake. The remaining buildings not meeting the RP 4 exemption criteria (non-exempt) are further evaluated to determine seismic risk and mitigation costs.

\subsubsection{Essential Building Determinations}

One of the first screens to be applied to owned buildings is to identify essential buildings. Essential has been defined as those buildings that require seismic resistance higher than life-safety. Buildings meeting the DOE seismic performance category PC2, PC3, or PC4 criteria as defined in DOE-STD-1021-93, Natural Phenomena Hazards Performance Categorization Guidelines for Structures, Systems, and Components and shown in Table 1-1, are considered "essential" for the purposes of the implementation of EO 12941 (DOE 1993). The Building Category Codes noted in Table 1-1 correspond to the performance category criteria designations for the inventory database as described in TR-17 and the DOE management plan.

The Office of Operational Readiness and Facility Safety at ORNL provided the performance category classifications for ORNL buildings. 
Table 1-1. DOE Classifications of Building Category

\begin{tabular}{|c|c|}
\hline 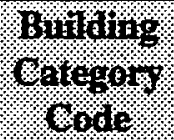 & DOE Performance Eategove Griteria Description \\
\hline P1 & $\begin{array}{l}\text { General use buildings. } \\
\text { (Examples include administrative buildings, cafeterias, storage buildings, } \\
\text { repair shops, etc.) } \\
\text { Note: Equivalent Performance Category Code is PC-1 (Life safety). }\end{array}$ \\
\hline P2 & $\begin{array}{l}\text { Emergency operations centers, hospitals, fire stations and low-hazard } \\
\text { facilities. } \\
\text { (Examples of low-hazard facilities include laboratories and production } \\
\text { facilities) } \\
\text { Note: Equivalent Performance Category Code is PC-2 (Essential). }\end{array}$ \\
\hline P3 & $\begin{array}{l}\text { Buildings that contain significant amounts of hazardous materials that have } \\
\text { potential for major on site impact only. } \\
\text { (For example, uranium enrichment plants) } \\
\text { Note: Equivalent Performance Category Code is PC-3 (Essential). }\end{array}$ \\
\hline P4 & $\begin{array}{l}\text { Buildings that contain significant amounts of hazardous materials that have } \\
\text { potential for major impacts off site. } \\
\text { (For example, nuclear reactors) } \\
\text { Note: Equivalent Performance Category Code is PC-4 (Essential). }\end{array}$ \\
\hline
\end{tabular}

\subsection{Non-Essential Buildings}

Non-essential buildings, or buildings meeting the DOE PC1 performance category criteria (exempt), are further screened using the RP 4 exemption criteria defined in Table 1-2. The Exemption Codes correspond to the exemption code designations for the inventory database as described in TR-17. 
Table 1-2. Exemption Criteria

\begin{tabular}{|c|c|}
\hline Womprion. & Brenution \\
\hline E0 & Building is not exempt. \\
\hline E1 & $\begin{array}{l}\text { Building is classified for agricultural use, or intended only for incidental } \\
\text { human occupancy, or occupied by persons for a total of less than } 2 \text { hours a } \\
\text { day. }\end{array}$ \\
\hline E2 & $\begin{array}{l}\text { Building is a detached one- or two-family dwelling located in an area having a } \\
\text { governing acceleration coefficient less than } 0.15 \mathrm{~g} \text {. }\end{array}$ \\
\hline E3 & $\begin{array}{l}\text { Building is a one-story building of steel light frame or wood construction with } \\
\text { an area of less than } 280 \mathrm{~m}^{2}(3,000 \text { square feet). }\end{array}$ \\
\hline E4 & $\begin{array}{l}\text { The building has been fully rehabilitated to comply with the RP } 4 \text { seismic } \\
\text { safety standards in all four compliance categories (structural, nonstructural, } \\
\text { geologic/site hazards, and adjacency). }\end{array}$ \\
\hline E5 & $\begin{array}{l}\text { The building is a post-benchmark building as defined in Table } 1 \text { of RP } 4 \\
\text { which also complies with the nonstructural, geologic/site, and adjacency } \\
\text { categories. }\end{array}$ \\
\hline E6 & $\begin{array}{l}\text { The building is a pre-benchmark building which has been shown by } \\
\text { evaluation to be life-safe in all four compliance categories. }\end{array}$ \\
\hline E7 & $\begin{array}{l}\text { The building was constructed for the Federal government and the detailed } \\
\text { design was done after the date of the adoption of Executive Order } 12699 \\
\text { (January 5, 1990) and the building was designed and constructed in } \\
\text { accordance with ICSSC Guidelines and Procedures for Implementation of the } \\
\text { Executive Order on Seismic Safety of New Building Construction. }\end{array}$ \\
\hline E8 & $\begin{array}{l}\text { The remaining useful life of the building has been identified as being less than } \\
\text { five years. }\end{array}$ \\
\hline E9 & $\begin{array}{l}\text { Other. This exemption code is also to be used for: special structures, } \\
\text { including but not limited to: bridges, transmission towers, industrial towers } \\
\text { and equipment, piers and wharves, and hydraulic structures; leased buildings } \\
\text { identified as exempt in accordance with RP } 4 \text { and Federally permitted or } \\
\text { regulated privately owned buildings on Federal land. }\end{array}$ \\
\hline
\end{tabular}


There are 367 exempt buildings at ORNL. Table 1-3 summarizes the number of exempt owned buildings at the ORNL by exemption code.

Table 1-3. Number of Exempt ORNL Owned Buildings by Exemption Code

\begin{tabular}{|c|c|}
\hline 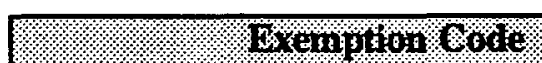 & 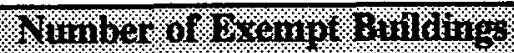 \\
\hline E1 & 154 \\
\hline E3 & 198 \\
\hline$\overline{E 5}$ & 1 \\
\hline \begin{tabular}{|r|r} 
\\
\end{tabular} & 14 \\
\hline
\end{tabular}

Not included in Table 1-3 or in the total building population reported in this report (528) are those facilities that should be classified as Other Structures and Facilities but are in the ORNL FIMS database as buildings. Since these facilities do not meet the definition of a building as defined in EO 12941, they have not been included in this report. In the ORNL FIMS database these facilities will be shown as having an E9 exemption.

Appendix $C$ summarizes and fulfills the exempt, owned inventory database requirements for ORNL.

\subsection{Essential Buildings}

Essential buildings, those buildings meeting the PC2 or greater performance category criteria (non-exempt), must be further evaluated to determine whether the building is fully rehabilitated and meets DOE seismic performance criteria, whether it is historic, or whether the building should be classified as Definitely Needing Rehabilitation (DNR) or Exceptionally High Risk (EHR). In accordance with RP 5, TR-17, and the DOE management plan, the balance of the owned buildings, 161 non-exempt buildings, were evaluated to determine if there were any DNR or EHR buildings at ORNL. There is one DNR building, building 1506, and two EHR buildings, $4500 \mathrm{~N}$ and $4500 \mathrm{~S}$, at ORNL.

Buildings that do not meet DOE seismic performance criteria, are not historic, and are not classified as DNR or EHR are sorted by building type and a representative from each building type is selected for further evaluation. Table $1-4$ lists the model building types and the Model Building Codes to be included in the inventory database. The Model Building Codes noted in Table 1-4 correspond to the model building type designations for the inventory database as described in TR17. 
Table 1-4. Model Building Types

\begin{tabular}{|c|c|}
\hline 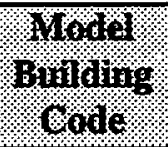 & Hode $\%$ Bullings Yos \\
\hline MB01 & Wood Light Frame \\
\hline MBO2 & Wood, Commercial and Industrial \\
\hline MB03 & Steel Moment Frame \\
\hline MB04 & Steel Braced Frame \\
\hline MB05 & Steel Light Frame \\
\hline MB06 & Steel Frame with Concrete Shear Walls \\
\hline MB07 & Steel Frame with Infill Shear Walls \\
\hline MB08 & Concrete Moment Frame \\
\hline MB09 & Concrete Shear Walls \\
\hline MB10 & Concrete Frame with Infill Shear Walls \\
\hline MB11 & Precast/Tilt-up Concrete Walls with Lightweight Flexible Diaphragm \\
\hline MB12 & Precast Concrete Frames with Concrete Shear Walls \\
\hline MB13 & Reinforced Masonry Bearing Walls with Wood or Metal Deck Diaphragms \\
\hline MB14 & Reinforced Masonry Bearing Walls with Precast Concrete Diaphragms \\
\hline MB15 & Unreinforced Masonry Bearing Wall Buildings \\
\hline MB16 & Other - describe briefly in Field 23 and in the supporting documentation. \\
\hline
\end{tabular}

The balance of the non-exempt buildings less the number of DNR buildings, 160 , were sorted by building type to identify a representative sample and to determine the number of seismic evaluations that needed to be performed. Buildings classified as DNR do not require evaluation while EHR buildings are required to be evaluated. At ORNL, there are 12 different building types including the building type representative of the EHR buildings ( $4500 \mathrm{~N}$ and $4500 \mathrm{~S}$ are MB08) and excluding the DNR model building type (MB11). Table 1-5 summarizes the number of non-exempt owned buildings at ORNL by model building type. 
Table 1-5. Number of Non-Exempt ORNL Owned Buildings by Model Building Code, Excluding DNR Model Building Type

\begin{tabular}{|c|c|}
\hline . & Noder Buildiug Code \\
\hline MB02 & 12 \\
\hline MB03 & 43 \\
\hline MB04 & 22 \\
\hline MB05 & 12 \\
\hline MB07 & 4 \\
\hline MB08 & 8 \\
\hline MB09 & 8 \\
\hline MB10 & 8 \\
\hline MB13 & 14 \\
\hline MB14 & 8 \\
\hline MB15 & 19 \\
\hline MB16 & 2 \\
\hline & \\
\hline & \\
\hline & \\
\hline
\end{tabular}

Appendices D and E summarize the non-exempt, owned information for ORNL and fulfills the inventory requirements for ORNL. 
This page intentionally left blank. 


\section{INVENTORY DATA}

In addition to the building specific inventory data collected in the Chap. 1, Screening Process, additional data related to the site and the buildings are required. This chapter discusses assigning buildings to seismicity categories, buildings that did not fit in the 15 model building types, and foundation types that do not correspond to the foundation types categories as described in TR-17.

Appendix $C$ fulfills the requirements for the inventory database for exempt, owned buildings at ORNL. Appendices D and E satisfy the inventory requirements for the non-exempt, owned buildings and includes data obtained during the evaluation phase for the evaluated buildings.

\subsection{SEISMICITY ASSIGNMENT}

All buildings at ORNL were assigned the seismicity category of Moderate corresponding to the state and county location seismicity values obtained from TR-17 and Table A-1, Location and Seismicity Data.

\subsection{BUILDINGS OUTSIDE OF THE MODEL BUILDING TYPES}

At ORNL, two buildings were identified outside of the 15 model building types noted in Table 14, Model Building Types. Buildings 5500 and 6010 were assigned a building type "Other" or $\mathrm{MB} 16$ because these buildings cannot be categorized as having one predominant building type. Building $\mathbf{5 5 0 0}$ has both concrete moment frame and steel braced frame building systems (MB08 and MB04, respectively). Approximately $75 \%$ of 5500 is MB08. Building 6010 is approximately $50 \%$ steel braced frame and unreinforced masonry bearing walls (MB04 and MB15, respectively). "Two Building Systems" has been added to the Comment field for each of these buildings in the inventory database.

\subsection{FOUNDATION TYPE DISCUSSION}

As discussed in TR-17 the foundation types for non-exempt buildings that are evaluated are to be included in the inventory. The foundation types listed in TR-17 are shallow foundations (isolated or continuous spread footings or mats), deep (piles or piers) and other. At ORNL, the foundation types are classified as shallow and a FT1 designation assigned per TR-17. 
This page intentionally left blank. 


\section{SELECTION OF BUILDINGS TO BE EVALUATED}

At the conclusion of the screening and inventory phases and the elimination of leased and exempt owned buildings, the buildings to be evaluated were identified and are discussed in the following sections.

\subsection{DNR BUILDING IDENTIFICATION}

To determine whether there are any DNR buildings at ORNL, the guidelines included in RP 5 were considered. Per RP 5, the following building type examples can be designated as DNR.

- unreinforced masonry buildings in areas of high seismicity

- concrete frame buildings without shear walls built before 1960 in areas of high seismicity

- $\quad$ pre-cast frame buildings in moderate and high seismic areas

There is one building at ORNL, 1506, that is a pre-cast frame building and is categorized as a DNR building. It has been given a model building type designation of MB11 in Appendix E.

\subsection{EHR BUILDING IDENTIFICATION}

The approach undertaken at ORNL to identify EHR buildings is as depicted in Fig. 3-1.

\subsubsection{Building Ranking}

DOE has developed a prioritization process to screen out buildings of low seismic vulnerability and to direct initial detailed evaluation and mitigation efforts to the buildings which are at greatest potential seismic risk. Two attributes are assigned for each non-exempt building. The product of these attributes represents the total score for the building. The buildings with the highest final scores represent those buildings with the highest seismic vulnerability.

Existing hazard category (HC) and building occupancy (BO) information for each building is considered. Numerical values for both $\mathrm{HC}$ and $\mathrm{BO}$ are defined in Tables 3-1 and 3-2, respectively. The higher of the two scores is the FC score. 


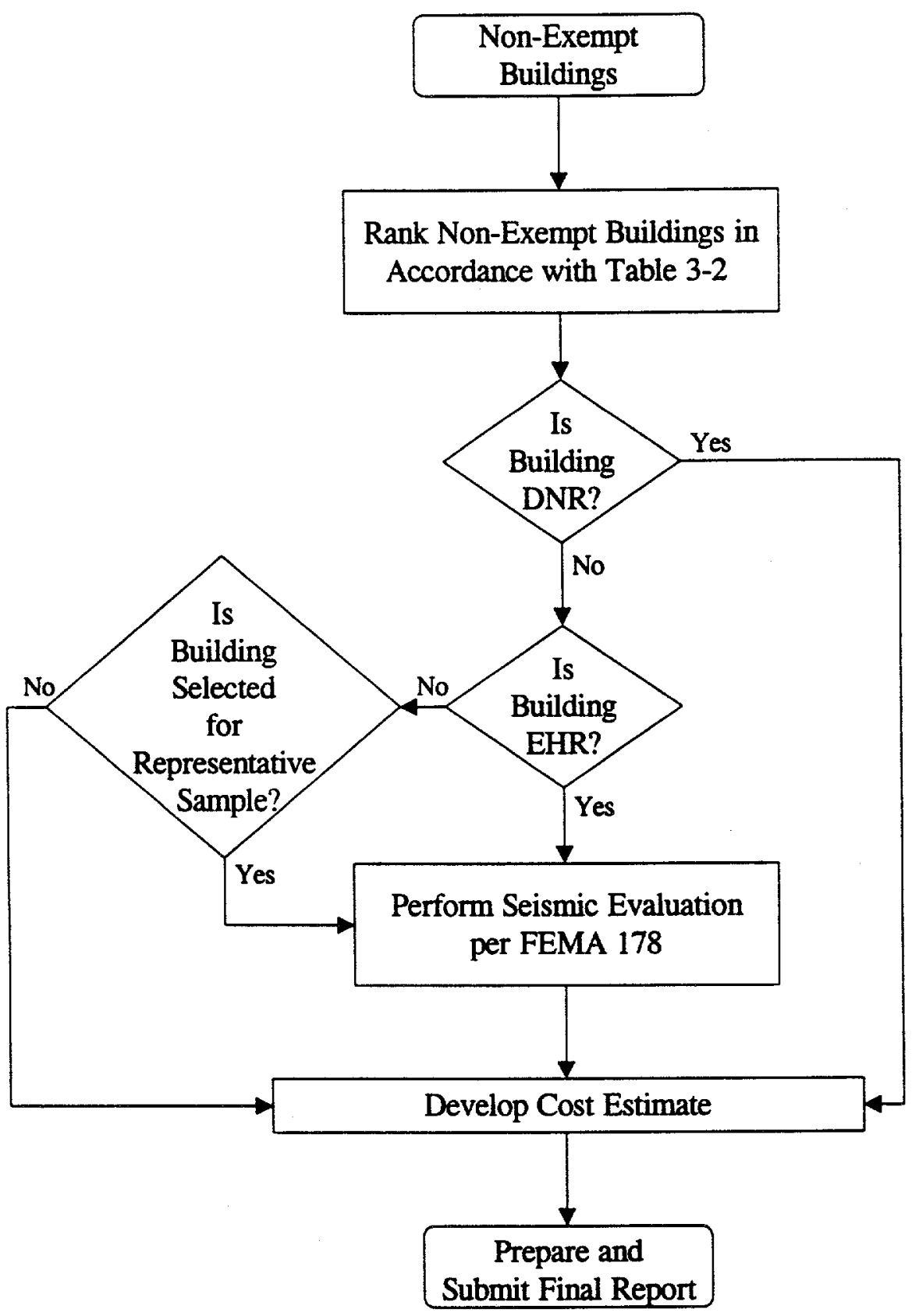

Fig. 3-1. Evaluation Methodology and Approach 
Table 3-1. Hazard Category Definitions and Scores

\begin{tabular}{|c|c|c|}
\hline Horard Sategoy (WC) & Bofnifion & 800 re \\
\hline $\mathrm{HCl}$ or $\mathrm{HH}$ & $\begin{array}{l}\text { Potential for significant offsite } \\
\text { radiological or chemical hazard. }\end{array}$ & 10 \\
\hline $\mathrm{HC} 2$ or $\mathrm{MH}$ & $\begin{array}{l}\text { Potential for significant onsite } \\
\text { radiological or chemical hazard. }\end{array}$ & 3 \\
\hline $\mathrm{HC} 3$ or $\mathrm{LH}$ & $\begin{array}{l}\text { Potential for localized or minor } \\
\text { radiological or chemical hazard } \\
\text { or a facility with essential } \\
\text { services which must survive the } \\
\text { seismic event. }\end{array}$ & 1 \\
\hline Other & General usage facility. & 0 \\
\hline
\end{tabular}

Table 3-2. Building Occupancy Scores

\begin{tabular}{|c|c|}
\hline Building Occupancy $($ BO) & $8001 \%$ \\
\hline $300+$ Occupants & 10 \\
\hline 51-300 Occupants & 6 \\
\hline 6-50 Occupants & 3 \\
\hline$<6$ Occupants & 0 \\
\hline
\end{tabular}

The second attribute is the Building Vulnerability (BV). This attribute is based on the condition of the building in relation to the seismic hazard at the site of the building. The ranking approach is based on assigning the condition of the building as good, fair, poor, or very poor. This qualification is based as much as possible on existing information. Where existing seismic structural analyses have been completed, the ranking is based on the ratio of the seismic capacity to the seismic demand of critical structural members (seismic capacity/demand ratio). Table 3-3 provides a correlation between the seismic capacity/demand ratio and building condition. If there is insufficient existing analysis, the condition of the building should be evaluated using data on building behavior of past earthquakes. To establish the condition of the building, the preliminary evaluation checklists found in FEMA-178, NEHRP Handbook for the Seismic Evaluation of Existing Buildings is allowed (FEMA 1992). 
Table 3-3. Building Vulnerability Definitions

\begin{tabular}{|c|c|}
\hline Seismic Capacity Denrand Ratio & Brallating Condilion \\
\hline 20.9 & Good \\
\hline $20.7<0.9$ & Fair \\
\hline $20.5<0.7$ & Poor \\
\hline$<0.5$ & Very Poor \\
\hline
\end{tabular}

The Risk Ranking (RK) is then determined from Table 3-4, below.

Table 3-4. Risk Ranking Determination $(\mathrm{RK}=\mathbf{F C} \times \mathbf{B V})$



\subsubsection{EHR Determination for Individual Building}

To determine if there were any EHR buildings at ORNL, the non-exempt buildings with the highest building occupancy (BO) were considered, Table 3-5. The hazard classification (HC) for these buildings, as determined during the essential building screening, are General Usage and Moderate Hazard (HC scores equal to 0 and 3, respectively). Building vulnerabilities were then considered. For example, building 1001 is a two-story wood structure and the building condition is considered poor on the basis of an evaluation of a similar building at ETTP (CNPE 1997a). 
Building 1000 received a BV score of 42 , as read from Table 3-4. This process was repeated for the rest of the buildings in Table 3-5. Table 3-5 summarizes by building, $\mathrm{BO}$ and corresponding $\mathrm{BV}$ values.

Table 3-5. EHR Determination Data by Building

\begin{tabular}{|c|c|c|c|}
\hline 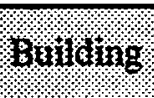 & 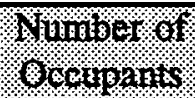 & 80. & ory \\
\hline 1000 & 225 & 6 & 42 \\
\hline 1505 & 207 & 6 & 0 \\
\hline 2001 & 104 & 6 & 0 \\
\hline 2500 & 100 & 6 & 0 \\
\hline 3147 & 160 & 6 & 0 \\
\hline 3500 & 187 & 6 & 42 \\
\hline $4500 \mathrm{~N}$ & 878 & 10 & 70 \\
\hline $4500 S$ & 693 & 10 & 70 \\
\hline 4508 & 157 & 6 & 42 \\
\hline 5500 & 162 & 6 & 42 \\
\hline
\end{tabular}

From Table 3-5, buildings $4500 \mathrm{~N}$ and $4500 \mathrm{~S}$ were classified as EHR because their BV scores were greater than 60 .

\subsection{REPRESENTATIVE SAMPLE OF BUILDING TYPE}

After identifying exceptionally high risk buildings for evaluation, a representative sample of the remaining non-exempt buildings are to be evaluated. One to two percent of the non-exempt buildings will provide an adequate representative sample at sites with large inventories $(>1000$ non-exempt buildings). However, in the case of ORNL (161 non-exempt buildings), a $2 \%$ sampling would result in a sample of three buildings for evaluation. Since there is not one correct way to choose a representative sample, an evaluation of a representative building from each of the 12 non-exempt building types, excluding the DNR model building type, was performed. FEMA178 guidelines was used for non-exempt buildings meeting the DOE performance category criteria of PC1. DOE-STD-1020-94, Natural Phenomena Hazards Design and Evaluation Criteria for Department of Energy Facilities, will be used for non-exempt buildings meeting the performance category criteria for PC2, PC3, and PC4 (DOE 1996a). At the completion of the evaluations, the 
remaining buildings in that building type will be compared to the evaluated building. Buildings within the building type judged to respond differently than the evaluated building may require additional evaluation.

Evaluations may consist of actual FEMA-178 or DOE-STD-1020-94 analyses or review of existing evaluations to determine if the evaluation criteria used is substantially equivalent to the criteria called out in FEMA-178. Due to the similarities between ORNL, ETTP, and the Paducah Gaseous Diffusion Plant (PGDP), Paducah, Kentucky, PGDP and ETTP analyses will also be considered.

The goal of these evaluations is to determine whether the building type is seismically vulnerable or not through a consistent evaluation approach.

\subsection{BUILDINGS SELECTED FOR EVALUATION}

There are 13 model building types in the non-exempt inventory at ORNL. To reduce the cost of building evaluations, buildings previously evaluated to criteria substantially equivalent to the RP 4 minimum evaluation procedure (FEMA-178), is allowed as described in TR-17 and reiterated in the DOE management plan. For DOE essential non-exempt buildings (PC-2, PC-3 and PC-4) the more stringent DOE-STD-1020-94, Natural Phenomena Hazards Design and Evaluation Criteria for Department of Energy Facilities, will be used (DOE 1996a). As suggested in TR-17, previousiy evaluated buildings meeting the minimum evaluation criteria should be included in the evaluated sample.

To further economize, representative samples of non-exempt buildings within the same model building type at the East Tennessee Technology Park (ETTP), Oak Ridge, Tennessee, the Oak Ridge Y-12 Plant (Y-12), Oak Ridge, Tennessee, and the Paducah Gaseous Diffusion Plant (PGDP), Paducah, Kentucky, that exhibit similar structural characteristics were extrapolated to ORNL non-exempt buildings. ETTP, ORNL, PGDP, and Y-12 are all located in a Moderate seismic zone.

The following structural characteristics were considered when extrapolating a representative sample from the ETTP, PGDP, and Y-12 sites to ORNL.

- Model Building Type - one-to-one extrapolation from the same model building type

- Building Layout - regular configuration versus irregular configuration

- Building Height

- Number of Above Ground Stories

- $\quad$ Building Stiffness and Weight

- Equipment Weight and Equipment Weight Distribution

- Area, $\mathrm{ft}^{2}$

- Date of Construction

- Earthquake Ground Motion Used in the Evaluation of the Building

- Building Foundation Conditions

- Essential Designation (Performance Category Classification) 
- Previous Evaluation Criteria

- Experience with Previous Evaluations

The response analysis for ORNL and the site-specific response spectra for soil equivalent to the response spectra derived from FEMA-178 was used for all evaluation extrapolations (Ahmed, Hunt, \& Manrod 1995).

Based on the above approaches, one building evaluation was performed as part of this effort. Building 1506, model building type MB11, was evaluated to conclusively determine whether this building was a DNR building. Table 3-6 summarizes the strategy for satisfying evaluation requirements for ORNL non-exempt buildings by model building type.

Table 3-6. Evaluation Strategy for ORNL Non-Exempt Model Building Type

\begin{tabular}{|c|c|}
\hline Model Bullding I Ype & Gralinitionstratiegr: \\
\hline $\mathrm{MB02}$ & $\begin{array}{l}\text { Previous Analysis of Turnpike Building and ETTP } \\
\text { EO } 12941 \text { Analysis of K-1001 }\end{array}$ \\
\hline MB03 & Previous ETTP Analysis of K-1401 \\
\hline MB04 & Previous ETTP Analyses of K-1037, K-1423, and K-1650 \\
\hline MB05 & ETTP EO 12941 Analysis of K-1435-C \\
\hline MB07 & Previous ORNL Analysis of 3025E \\
\hline MB08 & ETTP EO 12941 Analysis of K-731 \\
\hline MB09 & Previous PGDP Analysis of C -300 \\
\hline MB10 & ETTP EO 12941 Analysis of K-601 \\
\hline MB11 & EO 12941 Analysis of 1506 \\
\hline MB13 & PGDP EO 12941 Analysis of C-720-K \\
\hline MB14 & ETTP EO 12941 Analysis of K-1654-A \\
\hline MB15 & $\begin{array}{l}\text { ETTP EO } 12941 \text { Analysis of K-1004-A and Ongoing } \\
\text { ORNL Analyses of 3019A, 3019B, and } 7920\end{array}$ \\
\hline MB16 & $\begin{array}{l}\text { Previous ETTP Analysis of K-1037, K-1423, and K-1650, } \\
\text { ETTP EO } 12941 \text { Analysis of K-731, and ETTP EO } 12941\end{array}$ \\
\hline
\end{tabular}


This page intentionally left blank. 


\section{EVALUATION PROCESS}

The buildings identified in Chap. 3, Selection of Buildings to Be Evaluated, have been evaluated and the approach and results will be discussed in detail in this Chapter.

\subsection{EVALUATION METHODS}

For DOE buildings, the evaluation approach outlined in FEMA-178 was used for PC1 buildings while DOE-STD-1020-94 was used for the PC2 and PC3 buildings at ORNL. The FEMA-178 approach is designed to determine the potential earthquake-related risk to building occupants (life-safety). DOE-STD-1020-94 utilizes a graded approach and provides evaluation criteria for PC2 and PC3 buildings to meet life-safety, continued operation, and hazard confinement objectives.

One building, 1506, was evaluated as part of this effort. Previous ETTP analyses of K-1037, $\mathrm{K}-1401, \mathrm{~K}-1423, \mathrm{~K}-1650$, and the Turnpike Building were reviewed and utilized as well as a previous analysis of PGDP building C-300. EO 12941 evaluations of K-601, K-731, K-1001, K1004-A, K-1435-C, K-1654-A, and C-720-K were also used to complete the evaluation effort.

\subsection{EVALUATION RESULTS}

The results of the evaluations conducted for each model building type are described in the following sections.

\subsubsection{Building Type MB02}

The buildings included in this model building type are one story buildings with the exception of buildings 1001 and 6003 which are two story structures. To satisfy the evaluation requirement for this model building type the results of a FEMA-178 evaluation for ETTP building K-1001 was used for the two story structures and an evaluation of the Turnpike Building was used for the evaluation of the one story structures (CNPE 1997a and Allen \& Hoshall 1991).

Based on the FEMA-178 analysis of K-1001 it was determined that buildings 1000 and 6003 are seismically vulnerable. Rehabilitation cost estimates were prepared for these buildings and are included in Appendix E and Table 6-2, Estimated Costs for Non-Essential, Non-Evaluated Buildings, for buildings 1000 and 6003 , respectively.

There are 10 one story buildings in the MB02 building type. These buildings are sufficiently similar to the Turnpike Building. A previous analysis of the Turnpike Building was available and results extrapolated to these buildings. Based on the evaluation results of the Turnpike Building, it was determined that the one story MB02 buildings were adequate for life-safety. Rehabilitation costs for these buildings were not estimated in this effort. 


\subsubsection{Building Type MB03}

There are $43 \mathrm{MB} 03$ buildings at ORNL. To determine if MB03 buildings are seismically vulnerable, a previous analysis of building K-1401 at ETTP was reviewed and the results extrapolated to ORNL (CNPE 1997a). This review indicates that life-safety is adequately provided in the non-exempt buildings within the MB03 building type. Rehabilitation cost estimates for this building type were not prepared as part of this effort.

\subsubsection{Building Type MB04}

There are $22 \mathrm{MB} 04$ buildings at ORNL. To assess the life-safety of the ORNL buildings in the MBO4 category, previous analyses of ETTP buildings K-1037, K-1423, and K-1650 were reviewed. These reviews indicate that life-safety is adequately provided in the non-exempt buildings within MB04 (CNPE 1997a). Rehabilitation cost estimates for this building type were not prepared.

\subsubsection{Building Type MB05}

Twelve steel light frame buildings were identified as non-exempt at ORNL. This model building type includes pre-engineered or prefabricated buildings and are typically relatively small in size. DOE seismic performance categories PC1, PC2, and PC3 are represented in this model building type. Building K-1435-C at ETTP was evaluated using DOE-STD-1020-94 criteria and was found to be to provide adequate life-safety (CNPE 1997a). MB05 buildings at ORNL were judged to be similar in construction to $\mathrm{K}-1435-\mathrm{C}$ and are therefore are adequate for life-safety. Rehabilitation cost estimates were not prepared for this model building type.

\subsubsection{Building Type MB07}

There are four buildings at ORNL that are classified as MB07. These buildings are constructed with steel frames and infill shear walls. A previous analysis of building 3025E was performed in support of the safety analysis report (SAR) effort at ORNL and was found to adequately meet DOE-STD-1020-94 criteria for a PC2 facility (ORNL 1997). Since the remainder of the MB07 buildings (3025W, 4505, and 4507) at ORNL are PC1 facilities, it has been determined these buildings are seismically adequate based on the $3025 \mathrm{E}$ evaluation. Rehabilitation cost estimates were not prepared for this model building type.

\subsubsection{Building Type MB08}

The primary lateral load carrying system of this building type are concrete moment frames. This construction type is no longer permitted in Moderate seismic zones. There are eight MB08 non-exempt buildings at ORNL. Included in these eight MB08 buildings are buildings $4500 \mathrm{~N}$ and $4500 \mathrm{~S}$ which were determined to be EHR per the determination described in Sect. 3.2, EHR Building Identification. A FEMA-178 evaluation of ETTP building K-731 was performed and the results demonstrated that K-731 is seismically vulnerable (CNPE 1997a). The amount of shear reinforcement supplied was less than that required by FEMA-178 criteria. Rehabilitation cost estimates were prepared for this building type. The rehabilitation cost estimates for $4500 \mathrm{~N}$ and 
4500S are included in Appendix E. The cost estimates for the remainder of the MB08 are included in Tables 6-1 and 6-2.

\subsubsection{Building Type MB09}

There are eight MB09 buildings at ORNL. Building C-300 was evaluated at PGDP and the results of the evaluation extrapolated for use at ORNL (CNPE 1997b). All MB09 buildings at ORNL were found to be adequate for life-safety. Rehabilitation cost estimates were not prepared as part of this effort.

\subsubsection{Building Type MB10}

Model building type MB10 are characterized by reinforced concrete frames with infill shear walls. ETTP building K-601 was evaluated and found to be adequate for life-safety (CNPE 1997a). The ORNL buildings in this building type are similar in construction to K-601 and are judged to be adequate for life-safety. Rehabilitation cost estimates were not prepared as part of this effort.

\subsubsection{Building Type MB11}

This building type is characterized as a precast/tilt-up concrete wall with a lightweight flexible diaphragm. There is one building at ORNL that is constructed in this manner, building 1506 . A FEMA-178 evaluation was performed to ensure that the DNR designation was correct for this building type in a Moderate seismic area. The results of the evaluation conclude that the DNR classification is correct and that building 1506 is seismically vulnerable. A rehabilitation cost estimate was prepared as part of this effort and is included in Appendix E.

\subsubsection{Building Type MB13}

There are 13 non-exempt MB13 buildings at ORNL. PGDP building C-720-K was evaluated as part of the EO 12941 implementation effort at that site and is used to complete the evaluation requirements at ORNL (CNPE 1997b). The results of the PGDP evaluation demonstrate that MB13 type buildings are capable of providing life-safety to it's occupants as long as the bar joists are anchored to the reinforced masonry walls. Bar joists are anchored to the masonry walls at ORNL and, therefore, the MB13 provide adequate life-safety. No rehabilitation cost estimates for this model building type were prepared.

\subsubsection{Building Type MB14}

There are eight non-exempt MB14 buildings at ORNL. A FEMA-178 evaluation of ETTP building K-1654-A was performed as part of the EO 12941 implementation at that site and is suitable for use at ORNL (CNPE 1997a). The K-1654-A building was found to be adequate for life-safety and, therefore, all MB14 buildings at ORNL are seismically adequate. No rehabilitation cost estimates were performed for this model building type. 


\subsubsection{Building Type MB15}

To assess the adequacy of life-safety of this building type, ETTP building K-1004-A was evaluated using DOE-STD-1020-94 criteria and found to be seismically vulnerable (CNPE 1997a). The weak link was the lack of a positive connection between the roof and walls. In addition to the evaluation of K-1004-A, ORNL buildings 3019A, 3019B, and 7920 are currently being evaluated in support of the SAR efforts for these buildings. Building 3019A, 3019B, and 7920 because of these evaluations are adequate for life-safety. The remainder of the MB15 building types are seismically vulnerable on the basis of the K-1004-A evaluation. Rehabilitation cost estimates for this model building type are included in Tables 6-1 and 6-2 with the exception of building 3019A, 3019B, and 7920 .

\subsubsection{Building Type MB16}

There are two buildings at ORNL that are characterized as MB16. Buildings 5500 and 6010 each have dual systems that could not be categorized as predominantly one building type or another. These buildings have been given a building type of "Other" or MB16. Building 5500 is comprised of MB04 and MB08 building systems while building 6010 is comprised of MBO4 and MB15 systems. MB04 has been determined to be adequate for life-safety. Since 5500 has a MB08 building system and 6010 has a MB15 system and both building systems have been determined to be seismically vulnerable, rehabilitation costs for these portions of their building systems have been estimated and are included in Table 6-2. 


\section{COST ESTIMATING PROCESS}

The cost estimating process for evaluated, non-exempt and non-evaluated, non-exempt buildings at ORNL is described in this Chapter.

\subsection{SEISMICALLY VULNERABLE BUILDINGS}

For each evaluated building found to be seismically vulnerable, rehabilitation costs in four categories are to be estimated. Structural, non-structural, finishing, and project costs. Structural costs are costs associated with changes to the lateral force resisting system. Non-structural costs are costs associated with changes to other parts of the building and to building equipment, systems, and contents. Finishing costs are costs associated with removing and replacing finishes such as wallboard, paint, carpet, etc. Project costs are costs associated with design, testing, permit fees, cost of project management, etc.

Rehabilitation cost estimates were prepared using FEMA-156, Second Edition, Typical Costs for Seismic Rehabilitation of Existing Buildings, Volume 1 - Summary, and FEMA-157, Second Edition, Typical Costs for Seismic Rehabilitation of Buildings, Volume II - Supporting Documentation, and DOE specific guidance issued after this report was issued in November 1997 (FEMA 1994 and 1995, DOE 1998a and DOE 1998b). Estimated costs for each of the above categories for each of the evaluated buildings at ORNL are included in Appendix E. A code of C3 has been entered for the Source of Cost Estimate to refer to Option 2 cost estimating method used for deficient, evaluated buildings at ORNL.

A time adjustment factor of 1.10 was used for all cost estimates based on 1998 dollars. An inflation rate of $2 \%$ from the 1993 cost estimates in FEMA-156 and FEMA-157 was assumed. A thirty percent adjustment factor for project costs was used per guidance issued by NIST.

The estimated cost of rehabilitating seismically vulnerable, evaluated buildings at ORNL is $\$ 22,825,100$.

\subsection{SEISMICALLY VULNERABLE, NON-EVALUATED BUILDINGS}

Rehabilitation cost estimates for seismically vulnerable, non-evaluated buildings were prepared for each building in accordance with the guidance documents referenced in Sect. 5.1, Seismically Vulnerable Buildings. Cost estimates for those portions of the MB16 building types at ORNL that are seismically vulnerable were also prepared.

The estimated cost of rehabilitating seismically vulnerable, non-evaluated buildings at ORNL is $\$ 11,952,200$. 
This page intentionally left blank. 


\section{COSTS OF REHABILITATING NON-EVALUATED BUILDINGS}

This Chapter provides the estimated costs as described in Chap. 5, Cost Estimating Process, for non-evaluated, seismically vulnerable buildings. As described in TR-17, costs associated with non-evaluated historic, essential, and all others are to be reported. ORNL has two historic buildings within in it's inventory. However, one of the historic buildings was exempt from the requirements of EO 12941 and the other historic building is categorized as a model building type that provides adequate seismic safety. Therefore, rehabilitation cost estimates for historic buildings are not included in the following discussion. Only essential and non-essential building types at ORNL will be reported in this Chapter.

\subsection{ESTIMATED COSTS OF ESSENTIAL, NON-EVALUATED BUILDINGS}

Table 6-1 summarizes, by model building type, the cost estimates in each of the four cost categories for essential, non-evaluated buildings at ORNL including the vulnerable portions of the MB16 buildings. 
Table 6-1. Estimated Costs for Essential, Non-Evaluated Buildings

\begin{tabular}{|c|c|c|c|c|c|c|c|c|c|c|c|}
\hline \multirow{3}{*}{$\begin{array}{c}\text { Seismicity } \\
\text { Area }\end{array}$} & \multirow{3}{*}{$\begin{array}{l}\text { No. of } \\
\text { Bldgs. }\end{array}$} & \multirow{3}{*}{$\begin{array}{c}\text { Area, } \\
\mathbf{m}^{2}\end{array}$} & \multicolumn{9}{|c|}{ Estimated Costs } \\
\hline & & & \multicolumn{4}{|c|}{ Cost per Square Meter } & \multicolumn{5}{|c|}{ Total Cost } \\
\hline & & & $\begin{array}{c}\text { Structural } \\
\text { Costs, } \\
\$ / \mathbf{m}^{2}\end{array}$ & $\begin{array}{c}\text { Non- } \\
\text { Structural } \\
\text { Costs, } \\
\$ \mathbf{m}^{2}\end{array}$ & $\begin{array}{c}\text { Finishing } \\
\text { Costs, } \\
\$ / \mathrm{m}^{2}\end{array}$ & $\begin{array}{c}\text { Project } \\
\text { Costs, } \\
\$ / \mathbf{m}^{2}\end{array}$ & $\begin{array}{c}\text { Structural } \\
\text { Costs, } \$\end{array}$ & $\begin{array}{c}\text { Non- } \\
\text { Structural } \\
\text { Costs, } \$\end{array}$ & $\begin{array}{l}\text { Finishing } \\
\text { Costs, \$ }\end{array}$ & $\begin{array}{l}\text { Project } \\
\text { Costs, \$ }\end{array}$ & $\begin{array}{c}\text { Total } \\
\text { Costs, } \$\end{array}$ \\
\hline Moderate & 11 & 7026 & 292.70 & 28.14 & 28.14 & 104.68 & 2056500 & 197700 & 197700 & 735500 & 3187400 \\
\hline
\end{tabular}




\subsection{ESTIMATED COSTS OF NON-ESSENTIAL, NON-EVALUATED BUILDINGS}

Table 6-2 summarizes, by model building type, the cost estimates in each of the four cost categories for non-essential, non-evaluated buildings at ORNL including the vulnerable portions of the MB16 buildings. 
Table 6-2. Estimated Costs for Non-Essential, Non-Evaluated Buildings

\begin{tabular}{|c|c|c|c|c|c|c|c|c|c|c|c|}
\hline \multirow{3}{*}{$\begin{array}{c}\text { Model } \\
\text { Building } \\
\text { Type }\end{array}$} & \multirow{3}{*}{$\begin{array}{l}\text { No. of } \\
\text { Bldgs. }\end{array}$} & \multirow{3}{*}{$\begin{array}{c}\text { Area, } \\
\mathbf{m}^{2}\end{array}$} & \multicolumn{9}{|c|}{ Estimated Costs } \\
\hline & & & \multicolumn{4}{|c|}{ Cost per Square Meter } & \multicolumn{5}{|c|}{ Total Cost } \\
\hline & & & $\begin{array}{c}\text { Structural } \\
\text { Costs, } \\
\$ / \mathrm{m}^{2}\end{array}$ & $\begin{array}{c}\text { Non- } \\
\text { Structural } \\
\text { Costs, } \\
\$ \mathbf{m}^{\mathbf{2}}\end{array}$ & $\begin{array}{c}\text { Finishing } \\
\text { Costs, } \\
\$ / \mathbf{m}^{2}\end{array}$ & $\begin{array}{c}\text { Project } \\
\text { Costs, } \\
\$ / \mathbf{m}^{2}\end{array}$ & $\begin{array}{c}\text { Structural } \\
\text { Costs, } \$\end{array}$ & $\begin{array}{c}\text { Non- } \\
\text { Structural } \\
\text { Costs, } \$\end{array}$ & $\begin{array}{c}\text { Finishing } \\
\text { Costs, } \$\end{array}$ & $\begin{array}{l}\text { Project } \\
\text { Costs, } \$\end{array}$ & $\begin{array}{c}\text { Total } \\
\text { Costs, } \$\end{array}$ \\
\hline MB02 & 1 & 681 & 84.76 & 18.36 & 18.36 & 7.05 & 57800 & 12500 & 12500 & 24800 & 107600 \\
\hline MB08 & 5 & 27292 & 145.30 & 18.32 & 18.32 & 54.59 & 3965600 & 500000 & 500000 & 1489800 & 6455400 \\
\hline MB15 & 8 & 11803 & 106.84 & 18.33 & 18.33 & 43.04 & 1261000 & 216400 & 216400 & 508000 & 2201800 \\
\hline
\end{tabular}




\section{COSTS OF REHABILITATING LEASED BUILDINGS}

There are six contractor leased buildings included in the ORNL building inventory. Five of these buildings are non-exempt from the requirements of EO 12941. Evaluation of the non-exempt leased buildings are not required. As directed to the DOE field offices, if the leased space does not meet DOE seismic safety standards, then the lease is not to be renewed. The cost impact of rehabilitating leased buildings was not estimated for LMER leased buildings. 
This page intentionally left blank. 


\section{ADDITIONAL INFORMATION}

No additional information is provided. 
This page intentionally left blank. 


\section{REFERENCES}

S. B. Ahmed, R. J. Hunt, W. E. Manrod, III. September 1995. Y-12 Site-Specific Earthquake Response Analysis and Soil Liquefaction Assessment, Y/EN-5444, Lockheed Martin Energy Systems, Inc., Oak Ridge, TN.

Allen \& Hoshall, Inc. January 1991. Natural Phenomena Hazards Evaluation, Buildings 2714, 2715, \& Turnpike Building, Knoxville, TN.

Center for Natural Phenomena Engineering. April 1996. Phase I-Screening to Determine Structures Exempt from Executive Order 12941 at the Oak Ridge National Laboratory, ES/CNPE96/2, Lockheed Martin Energy Systems, Inc., Oak Ridge, TN.

Center for Natural Phenomena Engineering. November 1997a. Executive Order 12941 Implementation at the East Tennessee Technology Park, ES/CNPE-97/4, Lockheed Martin Energy Systems, Inc., Oak Ridge, TN.

Center for Natural Phenomena Engineering. November 1997b. Executive Order 12941 Implementation at the Paducah Gaseous Diffusion Plant, ES/CNPE-97/3, Lockheed Martin Energy Systems, Inc., Oak Ridge, TN.

Department of Energy. January 1996a. Natural Phenomena Hazards Design and Evaluation Criteria for Department of Energy Facilities, DOE-STD-1020-94, Change Notice \#1, Washington, D.C.

Department of Energy. January 1996b. Natural Phenomena Hazards Performance Categorization Guidelines for Structures, Systems, and Components, DOE-STD-1021-94, Change Notice \#1, Washington, D.C.

Federal Emergency Management Agency. June 1992. NEHRP Handbook for the Seismic Evaluation of Existing Buildings, FEMA-178, Washington, D.C.

Federal Emergency Management Agency. December 1994. Second Edition, Typical Costs for Seismic Rehabilitation of Existing Buildings, Volume 1 - Summary, FEMA-156, Washington, D.C.

Federal Emergency Management Agency. June 1995. Second Edition, Typical Costs for Seismic Rehabilitation of Buildings, Volume II - Supporting Documentation, FEMA-157, Washington, D.C.

Interagency Committee on Seismic Safety. January 1994a. Seismic Safety of Existing Federally Owned or Leased Buildings, Executive Order 12941, National Institute of Standards and Technology, Gaithersburg, MD.

Interagency Committee on Seismic Safety. February 1994b. Standards of Seismic Safety for Existing Federally Owned or Leased Buildings and Commentary, ICSSC RP 4/NISTR 5382, 
National Institute of Standards and Technology, Gaithersburg, MD.

Interagency Committee on Seismic Safety. October 1995a. ICSSC Guidance on Implementing Executive Order 12941 on Seismic Safety of Existing Federally Owned or Leased Buildings, ICSSC RP 5/NISTR 5734, National Institute of Standards and Technology, Gaithersburg, MD.

Interagency Committee on Seismic Safety. November 1995b. How-To Suggestions for Implementing Executive Order 12941 on Seismic Safety of Existing Federal Buildings, A Handbook, ICSSC TR-17/NISTR 5770, National Institute of Standards and Technology, Gaithersburg, MD.

Oak Ridge National Laboratory. Sent to Department of Energy-Oak Ridge Operations Office for Approval, October 1997. Safety Analysis Report for the Irradiated Materials Examination \& Testing Facility, Building 3025E, ORNL/M\&C/3025E/SAR/R0, Metals and Ceramics Division, Lockheed Martin Energy Research, Inc., Oak Ridge, TN.

Office of Nuclear Safety Policy and Standards. November 1996c. Management Plan for the Implementation of Executive Order 12941, Department of Energy, Washington, D.C.

Office of Nuclear Safety Policy and Standards. July 1998a. Implementation of Executive Order (E.O.) 12941 for Seismic Safety of Existing Buildings and Update on NPH Issues, Department of Energy, Washington, D.C.

Office of Nuclear Safety Policy and Standards. July 1998b. Implementation of Executive Order (E. O.) 12941 for Seismic Safety of Existing Buildings, Department of Energy, Washington, D.C. 
APPENDIX A

ORNL LEASED BUILDINGS 
ORNL LEASED BUILDINGS

\begin{tabular}{|l|l|}
\hline UNIQUE IDENTIFIER & DESCRIPTION \\
\hline 101 MID & 101 Midway Lane \\
\hline 1060 COMM & 1060 Commerce Park Drive \\
\hline FEDC & Fusion Energy Design Center \\
\hline GERMANTOWN, MD & Trevion II \\
\hline 78 MITCHELL & $72-78$ Mitchell Road \\
\hline CAPITAL GALLERY & Capital Gallery Office Complex \\
\hline
\end{tabular}


APPENDIX B

INITIAL BUILDING LIST - ORNL 
INITIAL BUILDING LIST - ORNL

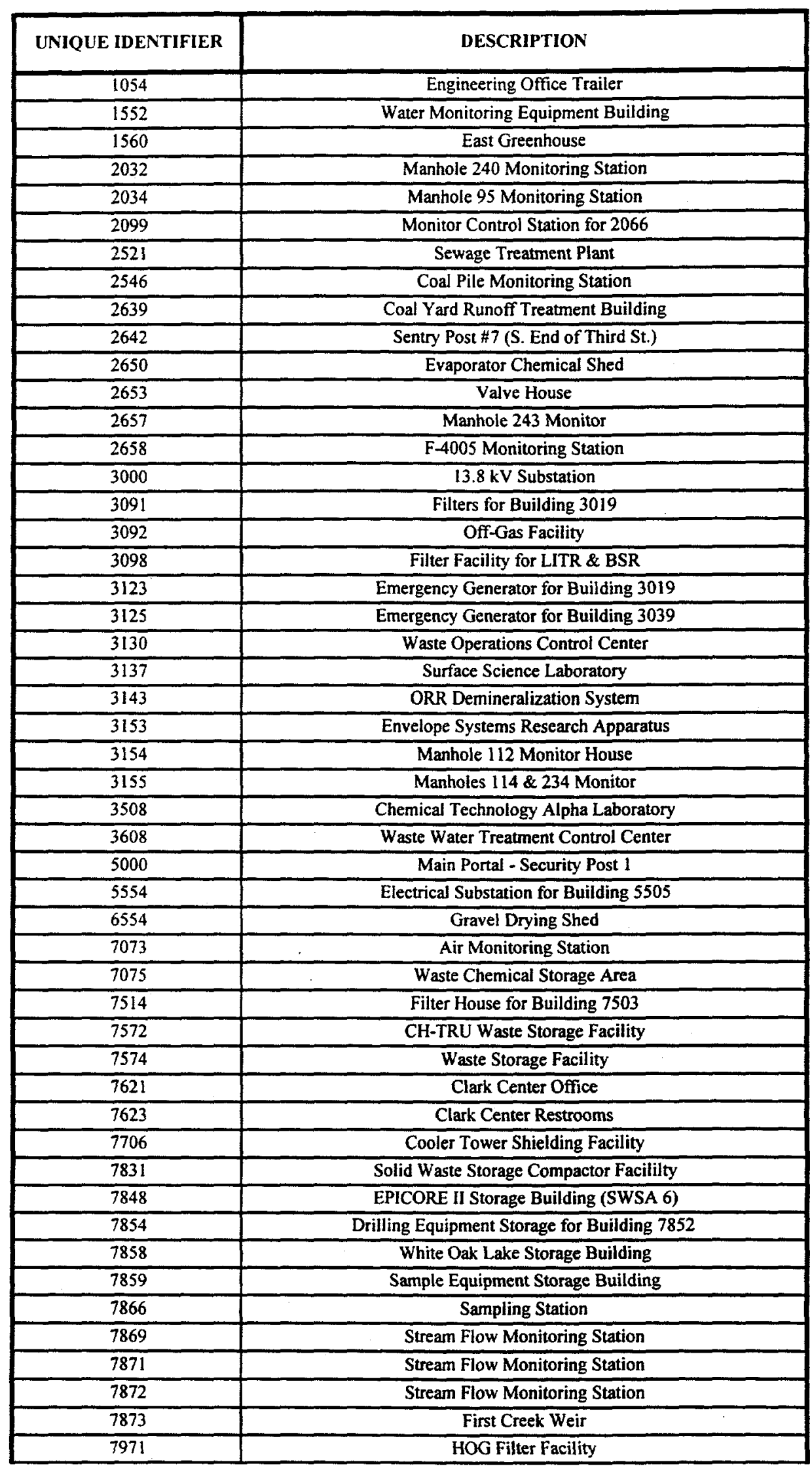


INITIAL BUILDING LIST - ORNL

\begin{tabular}{|c|c|}
\hline UNIQUE IDENTIFIER & DESCRIPTION \\
\hline 7975 & Water Monitoring Storage Facility \\
\hline 0813 & Field Laboratory \#1 \\
\hline 0814 & Field Laboratory \#2 \\
\hline 0817 & Ozone Generator Building \\
\hline 0818 & Atmospheric Instrument Trailer \\
\hline 0819 & Farm Implement Storage Buildin \\
\hline 0822 & ESD/NOAA USAF Instru TrI \\
\hline 0855 & Operations Building 0800 Area \\
\hline 0857 & Goat Building \\
\hline 0858 & Sycamore Plantation Trailer \\
\hline 0901 & 161 kV Substation \\
\hline 0903 & Bethel Valley Church \\
\hline 0907 & Walker Branch Watershed Lab \\
\hline 0934 & Walk Br Weir Sub-Sur Weir Ints \\
\hline 0937 & ATDD/NOAA Rain Gage 2 Instr \\
\hline 0940 & ATDD/NOAA Instrument Bldg 1 \\
\hline 0941 & ATDD/NOAA Instrument BIdg 2 \\
\hline 0942 & ATDDNNOAA USAF Trailer \\
\hline 0943 & ATDD, NOAA Facility \\
\hline 0950 & Walker Branch East Weir Instr. House \\
\hline 0951 & Walker Branch West Weir Instr. House \\
\hline 0955 & Walker Brance Storage Building \\
\hline 0957 & Sample Storage Building \\
\hline 0961 & Oml Visitor Overlook \\
\hline 0963 & White Oak Creek Headquarters Monitor Station \\
\hline 0964 & Waste Inspection Building \\
\hline 1000 & Engineering \\
\hline $1053 \mathrm{~A}$ & Construction Eng Office \\
\hline $1053 \mathrm{~B}$ & Construction Engineering Offic \\
\hline 1059 & Health Effects Information \\
\hline 1061 & Health Protection Services Fac \\
\hline 1062 & West Office Building \\
\hline 1503 & Plant Sciences Lab \\
\hline 1504 & Aquatic Ecology Lab \\
\hline 1505 & Environmental Science lab \\
\hline 1506 & Controlled Envimonment \& Animal Building \\
\hline 1507 & Life Sciences Data Analysis Bl \\
\hline 1508 & Aquatic Storage Building \\
\hline 1509 & Environmental Engineering Faci \\
\hline 1542 & Cylinder Storage Shed \\
\hline 1561 & West Greenhouse \\
\hline 1564 & 1564 Trailer \\
\hline 1565 & 1565 Trailer \\
\hline 2000 & Solid State Lab Annex \& Quality Assurance \& Inspection \\
\hline 2001 & Information Center Complex/Synthetic Fuel Storage \\
\hline 2003 & Process Water Cont Station \\
\hline 2007 & Health Physics Calibration Lab \\
\hline 2008 & HP Tech internal Dosimetry Lab/Whole Body Counter \\
\hline 2009 & Cafeteria Warehouse \\
\hline 2010 & Cafeteria \\
\hline
\end{tabular}

B - 2 


\section{INITIAL BUILDING LIST - ORNL}

\begin{tabular}{|c|c|}
\hline UNIQUE IDENTIFIER & DESCRIPTION \\
\hline 2011 & Mechanical Properties Lab \\
\hline 2013 & West Maintenance Service Center \\
\hline 2016 & West Portal Security HQ Annex \\
\hline 2017 & East Research Servic Satellite \\
\hline 2018 & Elect \& AC Service Center \\
\hline 2019 & Solar Energy Lab/Laser Lab \\
\hline 2024 & Quality Assurance \& Inspection//nformation Center \\
\hline 2026 & Hi-Rad Level Analytical Lab \\
\hline 2029 & Information Centr Com. Annex C \\
\hline 2030 & Mobile Office Unit \\
\hline 2033 & Measurement \& Controls Support Facility \\
\hline 2069 & Change House \\
\hline 2087 & Storage I-E \\
\hline 2088 & Emerg Generator B 2000 \\
\hline 2092 & Storage \\
\hline 2093 & Enviromental Storage Building \\
\hline 2101 & WMO Health\&Hyiegene Support \\
\hline 2500 & Protective Services Guard \& Fire Headquarters \\
\hline 2506 & Fabrication Shop \& Timekeeping \\
\hline 2510 & Air Compressor Buillding \\
\hline 2517 & Personnel Development \& Systems Department \\
\hline 2518 & P \& E Division Offices \\
\hline 2519 & Steam Plant \\
\hline 2523 & Decontamination Laudry \\
\hline $2523 \mathrm{~A}$ & Decontamination Laundry Annex \\
\hline 2525 & Fabrication Department Shop A \\
\hline 2528 & Coal Research Lab \\
\hline 2531 & Radioactive Waste Evaporator \\
\hline 2532 & Hi-Level Waste Stor Cooling Pu \\
\hline 2536 & Coal Sample Preparation Bldg. \\
\hline 2537 & Evaporator Service Tank \& Control Room for Building 2531 \\
\hline 2540 & Steam Plant Substation \\
\hline 2542 & Gas Storage Facility \\
\hline 2547 & Gen Machine Shop \\
\hline 2549 & Storage Bluilding Steam Plant \\
\hline 2568 & Cell Vent \& Off-Gas Filter - 2531 \\
\hline 2572 & Emergency Generator 2500 \\
\hline 2609 & Sentry Post No. 3 \\
\hline 2621 & ES\&H Offices \\
\hline 2628 & Fire Protect Maint \& Storage \\
\hline 2638 & Steam Plant Control Building \\
\hline 2640 & Sentry Post \#6 SW Vehicle Gate \\
\hline 2641 & Sentry Post \#6B (Coal Yard Del \\
\hline 2643 & Chlorinator Building \\
\hline 2644 & Coal Yard Runoff Treatment Pit \\
\hline 2647 & Construction Engineering Trail \\
\hline 2648 & Fire Training Facility \\
\hline 2649 & Transported Waste Receiving Facility \\
\hline $2652 \mathrm{~A}$ & $2652 \mathrm{~A}$ Office Trailer \\
\hline 2652B & 2652B Office Trailer \\
\hline
\end{tabular}


INITIAL BUILDING LIST - ORNL

\begin{tabular}{|c|c|}
\hline UNIQUE IDENTIFIER & DESCRIPTION \\
\hline $2652 \mathrm{C}$ & $2652 \mathrm{C}$ Office Trailer \\
\hline 2654 & Sewage Digester Building \\
\hline 2656 & Sewage Trt Plt-Wtr Monitor Sta \\
\hline 2660 & Operation Compliance Training \\
\hline 2661 & ORNL Regional Science Ed Ctr \\
\hline 3001 & Graphite Reactor \\
\hline 3002 & Filter House - Graphite Reactor \\
\hline 3003 & Surface Monitoring \& Characterization Lab \\
\hline 3004 & Water Demineralizer \\
\hline 3005 & Low-Intensity Testing Reactor \\
\hline 3008 & Source \& Spec Mat Vault \\
\hline 3009 & Pump House for Building 3010 \\
\hline 3010 & Bulk Shielding Reactor \\
\hline $3010 \mathrm{~A}$ & BSR Facility Building \\
\hline 3012 & Rolling Mill \\
\hline 3013 & Geo. Disp. Lab \\
\hline 3017 & Chem. Tech. Div. Annex \\
\hline $3019 A$ & Radiochemical Processing Pilot - Analytic \\
\hline 3019B & Radiochemical Processing Pilot Plant \\
\hline $3025 \mathrm{E}$ & M \& C Physical Examination - Hot Cells \\
\hline $3025 W$ & Solid State Division Offices \\
\hline $3026 \mathrm{C}$ & Radioisotope Development Laboratory \\
\hline $3026 \mathrm{D}$ & Dismantling and Exam - Hot Cells \\
\hline 3027 & Safeguard (SNM) Vault \\
\hline 3028 & Radioisotope Production Lab \\
\hline 3029 & Radioisotope Production Lab-B \\
\hline 3030 & Radioisotope Production Lab-C \\
\hline 3031 & Radioisotope Production Lab-D \\
\hline 3032 & Radioisotope Production Lab-E \\
\hline 3033 & Radioisotope Production Lab-F \\
\hline $3033 \mathrm{~A}$ & Radioisotope Prod Lab Annex \\
\hline 3034 & Radioisotope Area Services \\
\hline 3036 & Isotope Area Stor \& Servic Bld \\
\hline 3037 & Chem Tech Offices \\
\hline 3038 & Radioisotope Laboratory \\
\hline 3042 & Oak Ridge Research Reactor \\
\hline 3044 & Special Materials Machine Shop \\
\hline 3047 & Isotope Technology Building \\
\hline 3074 & Interim Manipulator Repair Facility \\
\hline 3080 & Reactor Exper Control Room \\
\hline 3082 & Stor Misc Material \\
\hline 3083 & Neutron Spectrometer Station 1 \\
\hline 3084 & Neutron Spectrometer Sta 2 \\
\hline 3085 & Pump House-Orr \\
\hline 3088 & Bulk Shield Reactor Storage \\
\hline 3095 & Reactor Area Equipment Building \\
\hline 3100 & Source \& Sp Mat Vault \\
\hline 3101 & Storage Shed \\
\hline 3104 & West Research Service Center \\
\hline 3105 & Waste Operations Health Physics Office \\
\hline
\end{tabular}

B - 4 


\section{INITIAL BUILDING LIST - ORNL}

\begin{tabular}{|c|c|}
\hline UNIQUE IDENTIFIER & DESCRIPTION \\
\hline 3107 & 25 Meter Target Hse. \\
\hline 3108 & Cell \& Hood Vent Filters \\
\hline 3111 & Sentry Post No $8 b$ \\
\hline 3112 & Misc. Storage Building \\
\hline 3114 & Roof Test Development Lab \\
\hline 3115 & Solid State Off. \\
\hline 3115 & Nitrogen Cylinder Storage Bldg \\
\hline 3118 & Radioisotope Prod Lab-H \\
\hline 3119 & Heat Exchanger and Pump House \\
\hline 3121 & Cell Off Gas Filter Hse for \\
\hline 3127 & Non-Nuclear Res. Matl'S Vault \\
\hline 3129 & Personnel Monitoring Station \\
\hline 3135 & Sentry Post - 8D \\
\hline 3136 & Mock Up Test Facility \\
\hline 3138 & Roof Thermal Test Fac \\
\hline 3141 & S Pass Shelter Bethel Valley $\mathbf{R}$ \\
\hline 3142 & S Passenger Shelter Bethel Val \\
\hline 3144 & Roof Test Center \\
\hline 3145 & LLW Collection Building \\
\hline 3147 & Office for Efficiency Renewable Research \\
\hline 3150 & Solid State Research Facility \\
\hline 3156 & Energy Office \& Support Fac \\
\hline 3158 & N Monitoring Bldg 3025/3026 \\
\hline 3159 & S Monitoring Bldg 3500/4500 \\
\hline 3500 & Instrument \& Controls (East) \\
\hline 3501 & Sewage Pumping Sta. \\
\hline 3502 & East Research Service Center \\
\hline $3502 \mathrm{~B}$ & Data Concen 4 WOCC DAS 3502 \\
\hline 3503 & High Radiation-Level Engineering Laboratory \\
\hline 3504 & Geoscience Laboratory \\
\hline 3505 & Metal Recovery Facility \\
\hline 3515 & Fission Prod Lab No 1 \\
\hline 3517 & Fission Products Dev Lab \\
\hline 3518 & Proc Waste Water Trtmt \\
\hline 3523 & I\&C Storage \\
\hline 3525 & High Rad Level Exam Lab. \\
\hline $3531 A$ & Trailer \\
\hline $3531 \mathrm{~B}$ & Trailer \\
\hline 3534 & Liquid Metal Cleaning Fac \\
\hline $3534 \mathrm{~A}$ & Health Physics Trailer \\
\hline $3534 \mathrm{~B}$ & Health Physics Trailer \\
\hline 3541 & MSR Process Dev. Lab. \\
\hline 3542 & Str Bldg For $3505 \& 3517$ \\
\hline 3543 & Msr Dev Lab \\
\hline 3544 & Proc Waste Treatment PIt \\
\hline $3544 A$ & ORNL WstWtr Treatment Fac \\
\hline 3544B & Filter Press Building \\
\hline 3546 & I \& C Office Annex \\
\hline 3550 & Research Materials Preparation \\
\hline 3587 & Instrument Laboratory Annex/Clothing Stores \\
\hline
\end{tabular}


INITIAL BUILDING LIST - ORNL

\begin{tabular}{|c|c|}
\hline UNIQUE IDENTIFIER & DESCRIPTION \\
\hline 3592 & Coal Conversion Facility \\
\hline 3594 & Waste Mgmt Stor Bldg \\
\hline 3598 & Emerg Gen For 3500 Area \\
\hline 3602 & Cylinder Tank Stor Bldg 3525 \\
\hline 3605 & TSD Storage Building \\
\hline 3606 & South Office Annex \\
\hline 3607 & Cask Tool Stor \\
\hline 3610 & Storage Building \\
\hline $3610 \mathrm{~A}$ & Flammable Storage Building \\
\hline 3618 & WC-10 Building \\
\hline 4005 & Sentry Post Portal \\
\hline 4007 & Waste Operations Support Facil \\
\hline $4500 \mathrm{~N}$ & Central Research \& Administration \\
\hline $4500 S$ & Central Research \& Administration \\
\hline 4501 & Pumping Station \\
\hline 4505 & Experimental Engineering \\
\hline 4507 & High Radiation Level Chemical Development Laboratory \\
\hline 4508 & Metals \& Ceramics Laboratory \\
\hline 4509 & Compressor House \\
\hline 4512 & Lab Emergency Response Center \\
\hline 4514 & Equipment Building - Html \\
\hline 4515 & High Temperature Material Laboratory \\
\hline 4557 & Sentry Post \#7-South Parking \\
\hline 4558 & 4558 Office Trailer \\
\hline 5002 & Guest Users Facility \\
\hline 5500 & High Voltage Accelerator Laboratory \\
\hline $5500 \mathrm{~A}$ & M \& C South Office Annex \\
\hline 5505 & Transuranium Research Laboratory \\
\hline 5506 & East Portal Building - Security Post 11 \\
\hline 5507 & Electron Spectrometer Fac \\
\hline 5510 & Analytical Mass Spectrometer Lab \\
\hline $5510 \mathrm{~A}$ & Inorganic Mass Spectrometer Lab \\
\hline 5553 & Sentry Post le \\
\hline 6000 & Holifield Heavy Ion Research Facility \\
\hline $6000 \mathrm{~B}$ & Atomic Physics Research Laboratory \\
\hline 6003 & Modular Building for Offices \\
\hline 6005 & Gas Compressor Hse 6000 \\
\hline 6007 & Joint Institute for Heavy Ion Research \\
\hline 6008 & JIHIR Office/Lab Facility \\
\hline 6010 & Electron Linear Accelerator \\
\hline 6011 & Computing \& Telecommunications Building \\
\hline 6012 & Computer Science Research Fac. \\
\hline 6016 & Outfall 314 Dechlorination System \\
\hline 6025 & Engineering Physics Office/Lab Building \\
\hline $6026 \mathrm{~A}$ & $6026 \mathrm{~A}$ Office Trailer \\
\hline $6026 B$ & 6026B Office Trailer \\
\hline $6026 \mathrm{C}$ & $6026 \mathrm{C}$ Office Trailer \\
\hline $6026 \mathrm{D}$ & $6026 \mathrm{D}$ Office Trailer \\
\hline $6026 \mathrm{E}$ & 6026E Office Trailer \\
\hline $6026 \mathrm{~F}$ & 6026F Trailer \\
\hline
\end{tabular}


INITIAL BUILDING LIST - ORNL

\begin{tabular}{|c|c|}
\hline UNIQUE IDENTIFIER & DESCRIPTION \\
\hline $6026 \mathrm{G}$ & Office Trailer, Double Wide \\
\hline $6556 \mathrm{~A}$ & ER Fieid Operations \\
\hline $6556 \mathrm{~B}$ & ER Field Operations \\
\hline $6556 \mathrm{C}$ & ER Field Operations \\
\hline $6556 \mathrm{D}$ & ER Field Operations \\
\hline $6556 \mathrm{E}$ & ER Field Operations \\
\hline 65560 & ER Field Operations \\
\hline $6556 \mathrm{~J}$ & Trailer, Single Wide \\
\hline $6556 \mathrm{~K}$ & Trailer, Single Wide \\
\hline $6556 \mathrm{~L}$ & Trailer, Single Wide \\
\hline $6556 \mathrm{M}$ & ER Field Operations \\
\hline $6556 Q$ & ER Field Operations \\
\hline $6556 \mathrm{R}$ & ER Field Operations \\
\hline $6556 \mathrm{~S}$ & ER Field Operations \\
\hline $6556-S T-9$ & Storage Trailer \\
\hline $6556 \mathrm{~T}$ & ER Field Operations \\
\hline 7001 & General Stores \\
\hline 7002 & Garage \& Iron Working Shop \\
\hline 7003 & Welding \& Brazing Shop \\
\hline 7005 & Lead Shop \\
\hline 7006 & Paint Stores \\
\hline 7007 & Paint Shop \\
\hline 7009 & Carpenter Shop \\
\hline 7010 & Dry Lumber Storage \\
\hline 7012 & Central Mechanical Shop \\
\hline 7013 & Acid Chem \& Flam Liq Stg \\
\hline 7015 & Metal Storage \& Cutting Facility \\
\hline 7018 & Salvage \& Reclamation Facility \\
\hline 7019 & Haz Materials Storage \\
\hline 7020 & Interim Gmds Equip Stg \\
\hline $7020 \mathrm{~A}$ & Decommission and Segregation Facility \\
\hline 7021 & Fab Equip Storage \\
\hline 7025 & Tritium Target Prep Facility \\
\hline 7026 & M\&C Storage \\
\hline 7031 & Fabrication Storage Shed \\
\hline 7033 & Electrical Material Strg. \\
\hline 7035 & Bldg Maint/Mat \& Equip \\
\hline $7035 \mathrm{~A}$ & Storage \\
\hline $7035 B$ & Storage \\
\hline $7035 \mathrm{C}$ & Storage \\
\hline $7035 \mathrm{D}$ & Storage \\
\hline 7037 & Cold Storage BIdg \\
\hline 7038 & Synthetic Fuel Storage Facilit \\
\hline 7039 & Material Staging Facility \\
\hline 7040 & Gas Cylinder Storage \\
\hline 7041 & Cold Storage Bldg \\
\hline 7042 & Core Storage Facility \\
\hline 7043 & Passenger Sheiter (W of 7000$)$ \\
\hline 7053 & Personnel Shelter \\
\hline 7055 & Storage Bldg. (Pickling Vats) \\
\hline
\end{tabular}


INITIAL BUILDING LIST - ORNL

\begin{tabular}{|c|c|}
\hline UNIQUE IDENTIFIER & DESCRIPTION \\
\hline 7057 & Sandblast Cleaning Fac \\
\hline 7058 & Machine Auxiliaries Strg \\
\hline 7060 & Steel Yard Office \\
\hline 7061 & Hlth.Phys. Envm. Stg. \\
\hline 7062 & Storage-Miscel Materials \\
\hline 7063 & Emerg Gen For Bldg 7003 \\
\hline 7065 & Rigger Equip Storage \\
\hline 7066 & Grounds Maint.Storage \\
\hline 7067 & Training Facility \\
\hline $7067 \mathrm{~A}$ & Office Trailer \\
\hline 7069 & Gas Service Facility \\
\hline 7070 & Storage Shed \\
\hline 7072 & Sentry Post $20 b$ \\
\hline 7074 & Sentry Post $\# 20$ C-PedGte 7012 \\
\hline 7077 & Grounds \& Laborers Building \\
\hline 7077.4 & Reservation Services Office Trailer \\
\hline $7078 \mathrm{~A}$ & 7078A EROffice Trailer \\
\hline $7078 \mathrm{~B}$ & Bechtel Jacobs Office Trailer \\
\hline $7078 \mathrm{C}$ & 7078C ER Office Trailer \\
\hline $7078 \mathrm{D}$ & Trailer \\
\hline $7078 \mathrm{E}$ & Trailer \\
\hline $7078 \mathrm{~F}$ & Trailer \\
\hline 7079 & Bottle Storage Building \\
\hline 7082 & Salt Storage Building \\
\hline 7083 & ESD Model Airplane Shop \\
\hline 7500 & Nuclear Safety Pilot Plant \\
\hline 7503 & CPAF Headquarters \\
\hline 7505 & Cpaf Headquarters \\
\hline 7506 & CPAF Carpenter Shop \\
\hline 7507 & Substores \\
\hline $7507 W$ & Mixed Hazardous Waste Stor Pad \\
\hline 7509 & MSRE Office Building \\
\hline 7516 & Field Service Shop \\
\hline 7518 & Concrete Storage Pad \\
\hline 7553 & Pump House - Tsf Water \\
\hline $7554 \mathrm{~A}$ & MK-Ferguson Trailer \\
\hline 7555 & Diesel Gnerator House for Building 7503 \\
\hline 7567 & Intermediate Level Waste Pumping Station \\
\hline 7569 & Collection Tank Melton \\
\hline 7582 & Liquid/Gaseous Waste Support \\
\hline 7600 & Containment Building \\
\hline 7601 & Office Building \\
\hline 7602 & Engineering Integrated Process Demo \\
\hline 7603 & Experimental Engineering - Remote Operations \& Maintenance \\
\hline 7604 & Utility Building \\
\hline 7605 & Storage Building \\
\hline $7606 \mathrm{~A}$ & Robotics R\&D Lab \\
\hline $7606 \mathrm{~B}$ & Maintenance Building \\
\hline 7607 & Egcr River Pump Station \\
\hline 7608 & Component Dev-R\&Ps \\
\hline
\end{tabular}


INITIAL BUILDING LIST - ORNL

\begin{tabular}{|c|c|}
\hline UNIQUE IDENTIFIER & DESCRIPTION \\
\hline 7609 & Stack Monitoring House \\
\hline 7610 & Storage House - R\&Ps \\
\hline 7611 & Guard House - CFRP Security Post 30 \\
\hline 7615 & REDC Storage \\
\hline 7651 & Storage Shed \\
\hline 7652 & Hazardous Waste Storage Building \\
\hline 7653 & Chemical Waste Storage Building \\
\hline 7654 & Hazardous Waste Storage Building \\
\hline 7661 & Electrical Utility Building \\
\hline 7666 & Environmental Emer. Resp_Fac \\
\hline $7666 \mathrm{~A}$ & Trailer, Dbl Wide-7666A Area \\
\hline 7668 & Mixed Waste Storage Facility \\
\hline 7702 & Control House Tower Shielding Facility \\
\hline 7703 & Hoist House-Tsf \\
\hline 7704 & Control House-Tsf \\
\hline 7705 & Pump House-Tsf \\
\hline 7707 & Battery House-Tsf \\
\hline 7708 & Reactor Shield Storage-Tsf \\
\hline 7709 & Health Physics Res. Reac. \\
\hline 7710 & DOSAR Facility - HPRR \\
\hline 7712 & Dosar Low-Eng Accelerator \\
\hline 7716 & Filter Pump House Main. Pool \\
\hline 7720 & Civil Defense Bunker \\
\hline 7735 & Radiation Calibration Laboratory \\
\hline 7740 & Radio Trans. Fac. (Melton \\
\hline 7751 & Sen Post 22 Tsf Exclu \\
\hline 7752 & Sen Post 21 Tsf Perimeter \\
\hline 7756 & Meter House Hpm \\
\hline 7758 & HFIR Parts Storage \\
\hline $7802 \mathrm{C}$ & Deep Monitoring Well \#1 \\
\hline $7802 \mathrm{D}$ & Deep Monitoring Well $\# 2$ \\
\hline $7802 \mathrm{~F}$ & Garage at SWSA5 \\
\hline 7803 & Lab Trailer \\
\hline 7811 & Geosciences Storage Building \\
\hline 7819 & Interim Decontamination \\
\hline 7823 & Underground Storage Bldg \\
\hline 7824 & Waste Exam \& Assay Facility \\
\hline $7824 \mathrm{~A}$ & WEAF Support Facility \\
\hline 7826 & TRU Drum Storage \\
\hline 7830 & LLW Storage Tank Facility \\
\hline $7831 \mathrm{~A}$ & Solid Waste Compactor \\
\hline 7833 & Alpha Greenhouse Facility. \\
\hline 7834 & Retrievable Waste Storage Facility \\
\hline $7841 \mathrm{~A}$ & Decon Trailer-SWSA 5 Area \\
\hline 7842 & Storage Shelter Swsa \#6 \\
\hline 7847 & Vehicle/Personnel Monitor Sta \\
\hline 7849 & White Oak Crk Weir \& Gaging St \\
\hline 7852 & Shale Fracturing Batch Plant \\
\hline 7853 & Gen Storage Bldg 7852 \\
\hline 7855 & Concrete Cask Storage Facility for HRL Retrievable Waste \\
\hline
\end{tabular}


INITIAL BUILDING LIST - ORNL

\begin{tabular}{|c|c|}
\hline UNIQUE IDENTIFIER & DESCRIPTION \\
\hline 7856 & MVST Capacity Increase Project \\
\hline 7857 & IWMF Monitoring Station \\
\hline $7859 \mathrm{~A}$ & Sample Storage Building \\
\hline $7859 \mathrm{~B}$ & Sample Storage Building \\
\hline 7860 & New Hydrofracturing Facility \\
\hline 7863 & Gen Strg For Bldg 7860 \\
\hline 7874 & ESD Stor Bldg (SW SWSA 4) \\
\hline 7875 & Monitoring Storage Bldg. \\
\hline 7876 & Office Trailer \\
\hline 7877 & LLW Solidifaction Facility \\
\hline 7878 & SWSA 6 Staging Facility \\
\hline 7879 & TRU/LLW Staging Facility \\
\hline 7881 & Guard Post 24 (W End of Plant) \\
\hline 7883 & RH-TRU Waste Storage Bunker \\
\hline 7900 & High Flux Isotope Reactor \\
\hline 7901 & Elec Bldg For 7900 \\
\hline 7903 & Cooling Twr Equip Bldg \\
\hline 7910 & Office Building for Building 7900 \\
\hline 7912 & Fan Shed for 7911 \\
\hline 7914 & Eqp \& Parts Strge Bldg \\
\hline $7914 \mathrm{~A}$ & Equipment Storage \\
\hline 7915 & Oper. Stor. Bldg. \\
\hline 7916 & HFIR Cooling Tower Softener \\
\hline 7917 & Research Reactors Division Office Building \\
\hline 7918 & REDC Office \& Training Facilit \\
\hline 7919 & Process Waste Monitor (HFIR) \\
\hline 7920 & Transuranium Processing Facility \\
\hline 7921 & Emerg Gen Bldg (For B7920 \\
\hline 7922 & Breeching \& Fan Area for 7920 \\
\hline $7924 \mathrm{~A}$ & Storage Building for 7920 \\
\hline 7924-B & Storage Building \\
\hline 7930 & Radiochemical Engineering Development Center \\
\hline 7931 & Emergency Generator for Building 7930 \\
\hline 7932 & Waste Sampling Building for Building 7930 \\
\hline 7933 & 7933 Storage Trailer \\
\hline 7934 & Photographic Waste Storage Facility \\
\hline 7935 & Waste Storage Fac \\
\hline 7936 & Storage Facility for REDC \\
\hline 7952 & Low Lev Waste Pmp Sta \\
\hline 7953 & Hpr Pump House \\
\hline $7953 \mathrm{~A}$ & Trailer \\
\hline $7953 B$ & Trailer \\
\hline $7953 \mathrm{C}$ & Trailer \\
\hline 7955 & Sentry Post No. 19A \\
\hline 7957 & Office Trailer For 7920 \\
\hline 7958 & Sentry Post 23 - Hprr \\
\hline 7960 & Cask Tool Stor \\
\hline 7962 & Neutron Users Office \& Laboratory \\
\hline $7964 \mathrm{~A}$ & Triple Wide Office Trailer \\
\hline $7964 \mathrm{~B}$ & Triple Wide Office Trailer \\
\hline
\end{tabular}


INITIAL BUILDING LIST - ORNL

\begin{tabular}{|c|c|}
\hline UNIQUE IDENTIFIER & DESCRIPTION \\
\hline $7964 \mathrm{C}$ & Trailer, Office \\
\hline $7964 \mathrm{D}$ & 7964D Office Trailer \\
\hline $7964 \mathrm{E}$ & 7964E Conference Trailer \\
\hline $7964 \mathrm{~F}$ & 7964F Office Trailer \\
\hline $7964 G$ & Office Trailer, Triplewide \\
\hline $7965 \mathrm{~A}$ & Trailer, Office \\
\hline $7965 \mathrm{~B}$ & 7965B Office Trailer \\
\hline $7965 \mathrm{C}$ & 7965C Office Trailer \\
\hline 7966 & LLW Monitoring\&Collection Sta \\
\hline 7967B & Subsurface Wier Instr Bldg \\
\hline 7968 & Trailer \\
\hline 7969 & Haz Material Enclosure \\
\hline 910003 & Shed D Butler \\
\hline 910004 & Barn D \\
\hline 910006 & Bam E \\
\hline$\overline{910007}$ & Barn Twin I \\
\hline 910009 & Bam B \\
\hline 910010 & Barn Solway \\
\hline 910022 & Guard House Filter Plant \\
\hline 910023 & Barn Freels \\
\hline 910024 & White Barn \\
\hline 910025 & Silo $14 \times 41$ \\
\hline 910027 & Sheep Bam \\
\hline $\mathrm{X} 176230$ & 3515 Area Trailer \\
\hline $\mathrm{X} 185248$ & X185248 Trailer-SWSA \#6 \\
\hline $\mathrm{X} 185249$ & X185249 Trailer-SWSA \#6 \\
\hline $\mathrm{X} 186600$ & Trailer-7002 Area \\
\hline $\mathrm{X} 186689$ & Trailer Mobile House Unit-2531 \\
\hline
\end{tabular}


APPENDIX C

ORNL EXEMPT BUILDINGS 
ORNL EXEMPT BUILDINGS, SORTED BY EXEMPTION CRITERIA

\begin{tabular}{|c|c|c|c|c|c|c|c|}
\hline AGENCY CODE & UNIQUE IDENTIFIER & STATE CODE & COUNTY CODE & SEISMICITY & AREA, $\mathbf{m}^{2}$ & $\begin{array}{l}\text { NUMBER OF } \\
\text { BUILDINGS }\end{array}$ & EXEMPTION CRITERIA \\
\hline 8900 & 2032 & 47 & 001 & $\mathbf{M}$ & 6 & 1 & E1 \\
\hline 8900 & 2034 & 47 & 001 & $\mathbf{M}$ & 6 & 1 & E1 \\
\hline 8900 & 2521 & 47 & 001 & $M$ & 137 & 1 & E1 \\
\hline 8900 & 2546 & 47 & 001 & $M$ & 5 & 1 & E1 \\
\hline 8900 & 2650 & 47 & 001 & $M$ & 9 & 1 & EI \\
\hline 8900 & 2657 & 47 & 001 & $\mathbf{M}$ & 9 & 1 & El \\
\hline 8900 & 2658 & 47 & 001 & $\mathbf{M}$ & 9 & 1 & E1 \\
\hline 8900 & 3000 & 47 & 001 & $\mathbf{M}$ & 137 & 1 & E1 \\
\hline 8900 & 3091 & 47 & 001 & $\mathrm{M}$ & 56 & 1 & El \\
\hline 8900 & 3092 & 47 & 001 & $M$ & 167 & 1 & E1 \\
\hline 8900 & 3098 & 47 & 001 & $\bar{M}$ & 114 & 1 & $\mathrm{EI}$ \\
\hline 8900 & 3123 & 47 & 001 & $\mathbf{M}$ & 24 & 1 & E1 \\
\hline 8900 & 3125 & 47 & 001 & $\bar{M}$ & 44 & 1 & E1 \\
\hline 8900 & 3143 & 47 & 001 & $\mathbf{M}$ & 24 & 1 & $\mathrm{E} 1$ \\
\hline 8900 & 3153 & 47 & 001 & $M$ & 214 & 1 & El \\
\hline 8900 & 5554 & 47 & $00 !$ & $M$ & 31 & 1 & EI \\
\hline 8900 & 7073 & 47 & 001 & $\mathbf{M}$ & 6 & 1 & El \\
\hline 8900 & 7623 & 47 & 001 & $M$ & 89 & 1 & E1 \\
\hline 8900 & 7706 & 47 & 001 & $\mathbf{M}$ & 74 & 1 & EI \\
\hline 8900 & 7858 & 47 & 001 & $\mathbf{M}$ & 23 & 1 & EI \\
\hline 8900 & 7869 & 47 & 001 & $\mathbf{M}$ & 14 & 1 & EI \\
\hline 8900 & 7871 & 47 & 001 & $M$ & 24 & 1 & E1 \\
\hline 8900 & 7872 & 47 & 001 & $\bar{M}$ & 24 & 1 & EI \\
\hline 8900 & 7873 & 47 & 001 & $\mathbf{M}$ & 18 & 1 & EI \\
\hline 8900 & 7971 & 47 & 001 & $\mathbf{M}$ & 80 & 1 & E1 \\
\hline 8900 & 7975 & 47 & 001 & $\mathbf{M}$ & 2 & 1 & EI \\
\hline 8900 & 0857 & 47 & 001 & $\mathbf{M}$ & 33 & 1 & E1 \\
\hline 8900 & 0858 & 47 & 001 & $\bar{M}$ & 27 & 1 & E1 \\
\hline 8900 & 0901 & 47 & 001 & $\mathbf{M}$ & 80 & 1 & E1 \\
\hline 8900 & 0903 & 47 & 001 & $\mathbf{M}$ & 147 & 1 & E1 \\
\hline 8900 & 0937 & 47 & 001 & $\mathbf{M}$ & 16 & 1 & E1 \\
\hline 8900 & 0943 & 47 & 001 & $\mathrm{M}$ & 61 & 1 & El \\
\hline 8900 & 0950 & 47 & 001 & $M$ & 9 & 1 & E1 \\
\hline 8900 & 0951 & 47 & 001 & $M$ & 9 & 1 & $\overline{E 1}$ \\
\hline 8900 & 0961 & 47 & 001 & $M$ & 465 & 1 & $\mathrm{El}$ \\
\hline 8900 & 0963 & 47 & 001 & $M$ & 9 & 1 & EI \\
\hline
\end{tabular}

\section{C -1}




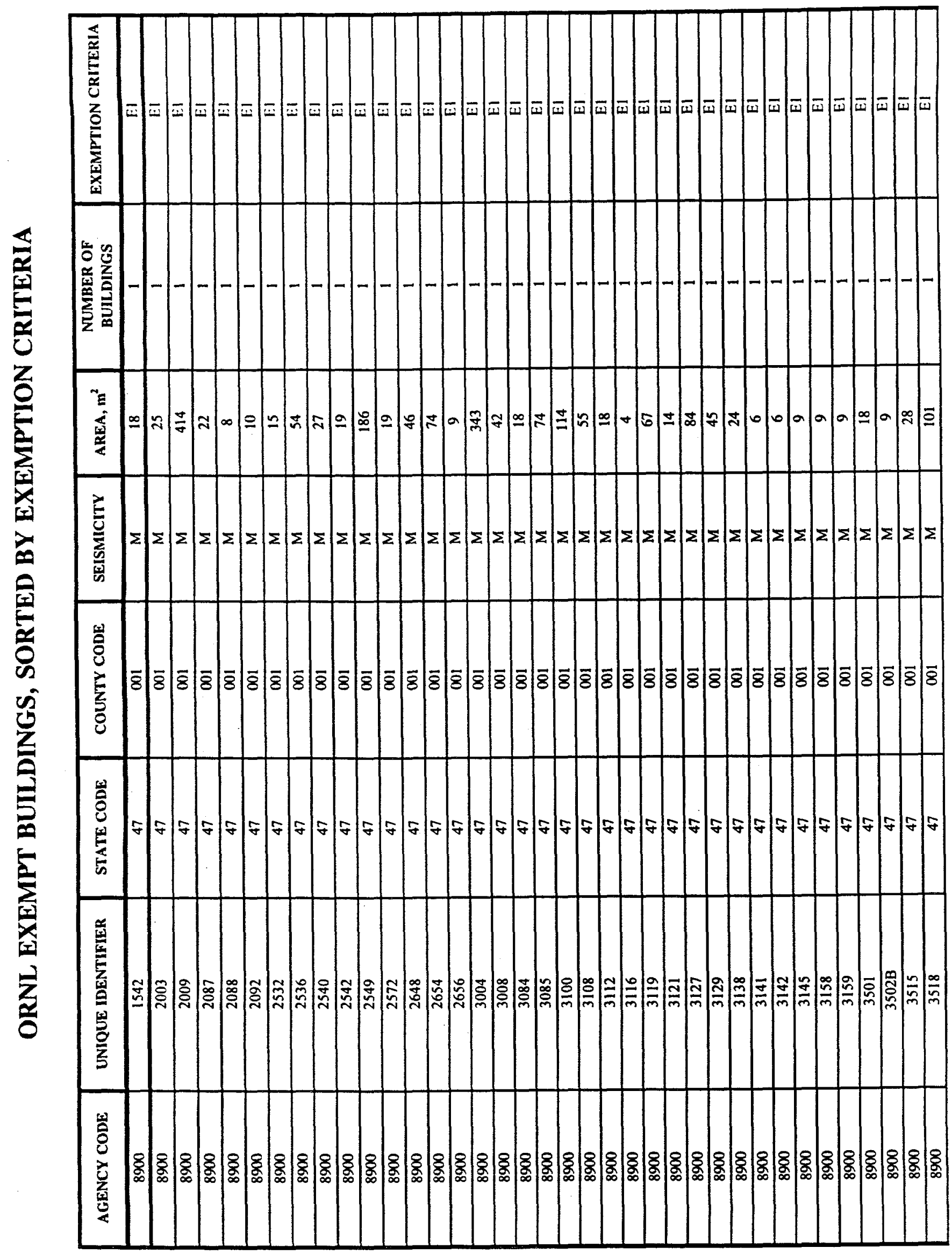




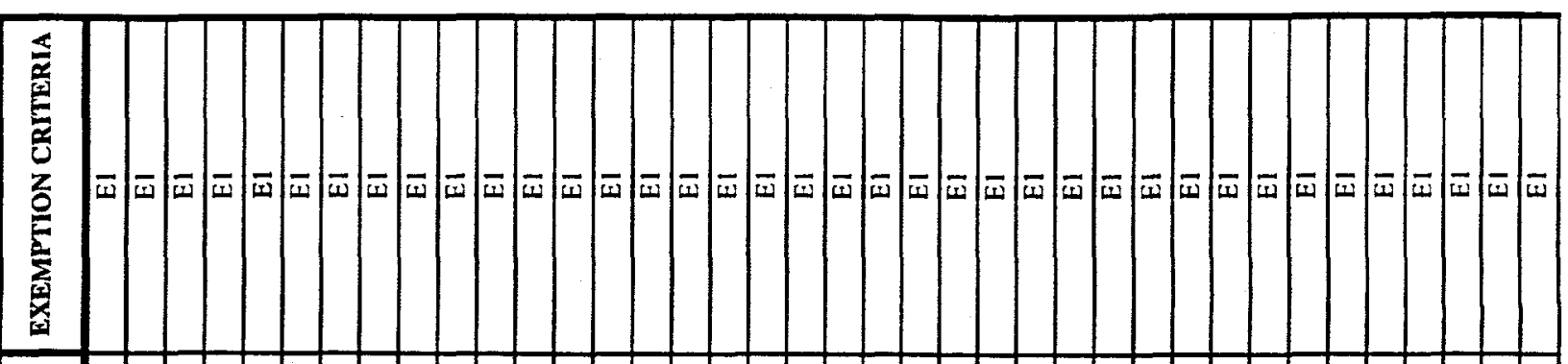

要是

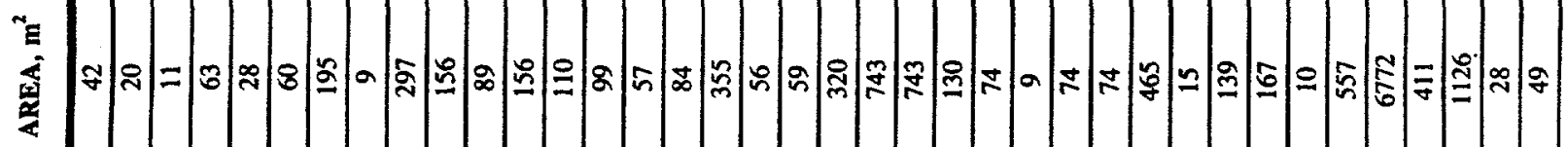

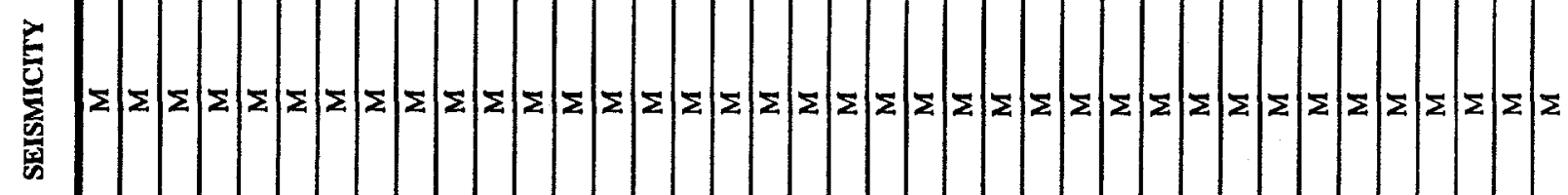

茲

遂

点

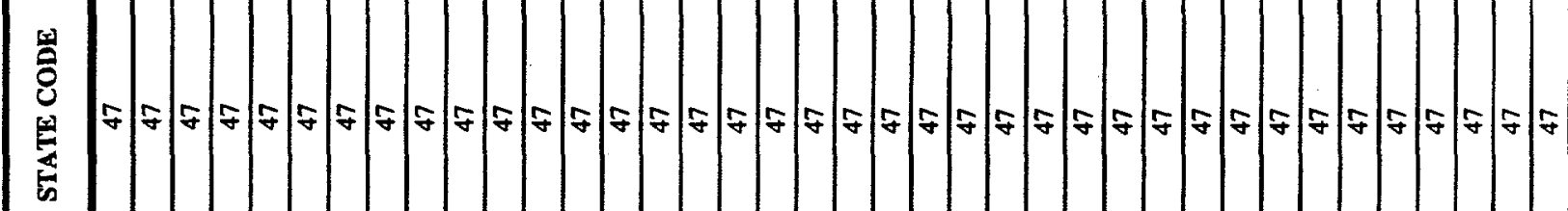

产

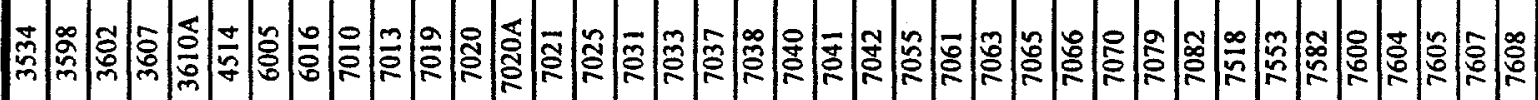

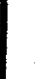

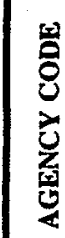

央央 
ORNL EXEMPT BUILDINGS, SORTED BY EXEMPTION CRITERIA

\begin{tabular}{|c|c|c|c|c|c|c|c|}
\hline AGENCY CODE & UNIQUE IDENTIFIER & STATE CODE & COUNTY CODE & SEISMICITY & AREA, $\mathbf{m}^{2}$ & $\begin{array}{l}\text { NUMBER OF } \\
\text { BUILDINGS }\end{array}$ & EXEMPTION CRITERIA \\
\hline 8900 & 7609 & 47 & 001 & $\mathbf{M}$ & 72 & 1 & EI \\
\hline 8900 & 7610 & 47 & 001 & $M$ & 35 & 1 & EI \\
\hline 8900 & 7615 & 47 & 001 & $\mathbf{M}$ & 71 & 1 & E1 \\
\hline 8900 & 7651 & 47 & 001 & $\bar{M}$ & 74 & 1 & EI \\
\hline 8900 & 7661 & 47 & 001 & $\bar{M}$ & 13 & 1 & E1 \\
\hline 8900 & 7666 & 47 & 001 & $\mathbf{M}$ & 260 & 1 & El \\
\hline 8900 & 7703 & 47 & 001 & $\mathbf{M}$ & 139 & 1 & EI \\
\hline 8900 & 7704 & 47 & 001 & $\mathbf{M}$ & 208 & 1 & E1 \\
\hline 8900 & 7705 & 47 & 001 & $\mathbf{M}$ & 50 & 1 & EI \\
\hline 8900 & 7707 & 47 & 001 & $\mathbf{M}$ & 40 & 1 & El \\
\hline 8900 & 7708 & 47 & 001 & $\mathbf{M}$ & 304 & 1 & E1 \\
\hline 8900 & 7709 & 47 & 001 & $\mathbf{M}$ & 279 & 1 & E1 \\
\hline 8900 & .7716 & 47 & 001 & $M$ & 51 & 1 & $\mathrm{El}$ \\
\hline 8900 & 7720 & 47 & 001 & $\mathbf{M}$ & 223 & 1 & $\mathrm{El}$ \\
\hline 8900 & 7740 & 47 & 001 & $\mathbf{M}$ & 9 & 1 & $\mathrm{El}$ \\
\hline 8900 & 7756 & 47 & 001 & $\bar{M}$ & 17 & 1 & E1 \\
\hline 8900 & 7758 & 47 & 001 & $\mathbf{M}$ & 37 & 1 & EI \\
\hline 8900 & 7811 & 47 & 001 & $\mathbf{M}$ & 50 & 1 & EI \\
\hline 8900 & 7833 & 47 & 001 & $\mathbf{M}$ & 48 & 1 & E1 \\
\hline 8900 & 7849 & 47 & 001 & $\mathbf{M}$ & 9 & 1 & E1 \\
\hline 8900 & 7853 & 47 & 001 & $\mathbf{M}$ & 56 & 1 & E1 \\
\hline 8900 & $7859 A$ & 47 & 001 & $\mathrm{M}$ & 5 & 1 & E1 \\
\hline 8900 & 7874 & 47 & 001 & $M$ & 223 & 1 & E1 \\
\hline 8900 & 7901 & 47 & 001 & $\mathbf{M}$ & 292 & 1 & El \\
\hline 8900 & 7903 & 47 & 001 & $\mathbf{M}$ & 59 & 1 & E1 \\
\hline 8900 & 7916 & 47 & 001 & $\mathbf{M}$ & 58 & 1 & E1 \\
\hline 8900 & 7921 & 47 & 001 & $\mathbf{M}$ & 19 & 1 & E1 \\
\hline 8900 & $7924 \mathrm{~A}$ & 47 & 001 & $\bar{M}$ & 26 & 1 & E1 \\
\hline 8900 & 7952 & 47 & 001 & $\mathbf{M}$ & 24 & 1 & E1 \\
\hline 8900 & 7953 & 47 & 001 & $M$ & 25 & 1 & E1 \\
\hline 8900 & 7967B & 47 & 001 & $\mathbf{M}$ & 9 & 1 & E1 \\
\hline 8900 & 7969 & 47 & 001 & $\mathbf{M}$ & 22 & 1 & E1 \\
\hline 8900 & 910003 & 47 & 001 & $\mathbf{M}$ & 186 & 1 & E1 \\
\hline 8900 & 910004 & 47 & 001 & $\mathbf{M}$ & 746 & 1 & $\mathrm{E} 1$ \\
\hline 8900 & 910006 & 47 & 001 & $\mathbf{M}$ & 746 & 1 & El \\
\hline 8900 & 910007 & 47 & 001 & $\mathbf{M}$ & 386 & 1 & $E 1$ \\
\hline 8900 & 910009 & 47 & 001 & $\mathbf{M}$ & 476 & 1 & E1 \\
\hline 8900 & 910010 & 47 & 001 & $\mathbf{M}$ & 476 & 1 & EI \\
\hline
\end{tabular}

C -4 


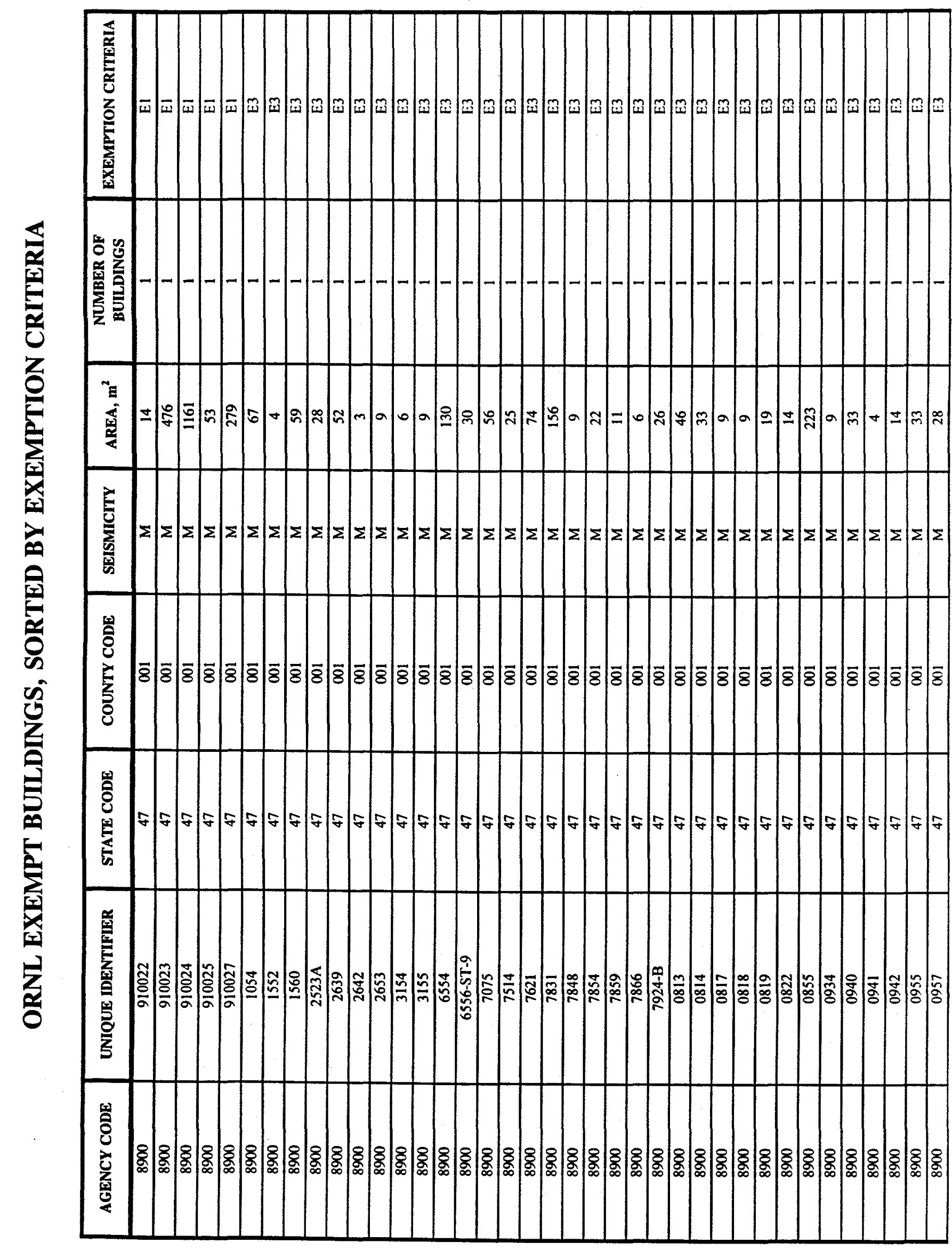




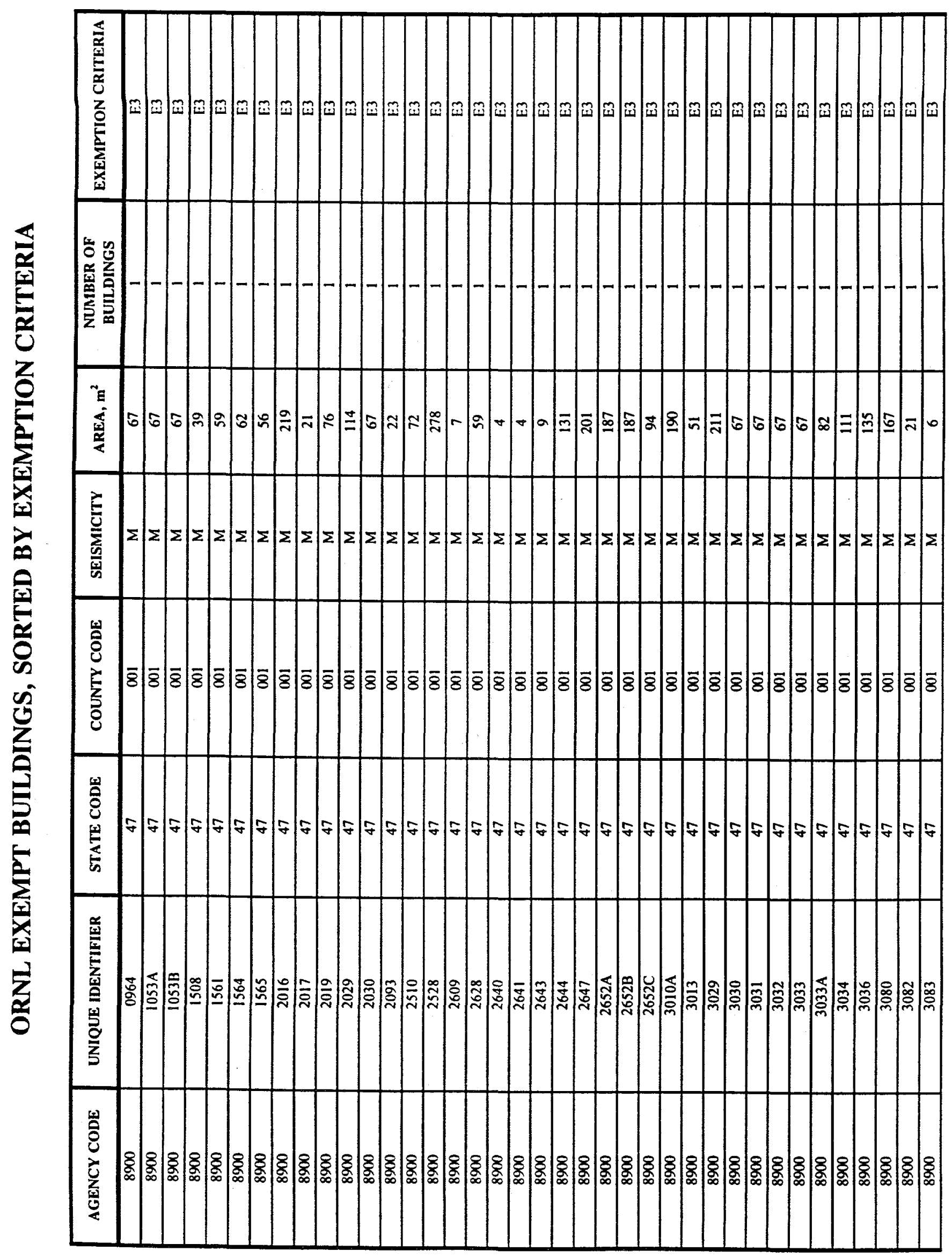




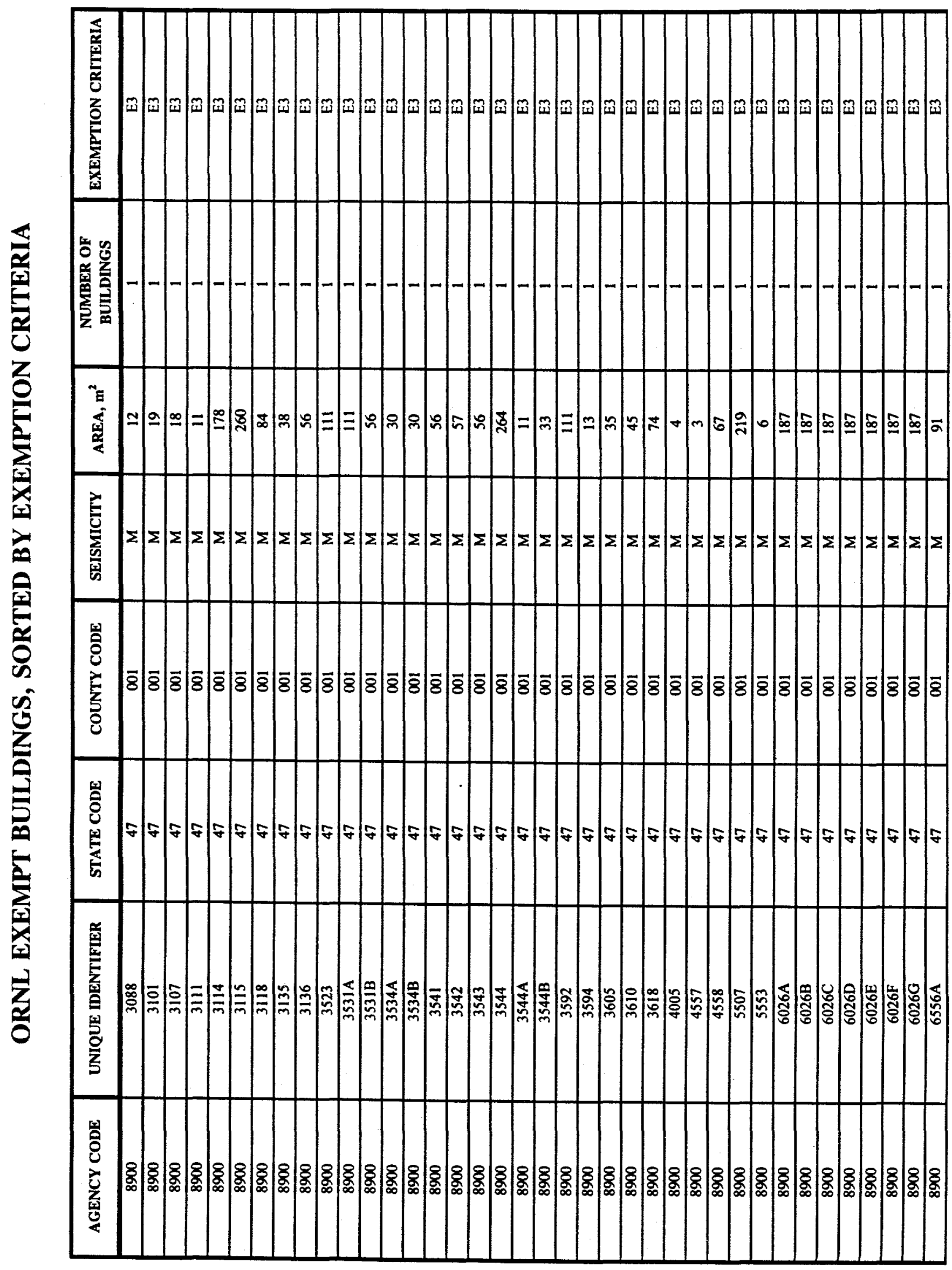







ORNL EXEMPT BUILDINGS, SORTED BY EXEMPTION CRITERIA

\begin{tabular}{|c|c|c|c|c|c|c|c|}
\hline AGENCY CODE & UNIQUE IDENTIFIER & STATE CODE & COUNTY CODE & SEISMICITY & AREA, $\mathbf{m}^{2}$ & $\begin{array}{l}\text { NUMBER OF } \\
\text { BUILDINGS }\end{array}$ & EXEMPTION CRITERIA \\
\hline 8900 & 7083 & 47 & 001 & $M$ & 27 & 1 & E3 \\
\hline 8900 & 7505 & 47 & 001 & $\mathbf{M}$ & 274 & 1 & E3 \\
\hline 8900 & $7554 \mathrm{~A}$ & 47 & 001 & $\mathbf{M}$ & 67 & 1 & E3 \\
\hline 8900 & $7666 \mathrm{~A}$ & 47 & 001 & $\bar{M}$ & 67 & 1 & E3 \\
\hline 8900 & 7712 & 47 & 001 & $\bar{M}$ & 104 & 1 & E3 \\
\hline 8900 & 7751 & 47 & 001 & $\bar{M}$ & 6 & 1 & $\overline{E 3}$ \\
\hline 8900 & 7752 & 47 & 001 & $\bar{M}$ & 7 & 1 & E3 \\
\hline 8900 & $7802 \mathrm{C}$ & 47 & 001 & $\mathrm{M}$ & 16 & 1 & E3 \\
\hline 8900 & $7802 \mathrm{D}$ & 47 & 001 & $\mathbf{M}$ & 14 & 1 & E3 \\
\hline 8900 & $7802 \mathrm{~F}$ & 47 & 001 & $\bar{M}$ & 46 & 1 & E3 \\
\hline 8900 & 7803 & 47 & 001 & $M$ & 18 & 1 & E3 \\
\hline 8900 & 7819 & 47 & 001 & $\mathbf{M}$ & 204 & 1 & $\overline{\mathrm{E} 3}$ \\
\hline 8900 & $7824 \mathrm{~A}$ & 47 & 001 & M & 28 & 1 & E3 \\
\hline 8900 & $7841 \mathrm{~A}$ & 47 & 001 & $\mathbf{M}$ & 67 & 1 & E3 \\
\hline 8900 & 7847 & 47 & 001 & $\mathbf{M}$ & 9 & 1 & $\mathrm{E} 3$ \\
\hline 8900 & 7857 & 47 & 001 & $\mathbf{M}$ & 139 & 1 & E3 \\
\hline 8900 & $7859 \mathrm{~B}$ & 47 & 001 & $\mathbf{M}$ & 5 & 1 & E3 \\
\hline 8900 & 7863 & 47 & 001 & $\mathbf{M}$ & 255 & 1 & E3 \\
\hline 8900 & 7875 & 47 & 001 & $\mathbf{M}$ & 45 & 1 & $\overline{\mathrm{E} 3}$ \\
\hline 8900 & 7876 & 47 & 001 & $\mathbf{M}$ & 22 & 1 & E3 \\
\hline 8900 & 7881 & 47 & 001 & $\bar{M}$ & 4 & 1 & E3 \\
\hline 8900 & 7912 & 47 & 001 & $\mathbf{M}$ & 168 & 1 & $\mathrm{E} 3$ \\
\hline 8900 & 7914 & 47 & 001 & $\mathbf{M}$ & 220 & 1 & E3 \\
\hline 8900 & $7914 A$ & 47 & 001 & $M$ & 84 & 1 & E3 \\
\hline 8900 & 7915 & 47 & 001 & $M$ & 220 & 1 & E3 \\
\hline 8900 & 7919 & 47 & 001 & $\mathbf{M}$ & 24 & 1 & $\bar{E} 3$ \\
\hline 8900 & 7922 & 47 & 001 & $M$ & 121 & 1 & E3 \\
\hline 8900 & 7933 & 47 & 001 & $\mathbf{M}$ & 56 & 1 & E3 \\
\hline 8900 & 7935 & 47 & 001 & $\mathbf{M}$ & 232 & 1 & E3 \\
\hline 8900 & $7953 \mathrm{~A}$ & 47 & 001 & $M$ & 67 & 1 & E3 \\
\hline 8900 & $7953 \mathrm{~B}$ & 47 & 001 & $\mathbf{M}$ & 62 & 1 & E3 \\
\hline 8900 & $7953 \mathrm{C}$ & 47 & 001 & $\mathrm{M}$ & 67 & 1 & E3 \\
\hline 8900 & 7955 & 47 & 001 & $\mathbf{M}$ & 4 & 1 & E3 \\
\hline 8900 & 7957 & 47 & 001 & $M$ & 56 & 1 & E3 \\
\hline 8900 & 7958 & 47 & 001 & $M$ & 6 & 1 & E3 \\
\hline 8900 & $7964 \mathrm{~A}$ & 47 & 001 & $M$ & 201 & 1 & E3 \\
\hline 8900 & $7964 \mathrm{~B}$ & 47 & 001 & $\mathbf{M}$ & 201 & 1 & E3 \\
\hline 8900 & $7964 C$ & 47 & 001 & $\mathbf{M}$ & 201 & 1 & E3 \\
\hline
\end{tabular}




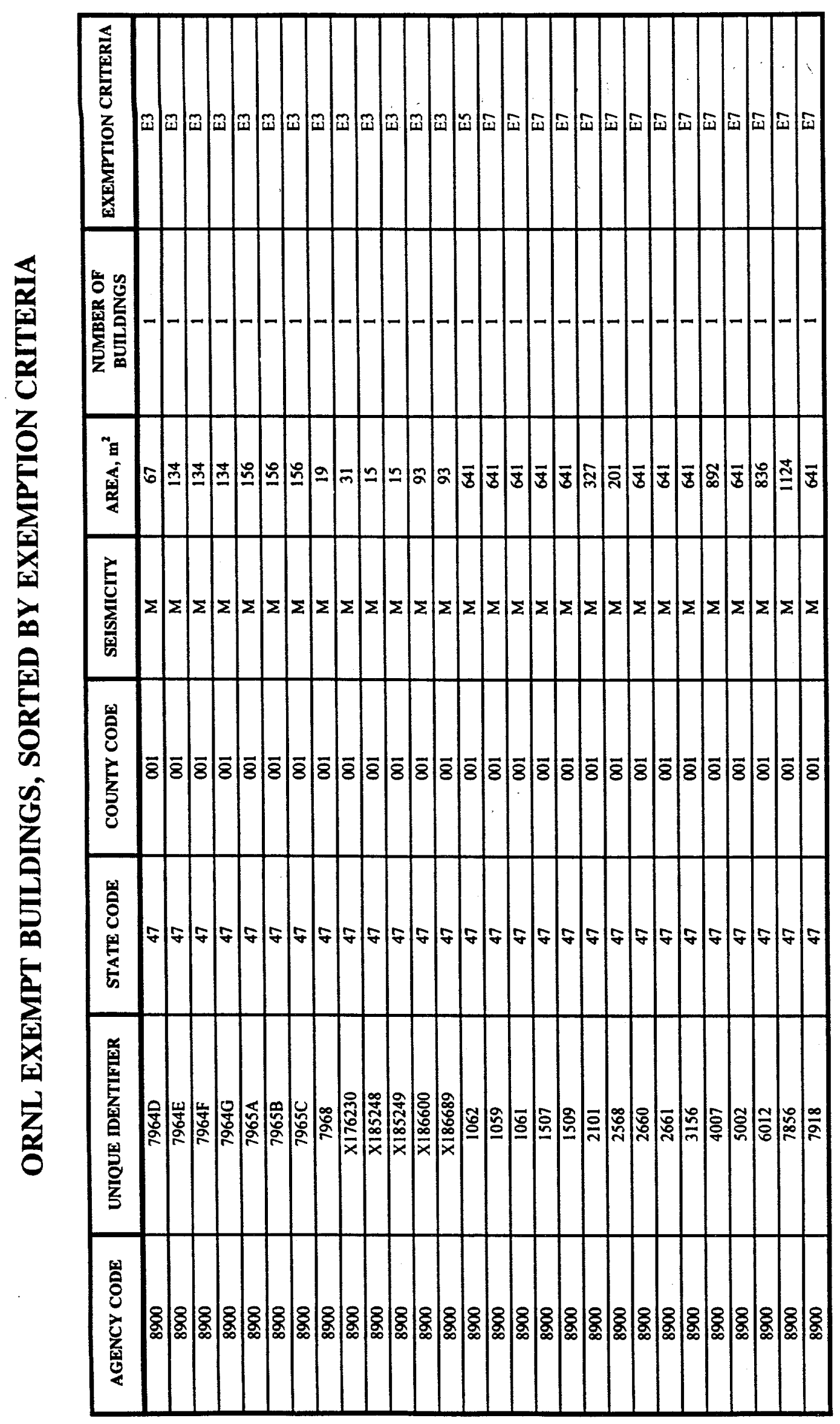




\author{
APPENDIX D \\ ORNL NON-EXEMPT, NON-EVALUATED BUILDINGS
}


ORNL NON-EXEMPT, NON-EVALUATED BUILDINGS, SORTED BY MODEL BUILDING TYPE AND BUILDING NUMBER

\begin{tabular}{|c|c|c|c|c|c|c|c|}
\hline AGENCY CODE & 8900 & 8900 & 8900 & 8900 & 8900 & 8900 & 8900 \\
\hline UNIQUE DENTIFIER & 2008 & 2013 & 2018 & 2069 & 2506 & 2517 & $3026 C$ \\
\hline STATE CODE & 47 & 47 & 47 & 47 & 47 & 47 & 47 \\
\hline COUNTY CODE & 001 & 001 & 001 & 001 & 001 & 001 & 001 \\
\hline SEISMICITY & $M$ & $M$ & $M$ & $\mathbf{M}$ & $\mathbf{M}$ & $\mathbf{M}$ & $\mathbf{M}$ \\
\hline AREA, $\mathbf{m}^{2}$ & 451 & 1067 & 591 & 652 & 815 & 441 & 2247 \\
\hline NUMBER OF BUILDINGS & 1 & 1 & 1 & 1 & 1 & 1 & 1 \\
\hline EXEMPTION CRITERIA & E0 & E0 & E0 & E0 & E0 & E0 & E0 \\
\hline OCCUPANCY CLASS & 50 & 50 & 50 & 29 & 50 & 10 & 70 \\
\hline ESSENTIAL DESIGNATION & P2 & P1 & PI & P1 & P1 & P1 & $\mathrm{P} 2$ \\
\hline HISTORIC DESIGNATION & $\mathrm{H} 2$ & $\mathrm{H} 2$ & $\mathrm{H} 2$ & $\mathrm{H} 2$ & $\mathrm{H2}$ & $\mathrm{H2}$ & $\mathbf{H 2}$ \\
\hline DATE OF CONSTRUCTION & 1946 & 1943 & 1943 & 1943 & 1943 & 1943 & 1943 \\
\hline MODEL BUILDING TYPE & MB02 & MB02 & $\mathrm{MB02}$ & $\mathrm{MB02}$ & MB02 & $\mathrm{MBO2}$ & $\mathrm{MB} 02$ \\
\hline NUMBER OF STORIES & N01 & N01 & N01 & No1 & No1 & No1 & N01 \\
\hline \multicolumn{8}{|l|}{ EHR DESIGNATION } \\
\hline \multicolumn{8}{|l|}{ EVALUATION PROCEDURE USED } \\
\hline \multicolumn{8}{|l|}{ SOIL TYPE } \\
\hline \multicolumn{8}{|l|}{ FOUNDATION TYPE } \\
\hline \multicolumn{8}{|l|}{ OUTCOME OF EVALUATON } \\
\hline \multicolumn{8}{|c|}{ STRUCTURAL DEFCIENCY DETERMINATION } \\
\hline \multicolumn{8}{|c|}{ NONSTRUCTURAL DEFCIENCY DETERMINATION } \\
\hline \multicolumn{8}{|c|}{ GEOLOGIC/SITE HAZARD DEFICIENCY DETERMINATION } \\
\hline \multicolumn{8}{|c|}{ ADJACENCY PROBLEM DETERMINATION } \\
\hline \multicolumn{8}{|l|}{ STRUCTURAL COSTS } \\
\hline \multicolumn{8}{|l|}{ NONSTRUCTURAL COSTS } \\
\hline \multicolumn{8}{|l|}{ FINISHING COSTS } \\
\hline \multicolumn{8}{|l|}{ PROJECT COSTS } \\
\hline \multicolumn{8}{|l|}{ SOURCE OF COST ESTIMATE } \\
\hline COMMENTS & & & & & & & \\
\hline
\end{tabular}


ORNL NON-EXEMPT, NON-EVALUATED BUILDINGS, SORTED BY MODEL BUILDING TYPE AND BUILDING NUMBER

\begin{tabular}{|c|c|c|c|c|c|c|c|}
\hline AGENCY CODE & 8900 & 8900 & 8900 & 8900 & 8900 & 8900 & 8900 \\
\hline UNIQUE IDENTIFIER & $3026 \mathrm{D}$ & 3074 & 3550 & 6003 & $\underline{0902}$ & 1503 & 2000 \\
\hline STATE CODE & 47 & 47 & 47 & 47 & 47 & 47 & 47 \\
\hline COUNTY CODE & 001 & 001 & 001 & 001 & 001 & 001 & 001 \\
\hline SEISMICITY & $\mathrm{M}$ & $\mathbf{M}$ & $\mathbf{M}$ & $\mathrm{M}$ & $\mathrm{M}$ & $\mathbf{M}$ & $\mathrm{M}$ \\
\hline AREA, $m^{2}$ & 2247 & 293 & 1145 & 681 & 375 & 890 & 2107 \\
\hline NUMBER OF BUILDINGS & 1 & 1 & 1 & 1 & 1 & 1 & 1 \\
\hline EXEMPTION CRTTERIA & E0 & E0 & E0 & EO & E0 & E0 & EO \\
\hline OCCUPANCY CLASS & 70 & 50 & 70 & 10 & 70 & 70 & 50 \\
\hline ESSENTIAL DESIGNATION & $\mathrm{P1}$ & PI & P1 & $\mathrm{Pl}$ & P1 & P1 & P1 \\
\hline HISTORIC DESIGNATION & $\mathrm{H} 2$ & $\mathrm{H} 2$ & $\mathrm{H} 2$ & $\mathrm{H} 2$ & $\mathrm{H} 2$ & $\mathrm{H} 2$ & $\mathrm{H} 2$ \\
\hline DATE OF CONSTRUCTION & 1945 & 1951 & 1943 & 1976 & 1948 & 1965 & 1948 \\
\hline MODEL BUILDING TYPE & MB02 & MB02 & $\mathrm{MBO2}$ & MB02 & $\mathrm{MB03}$ & MB03 & $\mathrm{MB03}$ \\
\hline NUMBER OF STORIES & N01 & N01 & $\mathrm{N} 01$ & N02 & N01 & N01 & N01 \\
\hline \multicolumn{8}{|l|}{ EHR DESIGNATION } \\
\hline \multicolumn{8}{|c|}{ EVALUATION PROCEDURE USED } \\
\hline \multicolumn{8}{|l|}{ SOIL TYPE } \\
\hline \multicolumn{8}{|l|}{ FOUNDATION TYPE } \\
\hline \multicolumn{8}{|l|}{ OUTCOME OF EVALUATON } \\
\hline \multicolumn{8}{|c|}{ STRUCTURAL DEFCIENCY DETERMINATION } \\
\hline \multicolumn{8}{|c|}{ NONSTRUCTURAL DEFCIENCY DETERMINATION } \\
\hline \multicolumn{8}{|c|}{ GEOLOGIC/STTE HAZARD DEFICIENCY DETERMINATION } \\
\hline \multicolumn{8}{|c|}{ ADJACENCY PROBLEM DETERMINATION } \\
\hline \multicolumn{8}{|l|}{ STRUCTURAL COSTS } \\
\hline \multicolumn{8}{|l|}{ NONSTRUCTURAL COSTS } \\
\hline \multicolumn{8}{|l|}{ FINISHING COSTS } \\
\hline \multicolumn{8}{|l|}{ PROJECT COSTS } \\
\hline \multicolumn{8}{|l|}{ SOURCE OF COST ESTTMATE } \\
\hline COMMENTS & & & & & & & \\
\hline
\end{tabular}


ORNL NON-EXEMPT, NON-EVALUATED BUILDINGS, SORTED BY MODEL BUILDING TYPE AND BUILDING NUMBER

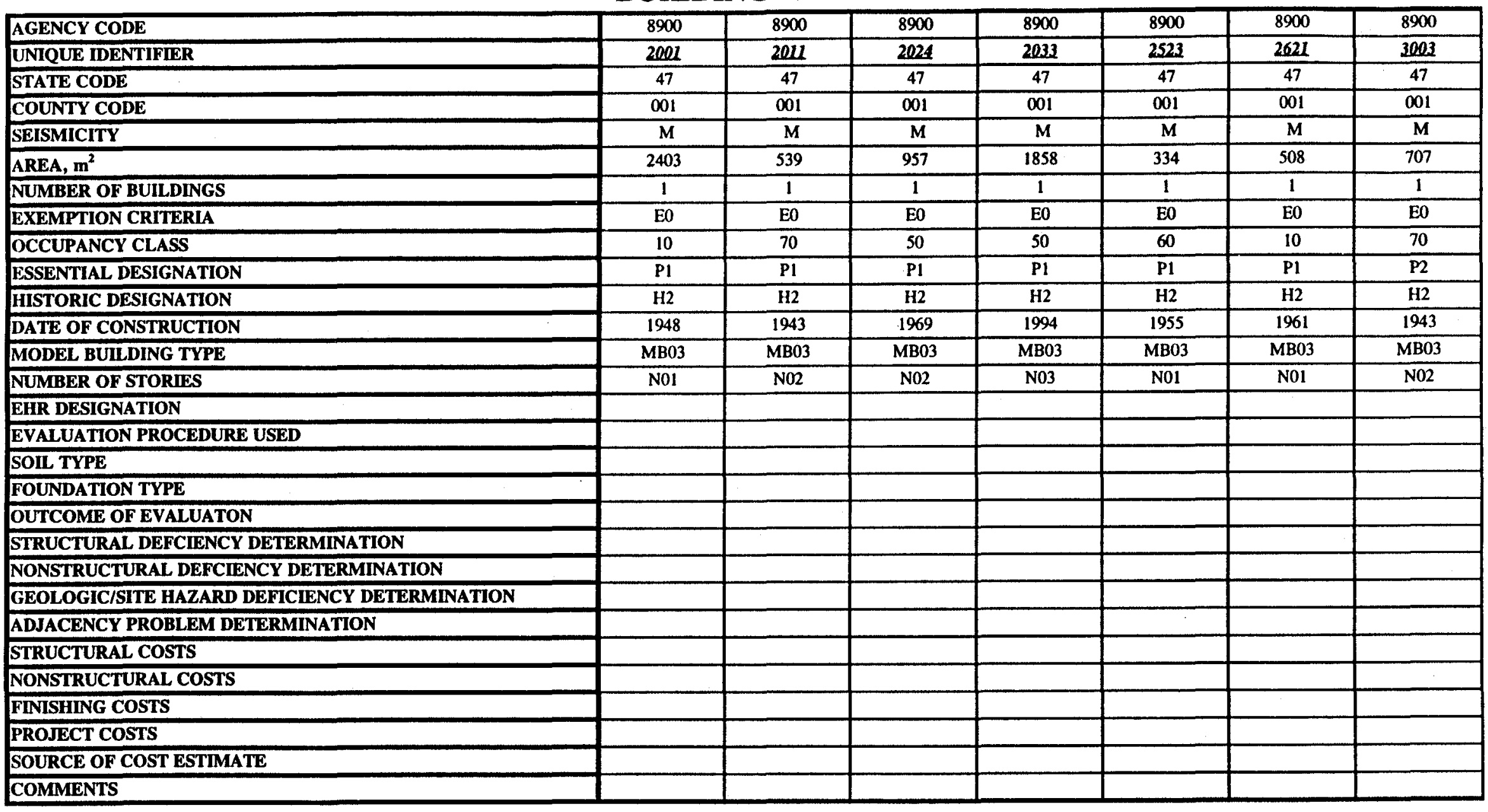


ORNL NON-EXEMPT, NON-EVALUATED BUILDINGS, SORTED BY MODEL BUILDING TYPE AND BUILDING NUMBER

\begin{tabular}{|c|c|c|c|c|c|c|c|}
\hline$\triangle \triangle A G N C Y$ CODE & 8900 & 8900 & 8900 & 8900 & 8900 & 8900 & 8900 \\
\hline UNIQUE IDENTIFIER & 3044 & 3047 & 3025 & 3104 & 3144 & 3147 & 3150 \\
\hline STATE CODE & 47 & 47 & 47 & 47 & 47 & 47 & 47 \\
\hline COUNTY CODE & 001 & 001 & 001 & 001 & $\mathbf{0 0 1}$ & 001 & 001 \\
\hline SEISMICITY & $\mathbf{M}$ & $M$ & $M$ & $M$ & $M$ & $\mathbf{M}$ & $M$ \\
\hline AREA, $\mathrm{m}^{2}$ & 284 & 2381 & 651 & 681 & 650 & 1003 & 1087 \\
\hline NUMBER OF BUILDINGS & 1 & 1 & 1 & 1 & 1 & 1 & 1 \\
\hline EXEMPTION CRITERIA & E0 & EO & EO & E0 & E0 & EO & E0 \\
\hline OCCUPANCY CLASS & 50 & 70 & 50 & 50 & 70 & 10 & 70 \\
\hline ESSENTIAL DESIGNATION & $\overline{P 1}$ & $\overline{P 3}$ & PI & $\mathbf{P 1}$ & P1 & $\mathbf{P 1}$ & P1 \\
\hline HISTORIC DESIGNATION & $\mathrm{H}^{2}$ & $\mathrm{H2}$ & $\mathrm{H2}$ & $\mathrm{H} 2$ & $\mathrm{H} 2$ & $\mathrm{H} 2$ & $\mathrm{H} 2$ \\
\hline DATE OF CONSTRUCTION & 1955 & 1963 & 1959 & 1961 & 1987 & 1988 & 1995 \\
\hline MODEL BUILDING TYPE & MB03 & MB03 & MB03 & $\mathrm{MB03}$ & $\mathrm{MB03}$ & MB03 & $\mathrm{MB03}$ \\
\hline NUMBER OF STORIES & N01 & N03 & N01 & N01 & N01 & N02 & N02 \\
\hline \multicolumn{8}{|l|}{ EHR DESIGNATION } \\
\hline \multicolumn{8}{|c|}{ EVALUATION PROCEDURE USED } \\
\hline \multicolumn{8}{|l|}{ SOIL TYPE } \\
\hline \multicolumn{8}{|l|}{ FOUNDATION TYPE } \\
\hline \multicolumn{8}{|l|}{ OUTCOME OF EVALUATON } \\
\hline \multicolumn{8}{|c|}{ STRUCTURAL DEFCIENCY DETERMINATION } \\
\hline \multicolumn{8}{|c|}{ NONSTRUCTURAL DEFCIENCY DETERMINATION } \\
\hline \multicolumn{8}{|c|}{ GEOLOGIC/SITE HAZARD DEFICIENCY DETERMINATION } \\
\hline \multicolumn{8}{|c|}{ ADJACENCY PROBLEM DETERMINATION } \\
\hline \multicolumn{8}{|l|}{ STRUCTURAL COSTS } \\
\hline \multicolumn{8}{|l|}{ NONSTRUCTURAL COSTS } \\
\hline \multicolumn{8}{|l|}{ FINISHING COSTS } \\
\hline \multicolumn{8}{|l|}{ PROJECT COSTS } \\
\hline \multicolumn{8}{|l|}{ SOURCE OF COST ESTIMATE } \\
\hline COMMENTS & & & & & & & \\
\hline
\end{tabular}


ORNL NON-EXEMPT, NON-EVALUATED BUILDINGS, SORTED BY MODEL BUILDING TYPE AND BUILDING NUMBER

\begin{tabular}{|c|c|c|c|c|c|c|c|}
\hline AGENCY CODE & 8900 & 8900 & 8900 & 8900 & 8900 & 8900 & 8900 \\
\hline UNIQUE IDENTIFIER & 3508 & 3525 & 3582 & 3608 & 5510 & 55104 & 6011 \\
\hline STATE CODE & 47 & 47 & 47 & 47 & 47 & 47 & 47 \\
\hline COUNTY CODE & 001 & 001 & 001 & 001 & 001 & 001 & 001 \\
\hline SEISMICITY & $\mathbf{M}$ & $\mathbf{M}$ & $\mathbf{M}$ & $\mathbf{M}$ & $\mathbf{M}$ & $\mathbf{M}$ & $\mathbf{M}$ \\
\hline AREA, $\mathbf{m}^{2}$ & 1296 & 2466 & 316 & 1821 & 585 & 684 & 859 \\
\hline NUMBER OF BUILDINGS & 1 & 1 & 1 & 1 & 1 & 1 & 1 \\
\hline EXEMPTION CRITERIA & E0 & E0 & E0 & E0 & E0 & E0 & E0 \\
\hline OCCUPANCY CLASS & 50 & 70 & 50 & 50 & 70 & 70 & 10 \\
\hline ESSENTIAL DESIGNATION & P2 & $\mathbf{P 3}$ & $\mathbf{P 1}$ & P1 & P1 & P1 & P1 \\
\hline HISTORIC DESIGNATION & $\mathrm{H} 2$ & $\mathrm{H} 2$ & H2 & H2 & $\mathrm{H} 2$ & $\mathrm{H} 2$ & $\mathrm{H} 2$ \\
\hline DATE OF CONSTRUCTION & 1951 & 1963 & 1950 & 1989 & 1989 & 1991 & 1989 \\
\hline MODEL BUILDING TYPE & $\mathrm{MB03}$ & MB03 & $\mathrm{MB03}$ & MB03 & MB03 & MB03 & MB03 \\
\hline NUMBER OF STORIES & N01 & N01 & N01 & N01 & N01 & N01 & N02 \\
\hline \multicolumn{8}{|l|}{ EHR DESIGNATION } \\
\hline \multicolumn{8}{|c|}{ EVALUATION PROCEDURE USED } \\
\hline \multicolumn{8}{|l|}{ SOIL TYPE } \\
\hline \multicolumn{8}{|l|}{ FOUNDATION TYPE } \\
\hline \multicolumn{8}{|l|}{ OUTCOME OF EVALUATON } \\
\hline \multicolumn{8}{|c|}{ STRUCTURAL DEFCIENCY DETERMINATION } \\
\hline \multicolumn{8}{|c|}{ NONSTRUCTURAL DEFCIENCY DETERMINATION } \\
\hline \multicolumn{8}{|c|}{ GEOLOGIC/SITE HAZARD DEFICIENCY DETERMINATION } \\
\hline \multicolumn{8}{|c|}{ ADJACENCY PROBLEM DETERMINATION } \\
\hline \multicolumn{8}{|l|}{ STRUCTURAL COSTS } \\
\hline \multicolumn{8}{|l|}{ NONSTRUCTURAL COSTS } \\
\hline \multicolumn{8}{|l|}{ FINISHING COSTS } \\
\hline \multicolumn{8}{|l|}{ PROJECT COSTS } \\
\hline \multicolumn{8}{|l|}{ SOURCE OF COST ESTIMATE } \\
\hline COMMENTS & & & & & & & \\
\hline
\end{tabular}


ORNL NON-EXEMPT, NON-EVALUATED BUILDINGS, SORTED BY MODEL BUILDING TYPE AND BUILDING NUMBER

\begin{tabular}{|c|c|c|c|c|c|c|c|}
\hline AGENCY CODE & 8900 & 8900 & 8900 & 8900 & 8900 & 8900 & 8900 \\
\hline UNIQUE IDENTIFIER & 2001 & 2002 & 2003 & 2005 & 2002 & 7018 & 2032 \\
\hline STATE CODE & 47 & 47 & 47 & 47 & 47 & 47 & 47 \\
\hline COUNTY CODE & 001 & 001 & 001 & 001 & 001 & 001 & 001 \\
\hline SEISMICITY & $\mathbf{M}$ & $M$ & $\mathbf{M}$ & $M$ & $M$ & $\mathbf{M}$ & $\mathbf{M}$ \\
\hline AREA, $\mathbf{m}^{2}$ & 4113 & 2626 & 462 & 414 & 333 & 1858 & 929 \\
\hline NUMBER OF BUILDINGS & 1 & 1 & 1 & 1 & 1 & 1 & 1 \\
\hline EXEMPTION CRITERIA & E0 & E0 & EO & E0 & E0 & E0 & E0 \\
\hline OCCUPANCY CLASS & 60 & 50 & 50 & 50 & 50 & 50 & 50 \\
\hline ESSENTIAL DESIGNATION & P1 & P1 & P1 & P1 & P1 & P1 & $\mathbf{P 1}$ \\
\hline HISTORIC DESIGNATION & $\mathrm{H} 2$ & $\mathrm{H} 2$ & $\mathbf{H} \mathbf{2}$ & $\mathrm{H} 2$ & $\mathrm{H2}$ & $\mathbf{H} 2$ & $\mathrm{H} 2$ \\
\hline DATE OF CONSTRUCTION & 1948 & 1948 & 1948 & 1948 & 1948 & 1959 & 1986 \\
\hline MODEL BULDING TYPE & MB03 & $\mathrm{MB03}$ & MB03 & MB03 & MB03 & MB03 & $\mathrm{MB03}$ \\
\hline NUMBER OF STORIES & N01 & N01 & N01 & N01 & N01 & N01 & N01 \\
\hline \multicolumn{8}{|l|}{ EHR DESIGNATION } \\
\hline \multicolumn{8}{|c|}{ EVALUATION PROCEDURE USED } \\
\hline \multicolumn{8}{|l|}{ SOIL TYPE } \\
\hline \multicolumn{8}{|l|}{ FOUNDATION TYPE } \\
\hline \multicolumn{8}{|l|}{ OUTCOME OF EVALUATON } \\
\hline \multicolumn{8}{|c|}{ STRUCTURAL DEFCIENCY DETERMINATION } \\
\hline \multicolumn{8}{|c|}{ NONSTRUCTURAL DEFCIENCY DETERMINATION } \\
\hline \multicolumn{8}{|c|}{ GEOLOGIC/SITE HAZARD DEFICIENCY DETERMINATION } \\
\hline \multicolumn{8}{|c|}{ ADJACENCY PROBLEM DETERMINATION } \\
\hline \multicolumn{8}{|l|}{ STRUCTURAL COSTS } \\
\hline \multicolumn{8}{|l|}{ NONSTRUCTURAL COSTS } \\
\hline \multicolumn{8}{|l|}{ FINISHING COSTS } \\
\hline \multicolumn{8}{|l|}{ PROJECT COSTS } \\
\hline \multicolumn{8}{|l|}{ SOURCE OF COST ESTIMATE } \\
\hline COMMENTS & & & & & & & \\
\hline
\end{tabular}


ORNL NON-EXEMPT, NON-EVALUATED BUILDINGS, SORTED BY MODEL BUILDING TYPE AND BUILDING NUMBER

\begin{tabular}{|c|c|c|c|c|c|c|c|}
\hline AGENCY CODE & 8900 & 8900 & 8900 & 8900 & 8900 & 8900 & 8900 \\
\hline UNIQUE IDENTIFER & 2516 & 2555 & $\underline{\mathbf{Z 6 5 2}}$ & 2653 & $\underline{2654}$ & 2823 & 28311 \\
\hline STATE CODE & 47 & 47 & 47 & 47 & 47 & 47 & 47 \\
\hline COUNTY CODE & 001 & 001 & 001 & 001 & 001 & 001 & 001 \\
\hline SEISMICITY & $\mathbf{M}$ & $\mathbf{M}$ & $M$ & $\mathbf{M}$ & $\mathbf{M}$ & $\mathbf{M}$ & $M$ \\
\hline AREA, $\mathbf{m}^{2}$ & 374 & 445 & 223 & 279 & 149 & 372 & 107 \\
\hline NUMBER OF BUILDINGS & 1 & 1 & 1 & 1 & 1 & 1 & 1 \\
\hline EXEMPTION CRITERIA & E0 & E0 & E0 & E0 & E0 & E0 & E0 \\
\hline OCCUPANCY CLASS & 50 & 50 & 40 & 40 & 40 & 40 & 40 \\
\hline ESSENTIAL DESIGNATION & $\mathbf{P 1}$ & P2 & P3 & P3 & P3 & P3 & $\mathrm{P2}$ \\
\hline HISTORIC DESIGNATION & $\mathrm{H} 2$ & $\mathrm{H} 2$ & $\mathrm{H} 2$ & $\mathrm{H2}$ & $\mathbf{H 2}$ & $\mathrm{H} 2$ & $\mathbf{H} 2$ \\
\hline DATE OF CONSTRUCTION & 1967 & 1961 & 1987 & 1987 & 1988 & 1972 & 1978 \\
\hline MODEL BULDING TYPE & MB03 & $\mathrm{MB03}$ & $\mathrm{MB03}$ & MB03 & MB03 & MB03 & $\mathrm{MB03}$ \\
\hline NUMBER OF STORIES & No1 & N01 & N01 & N01 & N01 & N01 & No1 \\
\hline \multicolumn{8}{|l|}{ EHR DESIGNATION } \\
\hline \multicolumn{8}{|c|}{ EVALUATION PROCEDURE USED } \\
\hline \multicolumn{8}{|l|}{ SOIL TYPE } \\
\hline \multicolumn{8}{|l|}{ FOUNDATION TYPE } \\
\hline \multicolumn{8}{|l|}{ OUTCOME OF EVALUATON } \\
\hline \multicolumn{8}{|c|}{ STRUCTURAL DEFCIENCY DETERMINATION } \\
\hline \multicolumn{8}{|c|}{ NONSTRUCTURAL DEFCIENCY DETERMINATION } \\
\hline \multicolumn{8}{|c|}{ GEOLOGIC/SITE HAZARD DEFICIENCY DETERMINATION } \\
\hline \multicolumn{8}{|c|}{ ADJACENCY PROBLEM DETERMINATION } \\
\hline \multicolumn{8}{|l|}{ STRUCTURAL COSTS } \\
\hline \multicolumn{8}{|l|}{ NONSTRUCTURAL COSTS } \\
\hline \multicolumn{8}{|l|}{ FINISHING COSTS } \\
\hline \multicolumn{8}{|l|}{ PROJECT COSTS } \\
\hline \multicolumn{8}{|l|}{ SOURCE OF COST ESTIMATE } \\
\hline COMMENTS & & & & & & & \\
\hline
\end{tabular}


ORNL NON-EXEMPT, NON-EVALUATED BUILDINGS, SORTED BY MODEL BUILDING TYPE AND BUILDING NUMBER

\begin{tabular}{|c|c|c|c|c|c|c|c|}
\hline AGENCY CODE & 8900 & 8900 & 8900 & 8900 & 8900 & 8900 & 8900 \\
\hline UNIQUE IDENTIFIER & 2878 & 7872 & 2936 & 2962 & 2966 & 3001 & 3005 \\
\hline STATE CODE & 47 & 47 & 47 & 47 & 47 & 47 & 47 \\
\hline COUNTY CODE & 001 & 001 & 001 & $\infty 01$ & 001 & 001 & 001 \\
\hline SEISMICITY & $\mathbf{M}$ & $\mathbf{M}$ & $M$ & $\mathbf{M}$ & $\mathbf{M}$ & $\mathbf{M}$ & $M$ \\
\hline AREA, $\mathrm{m}^{2}$ & 331 & 383 & 372 & 519 & 465 & 2763 & 1056 \\
\hline NUMBER OF BULDINGS & 1 & 1 & 1 & 1 & 1 & 1 & 1 \\
\hline EXEMPTION CRITERIA & E0 & EO & E0 & E0 & E0 & E0 & E0 \\
\hline OCCUPANCY CLASS & 50 & 50 & 40 & 10 & 50 & 80 & 70 \\
\hline ESSENTIAL DESIGNATION & $\mathbf{P 2}$ & P2 & P1 & P1 & P3 & P1 & $\mathrm{P2}$ \\
\hline HISTORIC DESIGNATION & $\mathrm{H} \mathbf{2}$ & $\mathrm{H} 2$ & $\mathbf{H 2}$ & $\mathbf{H 2}$ & $\mathrm{H} 2$ & $\mathrm{HI}$ & H2 \\
\hline DATE OF CONSTRUCTION & 1987 & 1991 & 1993 & 1988 & 1977 & 1943 & 1948 \\
\hline MODEL BUILDING TYPE & $\mathrm{MB} 03$ & $\mathrm{MB03}$ & $\mathrm{MB03}$ & $\mathrm{MB03}$ & $\mathrm{MBO3}$ & MB04 & MB04 \\
\hline NUMBER OF STORIES & NO1 & N01 & N01 & N02 & N01 & No3 & No1 \\
\hline \multicolumn{8}{|l|}{ EHR DESIGNATION } \\
\hline \multicolumn{8}{|c|}{ EVALUATION PROCEDURE USED } \\
\hline \multicolumn{8}{|l|}{ SOIL TYPE } \\
\hline \multicolumn{8}{|l|}{ FOUNDATION TYPE } \\
\hline \multicolumn{8}{|l|}{ OUTCOME OF EVALUATON } \\
\hline \multicolumn{8}{|c|}{ STRUCTURAL DEFCIENCY DETERMINATION } \\
\hline \multicolumn{8}{|c|}{ NONSTRUCTURAL DEFCIENCY DETERMINATION } \\
\hline \multicolumn{8}{|c|}{ GEOLOGIC/SITE HAZARD DEFICIENCY DETERMINATION } \\
\hline \multicolumn{8}{|c|}{ ADJACENCY PROBLEM DETERMINATION } \\
\hline \multicolumn{8}{|l|}{ STRUCTURAL COSTS } \\
\hline \multicolumn{8}{|l|}{ NONSTRUCTURAL COSTS } \\
\hline \multicolumn{8}{|l|}{ FINISHING COSTS } \\
\hline \multicolumn{8}{|l|}{ PROJECT COSTS } \\
\hline \multicolumn{8}{|l|}{ SOURCE OF COST ESTMMATE } \\
\hline COMMENTS & & & & & & & \\
\hline
\end{tabular}


ORNL NON-EXEMPT, NON-EVALUATED BUILDINGS, SORTED BY MODEL BUILDING TYPE AND BUILDING NUMBER

\begin{tabular}{|c|c|c|c|c|c|c|c|}
\hline AGENCY CODE & 8900 & 8900 & 8900 & 8900 & 8900 & 8900 & 8900 \\
\hline UNIQUE IDENTIFIER & 3010 & 3012 & 3028 & 3042 & 3137 & 3502 & 3503 \\
\hline STATE CODE & 47 & 47 & 47 & 47 & 47 & 47 & 47 \\
\hline COUNTY CODE & 001 & 001 & 001 & 001 & 001 & 001 & 001 \\
\hline SEISMICITY & $\mathbf{M}$ & $M$ & $\mathbf{M}$ & $\mathbf{M}$ & $\mathbf{M}$ & $\mathbf{M}$ & $\mathbf{M}$ \\
\hline AREA, $\mathrm{m}^{2}$ & 792 & 1003 & 1584 & 3472 & 595 & 1127 & 1134 \\
\hline NUMBER OF BUILDINGS & 1 & 1 & 1 & 1 & 1 & 1 & 1 \\
\hline EXEMPTION CRITERIA & E0 & E0 & E0 & E0 & E0 & E0 & E0 \\
\hline OCCUPANCY CLASS & 70 & 50 & 70 & 70 & 70 & 50 & 70 \\
\hline ESSENTLAL DESIGNATION & $\mathbf{P 3}$ & P1 & $\mathbf{P 1}$ & $\mathbf{P 2}$ & P1 & P1 & P1 \\
\hline HISTORIC DESIGNATION & $\mathrm{H2}$ & $\mathrm{H} 2$ & $\mathrm{H2}$ & $\mathbf{H 2}$ & $\mathrm{H} 2$ & $\mathbf{H 2}$ & $\mathrm{H} 2$ \\
\hline DATE OF CONSTRUCTION & 1950 & 1947 & 1951 & 1955 & 1984 & 1950 & 1948 \\
\hline MODEL BUILDING TYPE & MB04 & MB04 & MB04 & MB04 & MB04 & MB04 & MB04 \\
\hline NUMBER OF STORIES & N01 & N01 & N01 & N01 & N02 & N01 & N01 \\
\hline \multicolumn{8}{|l|}{ EHR DESIGNATION } \\
\hline \multicolumn{8}{|c|}{ EVALUATION PROCEDURE USED } \\
\hline \multicolumn{8}{|l|}{ SOIL TYPE } \\
\hline \multicolumn{8}{|l|}{ FOUNDATION TYPE } \\
\hline \multicolumn{8}{|l|}{ OUTCOME OF EVALUATON } \\
\hline \multicolumn{8}{|c|}{ STRUCTURAL DEFCIENCY DETERMINATION } \\
\hline \multicolumn{8}{|c|}{ NONSTRUCTURAL DEFCIENCY DETERMINATION } \\
\hline \multicolumn{8}{|c|}{ GEOLOGIC/SITE HAZARD DEFICIENCY DETERMINATION } \\
\hline \multicolumn{8}{|c|}{ ADJACENCY PROBLEM DETERMINATION } \\
\hline \multicolumn{8}{|l|}{ STRUCTURAL COSTS } \\
\hline \multicolumn{8}{|l|}{ NONSTRUCTURAL COSTS } \\
\hline \multicolumn{8}{|l|}{ FINISHING COSTS } \\
\hline \multicolumn{8}{|l|}{ PROJECT COSTS } \\
\hline \multicolumn{8}{|l|}{ SOURCE OF COST ESTIMATE } \\
\hline COMMENTS & & & & & & & \\
\hline
\end{tabular}


ORNL NON-EXEMPT, NON-EVALUATED BUILDINGS, SORTED BY MODEL BUILDING TYPE AND BUILDING NUMBER

\begin{tabular}{|c|c|c|c|c|c|c|c|}
\hline AGENCY CODE & 8900 & 8900 & 8900 & 8900 & 8900 & 8900 & 8900 \\
\hline UNIQUE IDENTIFIER & 3504 & 3505 & 3512 & 4502 & $5500 A$ & 2012 & 2500 \\
\hline STATE CODE & 47 & 47 & 47 & 47 & 47 & 47 & 47 \\
\hline COUNTY CODE & 001 & 001 & 001 & 001 & 001 & $\infty 01$ & 001 \\
\hline SEISMICITY & $\mathbf{M}$ & $M$ & $\mathbf{M}$ & $\mathbf{M}$ & $\mathbf{M}$ & $\mathbf{M}$ & $M$ \\
\hline AREA, $\mathrm{m}^{2}$ & 680 & 609 & 1552 & 736 & 743 & 2496 & 1364 \\
\hline NUMBER OF BUILDINGS & 1 & 1 & 1 & 1 & 1 & 1 & 1 \\
\hline EXEMPTION CRITERIA & E0 & E0 & E0 & E0 & E0 & E0 & E0 \\
\hline OCCUPANCY CLASS & 70 & 50 & 70 & 50 & 10 & 50 & 70 \\
\hline ESSENTIAL DESIGNATION & $\mathbf{P I}$ & P1 & P3 & P1 & P1 & P1 & $\mathbf{P 2}$ \\
\hline HISTORIC DESIGNATION & $\mathrm{H} 2$ & $\mathrm{H} 2$ & $\mathbf{H 2}$ & $\mathrm{H} 2$ & $\mathrm{H} 2$ & $\mathrm{H2}$ & $\mathrm{H} 2$ \\
\hline DATE OF CONSTRUCTION & 1951 & 1951 & 1958 & 1968 & 1968 & 1953 & 1952 \\
\hline MODEL BUILDING TYPE & MB04 & $\mathrm{MBO4}$ & $\mathrm{MBO4}$ & $\mathrm{MBO4}$ & MB04 & MB04 & MB04 \\
\hline NUMBER OF STORIES & N02 & N01 & N01 & N01 & N01 & N01 & N01 \\
\hline \multicolumn{8}{|l|}{ EHR DESIGNATION } \\
\hline \multicolumn{8}{|c|}{ EVALUATION PROCEDURE USED } \\
\hline \multicolumn{8}{|l|}{ SOIL TYPE } \\
\hline \multicolumn{8}{|l|}{ FOUNDATION TYPE } \\
\hline \multicolumn{8}{|l|}{ OUTCOME OF EVALUATON } \\
\hline \multicolumn{8}{|c|}{ STRUCTURAL DEFCIENCY DETERMINATION } \\
\hline \multicolumn{8}{|c|}{ NONSTRUCTURAL DEFCIENCY DETERMINATION } \\
\hline \multicolumn{8}{|c|}{ GEOLOGIC/SITE HAZARD DEFICIENCY DETERMINATION } \\
\hline \multicolumn{8}{|c|}{ ADJACENCY PROBLEM DETERMINATION } \\
\hline \multicolumn{8}{|c|}{ STRUCTURAL COSTS } \\
\hline \multicolumn{8}{|l|}{ NONSTRUCTURAL COSTS } \\
\hline \multicolumn{8}{|l|}{ FINISHING COSTS } \\
\hline \multicolumn{8}{|l|}{ PROJECT COSTS } \\
\hline \multicolumn{8}{|l|}{ SOURCE OF COST ESTIMATE } \\
\hline COMMENTS & & & & & & & \\
\hline
\end{tabular}


ORNL NON-EXEMPT, NON-EVALUATED BUILDINGS, SORTED BY MODEL BUILDING TYPE AND BUILDING NUMBER

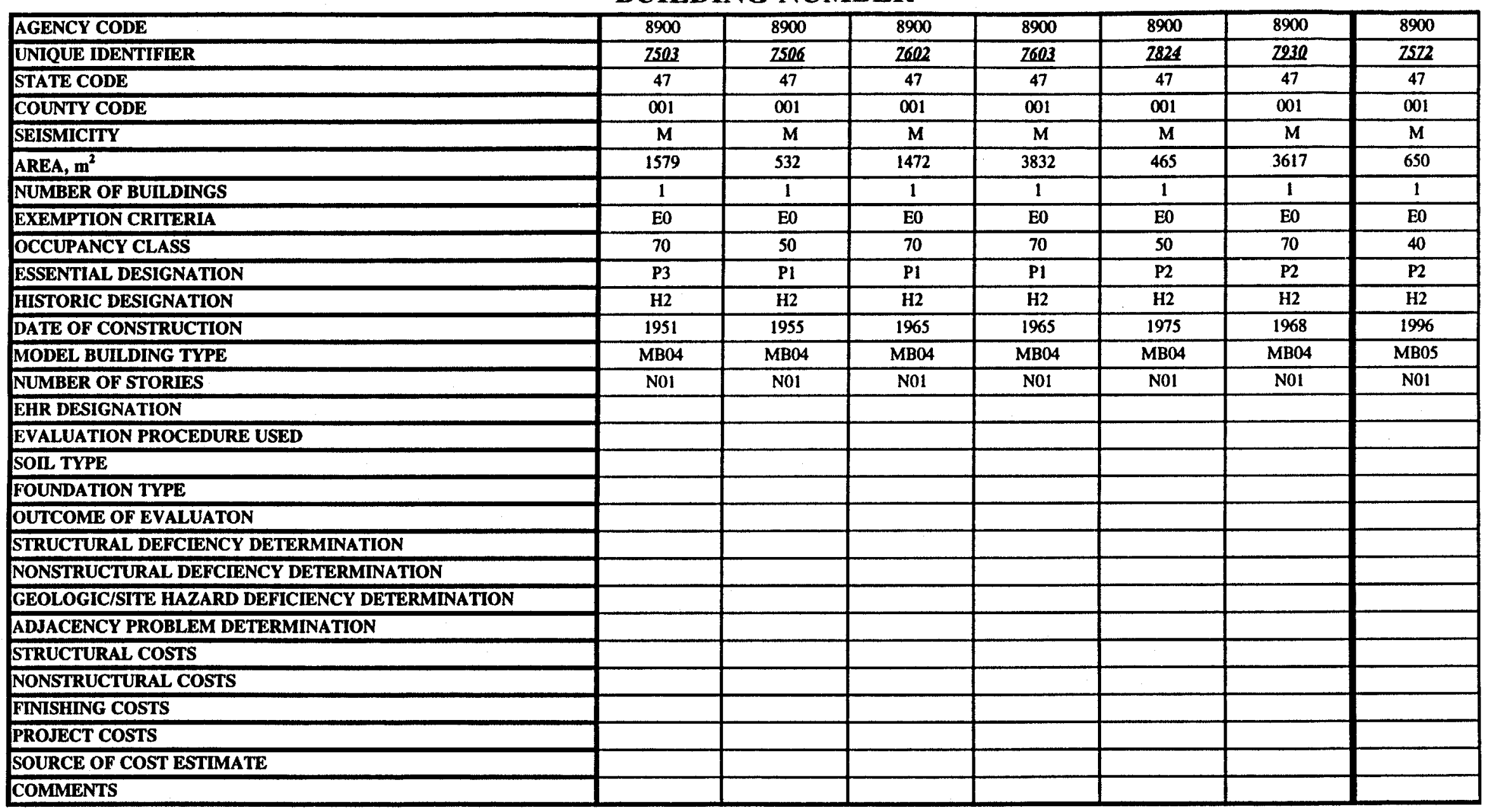


ORNL NON-EXEMPT, NON-EVALUATED BUILDINGS, SORTED BY MODEL BUILDING TYPE AND BUILDING NUMBER

\begin{tabular}{|c|c|c|c|c|c|c|c|}
\hline AGENCY CODE & 8900 & 8900 & 8900 & 8900 & 8900 & 8900 & 8900 \\
\hline UNIQUE IDENTIFIER & 2574 & 2668 & Z842 & 2960 & 2542 & 2072 & 2502 \\
\hline STATE CODE & 47 & 47 & 47 & 47 & 47 & 47 & 47 \\
\hline COUNTY CODE & 001 & 001 & 001 & 001 & 001 & 001 & 001 \\
\hline SEISMICITY & $\mathbf{M}$ & $\mathbf{M}$ & $\mathbf{M}$ & $M$ & $\mathbf{M}$ & $\mathbf{M}$ & $M$ \\
\hline AREA, $\mathbf{m}^{2}$ & 372 & 338 & 595 & 149 & 876 & 401 & 136 \\
\hline NUMBER OF BUILDINGS & 1 & 1 & 1 & 1 & 1 & 1 & 1 \\
\hline EXEMPTION CRITERIA & EO & EO & E0 & EO & E0 & EO & E0 \\
\hline OCCUPANCY CLASS & 40 & 40 & 40 & 40 & 50 & 50 & 60 \\
\hline ESSENTIAL DESIGNATION & P3 & P3 & $\mathbf{P 2}$ & P3 & P1 & P1 & P3 \\
\hline HISTORIC DESIGNATION & H2 & $\mathrm{H2}$ & $\mathbf{H 2}$ & $\mathbf{H 2}$ & $\mathrm{H} 2$ & $\mathrm{H} 2$ & $\mathrm{H} 2$ \\
\hline DATE OF CONSTRUCTION & 1992 & 1989 & 1983 & 1988 & 1987 & 1990 & 1961 \\
\hline MODEL BUILDING TYPE & MB05 & MB05 & MB05 & MB05 & MB05 & MB0S & MB0S \\
\hline NUMBER OF STORIES & N01 & N01 & N01 & N01 & No1 & N01 & N01 \\
\hline \multicolumn{8}{|l|}{ EHR DESIGNATION } \\
\hline \multicolumn{8}{|c|}{ EVALUATION PROCEDURE USED } \\
\hline \multicolumn{8}{|l|}{ SOL TYPE } \\
\hline \multicolumn{8}{|l|}{ FOUNDATION TYPE } \\
\hline \multicolumn{8}{|l|}{ OUTCOME OF EVALUATON } \\
\hline \multicolumn{8}{|c|}{ STRUCTURAL DEFCIENCY DETERMINATION } \\
\hline \multicolumn{8}{|c|}{ NONSTRUCTURAL DEFCIENCY DETERMINATION } \\
\hline \multicolumn{8}{|c|}{ GEOLOGIC/SITE HAZARD DEFICIENCY DETERMINATION } \\
\hline \multicolumn{8}{|c|}{ ADJACENCY PROBLEM DETERMINATION } \\
\hline \multicolumn{8}{|l|}{ STRUCTURAL COSTS } \\
\hline \multicolumn{8}{|l|}{ NONSTRUCTURAL COSTS } \\
\hline \multicolumn{8}{|l|}{ FINISHING COSTS } \\
\hline \multicolumn{8}{|l|}{ PROJECT COSTS } \\
\hline \multicolumn{8}{|l|}{ SOURCE OF COST ESTIMATE } \\
\hline COMMENTS & & & & & & & \\
\hline
\end{tabular}

D - 12 
ORNL NON-EXEMPT, NON-EVALUATED BUILDINGS, SORTED BY MODEL BUILDING TYPE AND BUILDING NUMBER

\begin{tabular}{|c|c|c|c|c|c|c|c|}
\hline AGENCY CODE & 8900 & 8900 & 8900 & 8900 & 8900 & 8900 & 8900 \\
\hline UNIQUE IDENTIFIER & $2507 \mathrm{~W}$ & 2872 & 2912 & 7234 & $3025 E$ & $3025 \mathrm{~W}$ & 4505 \\
\hline STATE CODE & 47 & 47 & 47 & 47 & 47 & 47 & 47 \\
\hline COUNTY CODE & 001 & 001 & 001 & 001 & 001 & 001 & 001 \\
\hline SEISMICITY & $\mathbf{M}$ & $\mathbf{M}$ & $M$ & $\mathbf{M}$ & $\mathrm{M}$ & $\mathbf{M}$ & M \\
\hline AREA, $\mathbf{m}^{2}$ & 209 & 32 & 738 & 232 & 5489 & 5489 & 7289 \\
\hline NUMBER OF BUILDINGS & 1 & 1 & 1 & 1 & 1 & 1 & 1 \\
\hline EXEMPTION CRITERIA & E0 & EO & E0 & E0 & EO & E0 & E0 \\
\hline OCCUPANCY CLASS & 40 & 40 & 10 & 40 & 70 & 70 & 70 \\
\hline ESSENTIAL DESIGNATION & P2 & $\mathbf{P 2}$ & $\mathbf{P 1}$ & P2 & $\mathbf{P 2}$ & P1 & P1 \\
\hline HISTORIC DESIGNATION & $\mathrm{H} 2$ & $\mathrm{H} 2$ & $\mathrm{H} 2$ & $\mathrm{H} 2$ & $\mathrm{H} 2$ & $\mathrm{H} 2$ & H2 \\
\hline DATE OF CONSTRUCTION & 1993 & 1987 & 1990 & 1984 & 1950 & 1950 & 1951 \\
\hline MODEL BUILDING TYPE & MB05 & MB05 & MB05 & MB05 & MB07 & MB07 & MB07 \\
\hline NUMBER OF STORIES & Nol & N01 & N02 & N01 & N03 & N03 & N03 \\
\hline \multicolumn{8}{|l|}{ EHR DESIGNATION } \\
\hline \multicolumn{8}{|c|}{ EVALUATION PROCEDURE USED } \\
\hline \multicolumn{8}{|l|}{ SOIL TYPE } \\
\hline \multicolumn{8}{|l|}{ FOUNDATION TYPE } \\
\hline \multicolumn{8}{|l|}{ OUTCOME OF EVALUATON } \\
\hline \multicolumn{8}{|c|}{ STRUCTURAL DEFCIENCY DETERMINATION } \\
\hline \multicolumn{8}{|c|}{ NONSTRUCTURAL DEFCIENCY DETERMINATION } \\
\hline \multicolumn{8}{|c|}{ GEOLOGIC/SITE HAZARD DEFICIENCY DETERMINATION } \\
\hline \multicolumn{8}{|c|}{ ADJACENCY PROBLEM DETERMINATION } \\
\hline \multicolumn{8}{|l|}{ STRUCTURAL COSTS } \\
\hline \multicolumn{8}{|l|}{ NONSTRUCTURAL COSTS } \\
\hline \multicolumn{8}{|l|}{ FINISHING COSTS } \\
\hline \multicolumn{8}{|l|}{ PROJECT COSTS } \\
\hline \multicolumn{8}{|l|}{ SOURCE OF COST ESTIMATE } \\
\hline COMMENTS & & & & & & & \\
\hline
\end{tabular}


ORNL NON-EXEMPT, NON-EVALUATED BUILDINGS, SORTED BY MODEL BUILDING TYPE AND BUILDING NUMBER

\begin{tabular}{|c|c|c|c|c|c|c|c|}
\hline AGENCY CODE & 8900 & 8900 & 8900 & 8900 & 8900 & 8900 & 8900 \\
\hline UNIQUE IDENTIFIER & 4502 & 2010 & 2026 & 3500 & 4501 & 4508 & 4515 \\
\hline STATE CODE & 47 & 47 & 47 & 47 & 47 & 47 & 47 \\
\hline COUNTY CODE & 001 & $\infty 01$ & 001 & 001 & 001 & 001 & 001 \\
\hline SEISMICITY & $\mathbf{M}$ & $\mathrm{M}$ & $\mathbf{M}$ & $\mathbf{M}$ & $\mathbf{M}$ & $\mathbf{M}$ & $\mathbf{M}$ \\
\hline AREA, $\mathrm{m}^{2}$ & 354 & 1093 & 2583 & 7385 & 3367 & 9200 & 5992 \\
\hline NUMBER OF BUILDINGS & 1 & 1 & 1 & 1 & 1 & 1 & 1 \\
\hline EXEMPTION CRITERIA & E0 & E0 & E0 & E0 & E0 & E0 & E0 \\
\hline OCCUPANCY CLASS & 70 & 60 & 70 & 70 & 70 & 70 & 70 \\
\hline ESSENTIAL DESIGNATION & P1 & $\mathrm{Pl}$ & P2 & $\mathrm{PI}$ & $\mathbf{P 2}$ & P1 & P1 \\
\hline HISTORIC DESIGNATION & $\mathrm{H2}$ & $\mathrm{H} 2$ & $\mathrm{H} 2$ & $\mathrm{H} 2$ & $\mathrm{H} 2$ & $\mathrm{H} 2$ & $\mathrm{H} 2$ \\
\hline DATE OF CONSTRUCTION & 1957 & 1951 & 1964 & 1951 & 1951 & 1962 & 1987 \\
\hline MODEL BUILDING TYPE & MB07 & MB08 & MB08 & MB08 & MB08 & MB08 & MB08 \\
\hline NUMBER OF STORIES & N01 & N01 & N02 & N02 & N02 & N02 & $\mathrm{N} 02$ \\
\hline \multicolumn{8}{|l|}{ EHR DESIGNATION } \\
\hline \multicolumn{8}{|c|}{ EVALUATION PROCEDURE USED } \\
\hline \multicolumn{8}{|l|}{ SOIL TYPE } \\
\hline \multicolumn{8}{|l|}{ FOUNDATION TYPE } \\
\hline \multicolumn{8}{|l|}{ OUTCOME OF EVALUATON } \\
\hline \multicolumn{8}{|c|}{ STRUCTURAL DEFCIENCY DETERMINATION } \\
\hline \multicolumn{8}{|c|}{ NONSTRUCTURAL DEFCIENCY DETERMINATION } \\
\hline \multicolumn{8}{|c|}{ GEOLOGIC/SITE HAZARD DEFICIENCY DETERMINATION } \\
\hline \multicolumn{8}{|c|}{ ADJACENCY PROBLEM DETERMINATION } \\
\hline \multicolumn{8}{|l|}{ STRUCTURAL COSTS } \\
\hline \multicolumn{8}{|l|}{ NONSTRUCTURAL COSTS } \\
\hline \multicolumn{8}{|l|}{ FINISHING COSTS } \\
\hline \multicolumn{8}{|l|}{ PROJECT COSTS } \\
\hline \multicolumn{8}{|l|}{ SOURCE OF COST ESTIMATE } \\
\hline COMMENTS & & & & & & & \\
\hline
\end{tabular}

D -14 
ORNL NON-EXEMPT, NON-EVALUATED BUILDINGS, SORTED BY MODEL BUILDING TYPE AND BUILDING NUMBER

\begin{tabular}{|c|c|c|c|c|c|c|c|}
\hline AGENCY CODE & 8900 & 8900 & 8900 & 8900 & 8900 & 8900 & 8900 \\
\hline UNIQUE IDENTIFIER & 3130 & 2649 & 3002 & 3027 & 2702 & 2860 & 7883 \\
\hline STATE CODE & 47 & 47 & 47 & 47 & 47 & 47 & 47 \\
\hline COUNTY CODE & 001 & 001 & 001 & 001 & 001 & 001 & 001 \\
\hline SEISMICITY & $M$ & $M$ & $\mathbf{M}$ & $\mathbf{M}$ & $\mathbf{M}$ & $\mathbf{M}$ & $\mathbf{M}$ \\
\hline AREA, $\mathrm{m}^{2}$ & 381 & 698 & 321 & 357 & 1186 & 383 & 426 \\
\hline NUMBER OF BUILDINGS & 1 & 1 & 1 & 1 & 1 & 1 & 1 \\
\hline EXEMPTION CRITERIA & E0 & E0 & E0 & E0 & E0 & E0 & E0 \\
\hline OCCUPANCY CLASS & 50 & 70 & 50 & 40 & 50 & 70 & 40 \\
\hline ESSENTIAL DESIGNATION & P1 & $\mathbf{P 2}$ & $\mathbf{P 2}$ & P3 & P1 & P1 & P3 \\
\hline HISTORIC DESIGNATION & $\mathrm{H} 2$ & H2 & $\mathrm{H} 2$ & $\mathrm{H} 2$ & $\mathbf{H} 2$ & $\mathrm{H} 2$ & $\mathrm{H} 2$ \\
\hline DATE OF CONSTRUCTION & 1983 & 1996 & 1948 & 1955 & 1954 & 1980 & 1989 \\
\hline MODEL BUILDING TYPE & MB09 & MB09 & MB09 & MB09 & MB09 & MB09 & MB09 \\
\hline NUMBER OF STORIES & $\mathrm{N02}$ & N01 & N01 & N01 & N01 & N01 & N01 \\
\hline \multicolumn{8}{|l|}{ EHR DESIGNATION } \\
\hline \multicolumn{8}{|c|}{ EVALUATION PROCEDURE USED } \\
\hline \multicolumn{8}{|l|}{ SOIL TYPE } \\
\hline \multicolumn{8}{|l|}{ FOUNDATION TYPE } \\
\hline \multicolumn{8}{|l|}{ OUTCOME OF EVALUATON } \\
\hline \multicolumn{8}{|c|}{ STRUCTURAL DEFCIENCY DETERMINATION } \\
\hline \multicolumn{8}{|c|}{ NONSTRUCTURAL DEFCIENCY DETERMINATION } \\
\hline \multicolumn{8}{|c|}{ GEOLOGIC/SITE HAZARD DEFICIENCY DETERMINATION } \\
\hline \multicolumn{8}{|c|}{ ADJACENCY PROBLEM DETERMINATION } \\
\hline \multicolumn{8}{|l|}{ STRUCTURAL COSTS } \\
\hline \multicolumn{8}{|l|}{ NONSTRUCTURAL COSTS } \\
\hline \multicolumn{8}{|l|}{ FINISHING COSTS } \\
\hline \multicolumn{8}{|l|}{ PROJECT COSTS } \\
\hline \multicolumn{8}{|l|}{ SOURCE OF COST ESTIMATE } \\
\hline COMMENTS & & & & & & & \\
\hline
\end{tabular}


ORNL NON-EXEMPT, NON-EVALUATED BUILDINGS, SORTED BY MODEL BUILDING TYPE AND BUILDING NUMBER

\begin{tabular}{|c|c|c|c|c|c|c|c|}
\hline AGENCY CODE & 8900 & 8900 & 8900 & 8900 & 8900 & 8900 & 8900 \\
\hline UNIQUE IDENTIFIER & 2900 & 1505 & 2002 & 2519 & 3546 & 3606 & 5505 \\
\hline STATE CODE & 47 & 47 & 47 & 47 & 47 & 47 & 47 \\
\hline COUNTY CODE & 001 & 001 & 001 & 001 & 001 & 001 & 001 \\
\hline SEISMICITY & $\mathbf{M}$ & $\mathbf{M}$ & $\mathbf{M}$ & $\mathbf{M}$ & $\mathbf{M}$ & $\mathbf{M}$ & $M$ \\
\hline AREA, $\mathbf{m}^{2}$ & 5738 & 9098 & 44 & 2194 & 680 & 697 & 2160 \\
\hline NUMBER OF BUILDINGS & 1 & 1 & 1 & 1 & 1 & 1 & 1 \\
\hline EXEMPTION CRITERIA & E0 & E0 & E0 & E0 & E0 & EO & E0 \\
\hline OCCUPANCY CLASS & 70 & 70 & 50 & 50 & 10 & 10 & 70 \\
\hline ESSENTIAL DESIGNATION & P3 & PI & $\mathbf{P 2}$ & P1 & P1 & P1 & $\mathrm{P} 2$ \\
\hline HISTORIC DESIGNATION & $\mathrm{H} 2$ & $\mathrm{H} 2$ & $\mathrm{H} 2$ & $\mathrm{H} 2$ & $\mathrm{H2}$ & H2 & $\mathrm{H} 2$ \\
\hline DATE OF CONSTRUCTION & 1965 & 1978 & 1993 & 1948 & 1976 & 1985 & 1968 \\
\hline MODEL BUILDING TYPE & MB09 & MB10 & MB10 & MB10 & MBio & MB10 & MB10 \\
\hline NUMBER OF STORIES & N01 & N03 & N01 & N04 & N01 & N02 & N01 \\
\hline \multicolumn{8}{|l|}{ EHR DESIGNATION } \\
\hline \multicolumn{8}{|c|}{ EVALUATION PROCEDURE USED } \\
\hline \multicolumn{8}{|l|}{ SOIL TYPE } \\
\hline \multicolumn{8}{|l|}{ FOUNDATION TYPE } \\
\hline \multicolumn{8}{|l|}{ OUTCOME OF EVALUATON } \\
\hline \multicolumn{8}{|c|}{ STRUCTURAL DEFCIENCY DETERMINATION } \\
\hline \multicolumn{8}{|c|}{ NONSTRUCTURAL DEFCIENCY DETERMINATION } \\
\hline \multicolumn{8}{|c|}{ GEOLOGIC/SITE HAZARD DEFICIENCY DETERMINATION } \\
\hline \multicolumn{8}{|c|}{ ADJACENCY PROBLEM DETERMINATION } \\
\hline \multicolumn{8}{|l|}{ STRUCTURAL COSTS } \\
\hline \multicolumn{8}{|l|}{ NONSTRUCTURAL COSTS } \\
\hline \multicolumn{8}{|l|}{ FINISHING COSTS } \\
\hline \multicolumn{8}{|l|}{ PROJECT COSTS } \\
\hline \multicolumn{8}{|l|}{ SOURCE OF COST ESTIMATE } \\
\hline COMMENTS & & & & & & & \\
\hline
\end{tabular}


ORNL NON-EXEMPT, NON-EVALUATED BUILDINGS, SORTED BY MODEL BUILDING TYPE AND BUILDING NUMBER

\begin{tabular}{|c|c|c|c|c|c|c|c|}
\hline AGENCY CODE & 8900 & 8900 & 8900 & 8900 & 8900 & 8900 & 8900 \\
\hline UNIQUE IDENTIFIER & 6000 & 7601 & 2007 & 2531 & 2638 & 3017 & 4512 \\
\hline STATE CODE & 47 & 47 & 47 & 47 & 47 & 47 & 47 \\
\hline COUNTY CODE & 001 & 001 & 001 & 001 & 001 & 001 & 001 \\
\hline SEISMICITY & $\mathbf{M}$ & $\mathbf{M}$ & $M$ & $\mathbf{M}$ & $M$ & $\mathbf{M}$ & $\mathbf{M}$ \\
\hline AREA, $\mathrm{m}^{2}$ & 10201 & 1799 & 811 & 836 & 59 & 952 & 455 \\
\hline NUMBER OF BUILDINGS & 1 & 1 & 1 & 1 & 1 & 1 & 1 \\
\hline EXEMPTION CRITERIA & E0 & E0 & E0 & E0 & E0 & E0 & EO \\
\hline OCCUPANCY CLASS & 70 & 10 & 70 & 50 & 50 & 10 & 29 \\
\hline ESSENTIAL DESIGNATION & P1 & P1 & $\mathrm{PI}$ & P3 & $\mathbf{P 1}$ & P1 & $\mathbf{P 2}$ \\
\hline HISTORIC DESIGNATION & $\mathrm{H} 2$ & $\mathrm{H} 2$ & $\mathrm{H} 2$ & $\mathrm{H2}$ & $\mathrm{H2}$ & H2 & $\mathrm{H2}$ \\
\hline DATE OF CONSTRUCTION & 1961 & 1965 & 1951 & 1954 & 1978 & 1952 & 1987 \\
\hline MODEL BUILDING TYPE & MB10 & MB10 & MB13 & MB13 & MB13 & MB13 & MB13 \\
\hline NUMBER OF STORIES & N01 & N02 & N01 & N01 & N01 & N01 & N01 \\
\hline \multicolumn{8}{|l|}{ EHR DESIGNATION } \\
\hline \multicolumn{8}{|c|}{ EVALUATION PROCEDURE USED } \\
\hline \multicolumn{8}{|l|}{ SOIL TYPE } \\
\hline \multicolumn{8}{|l|}{ FOUNDATION TYPE } \\
\hline \multicolumn{8}{|l|}{ OUTCOME OF EVALUATON } \\
\hline \multicolumn{8}{|c|}{ STRUCTURAL DEFCIENCY DETERMINATION } \\
\hline \multicolumn{8}{|c|}{ NONSTRUCTURAL DEFCIENCY DETERMINATION } \\
\hline \multicolumn{8}{|c|}{ GEOLOGIC/SITE HAZARD DEFICIENCY DETERMINATION } \\
\hline \multicolumn{8}{|c|}{ ADJACENCY PROBLEM DETERMINATION } \\
\hline \multicolumn{8}{|l|}{ STRUCTURAL COSTS } \\
\hline \multicolumn{8}{|l|}{ NONSTRUCTURAL COSTS } \\
\hline \multicolumn{8}{|l|}{ FINISHING COSTS } \\
\hline \multicolumn{8}{|l|}{ PROJECT COSTS } \\
\hline \multicolumn{8}{|l|}{ SOURCE OF COST ESTIMATE } \\
\hline COMMENTS & & & & & & & \\
\hline
\end{tabular}




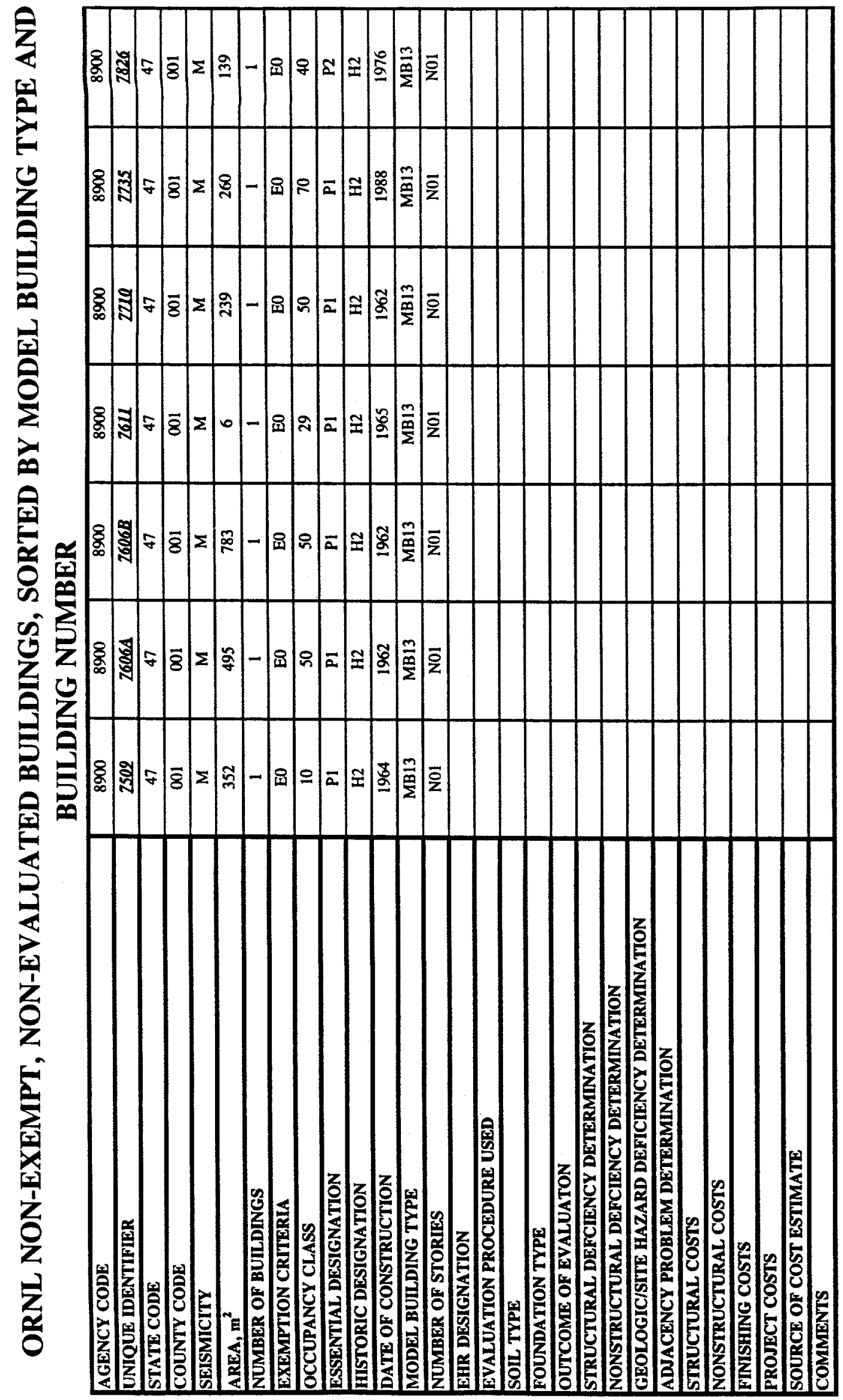


ORNL NON-EXEMPT, NON-EVALUATED BUILDINGS, SORTED BY MODEL BUILDING TYPE AND BUILDING NUMBER

\begin{tabular}{|c|c|c|c|c|c|c|c|}
\hline AGENCY CODE & 8900 & 8900 & 8900 & 8900 & 8900 & 8900 & 8900 \\
\hline UNIQUE IDENTIFIER & 2910 & 2932 & 2500 & 2518 & 2525 & 6007 & 6008 \\
\hline STATE CODE & 47 & 47 & 47 & 47 & 47 & 47 & 47 \\
\hline COUNTY CODE & 001 & 001 & 001 & 001 & 001 & 001 & 001 \\
\hline SEISMICITY & $\mathbf{M}$ & $M$ & $\mathbf{M}$ & $\mathbf{M}$ & $\mathbf{M}$ & $\mathbf{M}$ & $\mathbf{M}$ \\
\hline AREA, $\mathrm{m}^{2}$ & 1230 & 14 & 804 & 941 & 2566 & 362 & 557 \\
\hline NUMBER OF BUILDINGS & 1 & $T$ & 1 & 1 & 1 & 1 & 1 \\
\hline EXEMPTION CRITERIA & EO & EO & E0 & E0 & E0 & E0 & E0 \\
\hline OCCUPANCY CLASS & 10 & 50 & 60 & 10 & 50 & 10 & 70 \\
\hline ESSENTIAL DESIGNATION & PI & $\mathbf{P 2}$ & $\mathbf{P 1}$ & P1 & P1 & P1 & P1 \\
\hline HISTORIC DESIGNATION & $\mathrm{H} 2$ & $\mathrm{H} 2$ & $\mathrm{H} 2$ & $\mathrm{H} 2$ & $\mathrm{H} 2$ & $\mathrm{H2}$ & $\mathrm{H} 2$ \\
\hline DATE OF CONSTRUCTION & 1965 & 1968 & 1967 & 1951 & 1957 & 1983 & 1984 \\
\hline MODEL BUILDING TYPE & MB13 & MB13 & MB14 & MB14 & MB14 & MB14 & MB14 \\
\hline NUMBER OF STORIES & N01 & N01 & No1 & N01 & N01 & No1 & N01 \\
\hline \multicolumn{8}{|l|}{ EHR DESIGNATION } \\
\hline \multicolumn{8}{|c|}{ EVALUATION PROCEDURE USED } \\
\hline \multicolumn{8}{|l|}{ SOIL TYPE } \\
\hline \multicolumn{8}{|l|}{ FOUNDATION TYPE } \\
\hline \multicolumn{8}{|l|}{ OUTCOME OF EVALUATON } \\
\hline \multicolumn{8}{|c|}{ STRUCTURAL DEFCIENCY DETERMINATION } \\
\hline \multicolumn{8}{|c|}{ NONSTRUCTURAL DEFCIENCY DETERMINATION } \\
\hline \multicolumn{8}{|c|}{ GEOLOGIC/SITE HAZARD DEFICIENCY DETERMINATION } \\
\hline \multicolumn{8}{|c|}{ ADJACENCY PROBLEM DETERMINATION } \\
\hline \multicolumn{8}{|l|}{ STRUCTURAL COSTS } \\
\hline \multicolumn{8}{|l|}{ NONSTRUCTURAL COSTS } \\
\hline \multicolumn{8}{|l|}{ FINISHING COSTS } \\
\hline \multicolumn{8}{|l|}{ PROJECT COSTS } \\
\hline \multicolumn{8}{|l|}{ SOURCE OF COST ESTIMATE } \\
\hline COMMENTS & & & & & & & \\
\hline
\end{tabular}


ORNL NON-EXEMPT, NON-EVALUATED BUILDINGS, SORTED BY MODEL BUILDING TYPE AND BUILDING NUMBER

\begin{tabular}{|c|c|c|c|c|c|c|c|}
\hline AGENCY CODE & 8900 & 8900 & 8900 & 8900 & 8900 & 8900 & 8900 \\
\hline UNIQUE IDENTIFIER & 2015 & 2067 & 2855 & 2569 & 1504 & 2537 & 3002 \\
\hline STATE CODE & 47 & 47 & 47 & 47 & 47 & 47 & 47 \\
\hline COUNTY CODE & 001 & 001 & 001 & 001 & 001 & 001 & 001 \\
\hline SEISMICITY & $M$ & $\mathbf{M}$ & $M$ & $\mathbf{M}$ & $\mathbf{M}$ & $\mathbf{M}$ & $\mathbf{M}$ \\
\hline AREA, $\mathrm{m}^{2}$ & 199 & 70 & 269 & 7 & 1015 & 28 & 17 \\
\hline NUMBER OF BUILDINGS & 1 & 1 & 1 & 1 & 1 & 1 & 1 \\
\hline EXEMPTION CRITERIA & E0 & E0 & E0 & E0 & E0 & E0 & E0 \\
\hline OCCUPANCY CLASS & 50 & 23 & 40 & 40 & 70 & 50 & 50 \\
\hline ESSENTIAL DESIGNATION & $\mathbf{P 1}$ & P1 & P2 & P3 & P1 & $\mathbf{P 3}$ & $\mathbf{P 2}$ \\
\hline HISTORIC DESIGNATION & $\mathbf{H 2}$ & $\mathrm{H} 2$ & $\mathrm{H2}$ & $\mathrm{H} 2$ & $\mathrm{H} 2$ & $\mathrm{H} 2$ & $\mathrm{H} 2$ \\
\hline DATE OF CONSTRUCTION & 1960 & 1965 & 1988 & 1983 & 1972 & 1978 & 1950 \\
\hline MODEL BUILDING TYPE & MB14 & MB14 & MB14 & MB15 & MB15 & MB15 & $\mathrm{MB15}$ \\
\hline NUMBER OF STORIES & N01 & N01 & No1 & N01 & N01 & N01 & N01 \\
\hline \multicolumn{8}{|l|}{ EHR DESIGNATION } \\
\hline \multicolumn{8}{|c|}{ EVALUATION PROCEDURE USED } \\
\hline \multicolumn{8}{|l|}{ SOIL TYPE } \\
\hline \multicolumn{8}{|l|}{ FOUNDATION TYPE } \\
\hline \multicolumn{8}{|l|}{ OUTCOME OF EVALUATON } \\
\hline \multicolumn{8}{|c|}{ STRUCTURAL DEFCIENCY DETERMINATION } \\
\hline \multicolumn{8}{|c|}{ NONSTRUCTURAL DEFCIENCY DETERMINATION } \\
\hline \multicolumn{8}{|c|}{ GEOLOGIC/SITE HAZARD DEFTCIENCY DETERMINATION } \\
\hline \multicolumn{8}{|c|}{ ADJACENCY PROBLEM DETERMINATION } \\
\hline \multicolumn{8}{|l|}{ STRUCTURAL COSTS } \\
\hline \multicolumn{8}{|l|}{ NONSTRUCTURAL COSTS } \\
\hline \multicolumn{8}{|l|}{ FINISHING COSTS } \\
\hline \multicolumn{8}{|l|}{ PROJECT COSTS } \\
\hline \multicolumn{8}{|l|}{ SOURCE OF COST ESTIMATE } \\
\hline COMMENTS & & & & & & & \\
\hline
\end{tabular}


ORNL NON-EXEMPT, NON-EVALUATED BUILDINGS, SORTED BY MODEL BUILDING TYPE AND BUILDING NUMBER

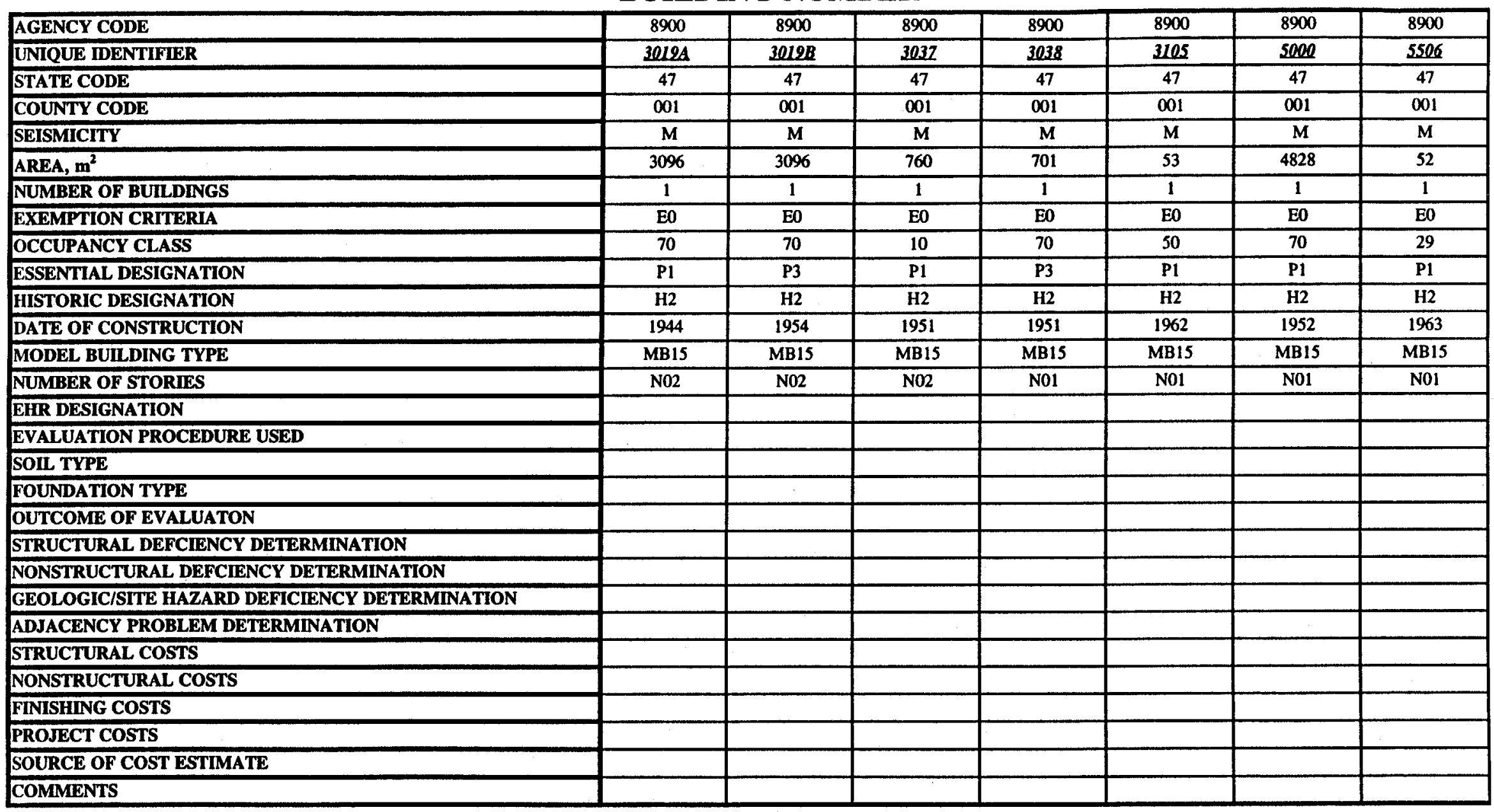


ORNL NON-EXEMPT, NON-EVALUATED BUILDINGS, SORTED BY MODEL BUILDING TYPE AND BUILDING NUMBER

\begin{tabular}{|c|c|c|c|c|c|c|c|}
\hline AGENCY CODE & 8900 & 8900 & 8900 & 8900 & 8900 & 8900 & 8900 \\
\hline UNIQUE IDENTIFIER & $6000 B$ & 6025 & $\mathbf{Z 8 3 0}$ & $Z 834$ & 2567 & 7852 & 2220 \\
\hline STATE CODE & 47 & 47 & 47 & 47 & 47 & 47 & 47 \\
\hline COUNTY CODE & 001 & 001 & 001 & 001 & 001 & 001 & 001 \\
\hline SEISMICITY & $\mathrm{M}$ & $\mathbf{M}$ & $\mathbf{M}$ & $\mathbf{M}$ & $M$ & $\mathbf{M}$ & $M$ \\
\hline AREA, $\mathrm{m}^{2}$ & 474 & 1617 & 56 & 212 & 22 & 14 & 3086 \\
\hline NUMBER OF BUILDINGS & 1 & 1 & 1 & 1 & 1 & 1 & 1 \\
\hline EXEMPTION CRITERIA & E0 & EO & E0 & E0 & E0 & E0 & E0 \\
\hline OCCUPANCY CLASS & 70 & 10 & 40 & 40 & 50 & 50 & 70 \\
\hline ESSENTIAL DESIGNATION & P1 & P1 & P1 & $\mathbf{P 2}$ & P3 & $\mathbf{P 2}$ & $\mathrm{P3}$ \\
\hline HISTORIC DESIGNATION & $\mathrm{H} 2$ & $\mathrm{H2}$ & $\mathrm{H} 2$ & $\mathrm{H} 2$ & $\mathrm{H} 2$ & $\mathrm{H2}$ & $\mathrm{H} 2$ \\
\hline DATE OF CONSTRUCTION & 1995 & 1967 & 1980 & 1980 & 1962 & 1964 & 1966 \\
\hline MODEL BUILDING TYPE & $\mathrm{MB15}$ & MB15 & MB15 & MB15 & MB15 & $\mathrm{MB} 15$ & MB15 \\
\hline NUMBER OF STORIES & N01 & N01 & N01 & N01 & N01 & N01 & N01 \\
\hline \multicolumn{8}{|l|}{ EHR DESIGNATION } \\
\hline \multicolumn{8}{|c|}{ EVALUATION PROCEDURE USED } \\
\hline \multicolumn{8}{|l|}{ SOIL TYPE } \\
\hline \multicolumn{8}{|l|}{ FOUNDATION TYPE } \\
\hline \multicolumn{8}{|l|}{ OUTCOME OF EVALUATON } \\
\hline \multicolumn{8}{|c|}{ STRUCTURAL DEFCIENCY DETERMINATION } \\
\hline \multicolumn{8}{|c|}{ NONSTRUCTURAL DEFCIENCY DETERMINATION } \\
\hline \multicolumn{8}{|c|}{ GEOLOGIC/SITE HAZARD DEFICIENCY DETERMINATION } \\
\hline \multicolumn{8}{|c|}{ ADJACENCY PROBLEM DETERMINATION } \\
\hline \multicolumn{8}{|l|}{ STRUCTURAL COSTS } \\
\hline \multicolumn{8}{|l|}{ NONSTRUCTURAL COSTS } \\
\hline \multicolumn{8}{|l|}{ FINISHING COSTS } \\
\hline \multicolumn{8}{|l|}{ PROJECT COSTS } \\
\hline \multicolumn{8}{|l|}{ SOURCE OF COST ESTIMATE } \\
\hline COMMENTS & & & & & & & \\
\hline
\end{tabular}


ORNL NON-EXEMPT, NON-EVALUATED BUILDINGS, SORTED BY MODEL BUILDING TYPE AND BUILDING NUMBER

\begin{tabular}{|c|c|c|c|}
\hline AGENCY CODE & 8900 & 8900 & 8900 \\
\hline UNIQUE IDENTIFIER & 7231 & 5500 & 6010 \\
\hline STATE CODE & 47 & 47 & 47 \\
\hline COUNTY CODE & 001 & 001 & 001 \\
\hline SEISMICITY & $\mathbf{M}$ & $\mathbf{M}$ & $M$ \\
\hline AREA, $\mathrm{m}^{2}$ & 19 & 4828 & 3883 \\
\hline NUMBER OF BULLDINGS & 1 & 1 & 1 \\
\hline EXEMPTION CRITERIA & E0 & E0 & EO \\
\hline OCCUPANCY CLASS & 50 & 70 & 70 \\
\hline ESSENTIAL DESIGNATION & $\mathbf{P 2}$ & P1 & P1 \\
\hline IISTORIC DESIGNATION & H2 & $\mathrm{H} 2$ & H2 \\
\hline DATE OF CONSTRUCTION & 1968 & 1952 & 1969 \\
\hline MODEL BUILDING TYPE & MB15 & MB16 & MB16 \\
\hline NUMBER OF STORIES & N01 & N02 & N02 \\
\hline \multicolumn{4}{|l|}{ EHR DESIGNATION } \\
\hline \multicolumn{4}{|c|}{ EVALUATION PROCEDURE USED } \\
\hline \multicolumn{4}{|l|}{ SOIL TYPE } \\
\hline \multicolumn{4}{|l|}{ FOUNDATION TYPE } \\
\hline \multicolumn{4}{|l|}{ OUTCOME OF EVALUATON } \\
\hline \multicolumn{4}{|c|}{ STRUCTURAL DEFCIENCY DETERMINATION } \\
\hline \multicolumn{4}{|c|}{ NONSTRUCTURAL DEFCLENCY DETERMINATION } \\
\hline \multicolumn{4}{|c|}{ GEOLOGIC/SITE HAZARD DEFICIENCY DETERMINATION } \\
\hline \multicolumn{4}{|c|}{ ADJACENCY PROBLEM DETERMINATION } \\
\hline \multicolumn{4}{|l|}{ STRUCTURAL COSTS } \\
\hline \multicolumn{4}{|l|}{ NONSTRUCTURAL COSTS } \\
\hline \multicolumn{4}{|l|}{ FINISHING COSTS } \\
\hline \multicolumn{4}{|l|}{ PROJECT COSTS } \\
\hline \multicolumn{4}{|l|}{ SOURCE OF COST ESTIMATE } \\
\hline COMMENTS & & Two Building Systems & Two Building \\
\hline
\end{tabular}




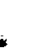




\section{APPENDIX E}

ORNL EVALUATED, NON-EXEMPT BUILDINGS 


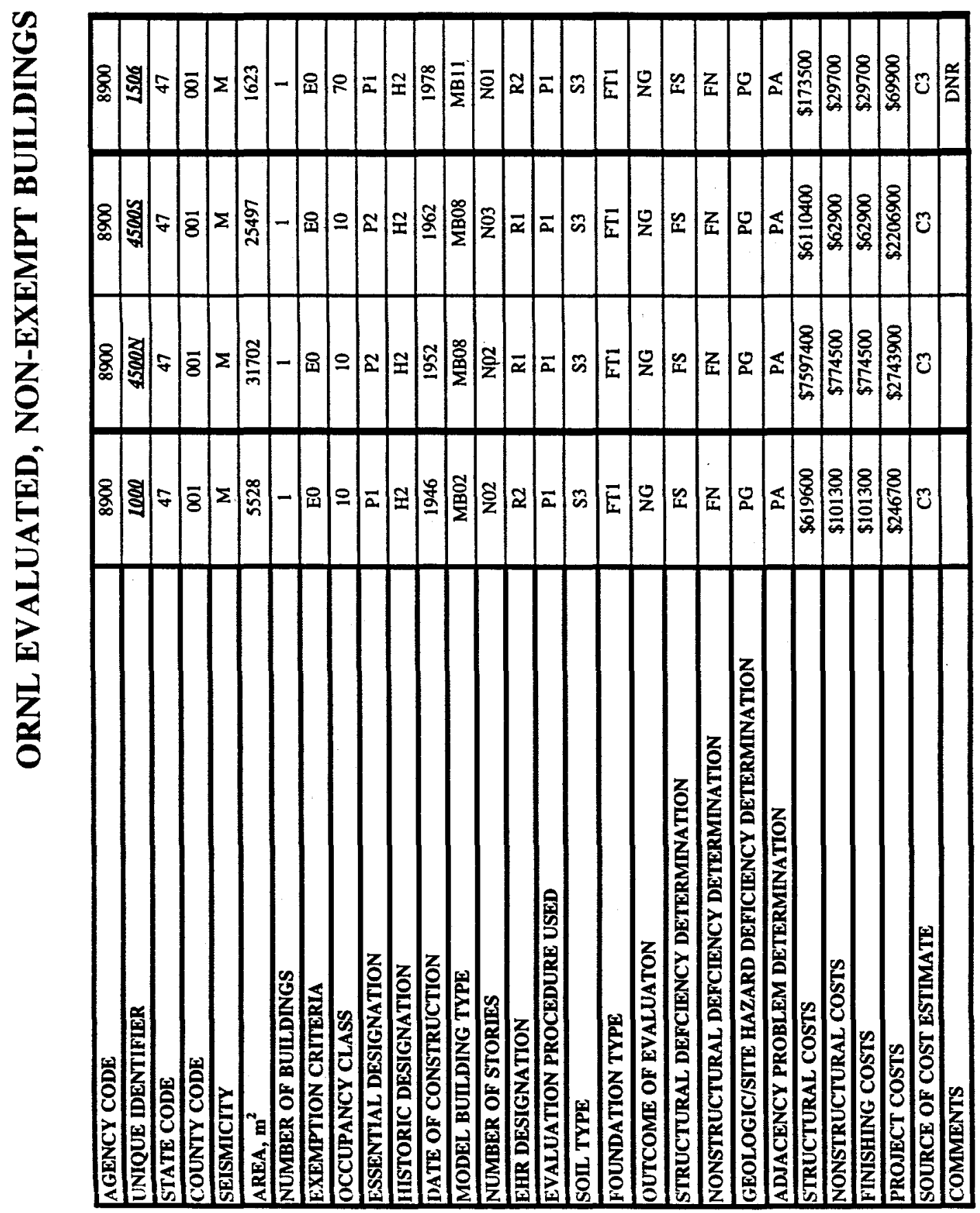


ORNL/M-6145, R1

DISTRIBUTION

1. J. S. Abercrombie

2. R. H. Baldwin

3. C. O. Beasley

4. E. C. Brown

5. R. D. Childs

6. G. E. Courville

7. W. E. Ford

8. D. E. Fowler

9. L. D. Gable

10. D. L. Garner

11. R. K. Genung

12. L. T. Gordon

13. J. W. Hale

14. R. J. Hunt

15. D. N. Keller

16. J. M. Keller

17. M. W. Kohring

18. E. H. Kreig

19. R. J. Kroon

20. D. C. Larson
21. D. C. Larson

22. R. S. McKeehan

23. G. H. Miller

24. S. D. Nolan

25. B. D. Patton

26. L. K. Plemons

27. C. B. Scott

28. K. E. Shaffer

29. M. A. Spann

30. J. H. Swanks

31. R. L. Sy

32. A. W. Trivelpiece - RC

33. C. R. Vane

34. G. D. Watson

35. M. L. Whitehead

36. H. D. Wooten

37. CNPE Library

38. Lab Records

39. ORNL Patent Section 